
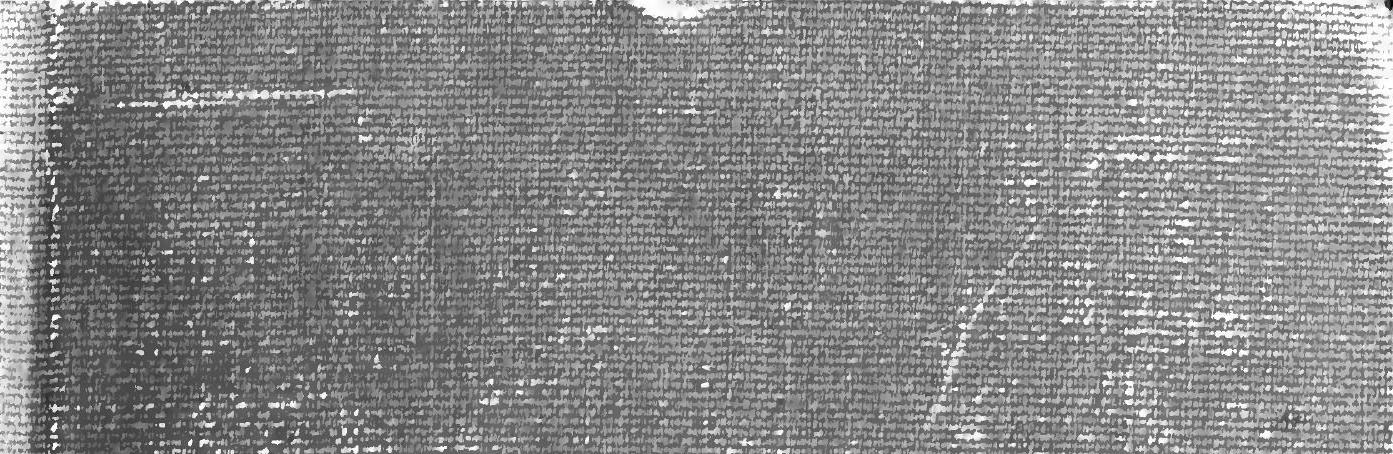

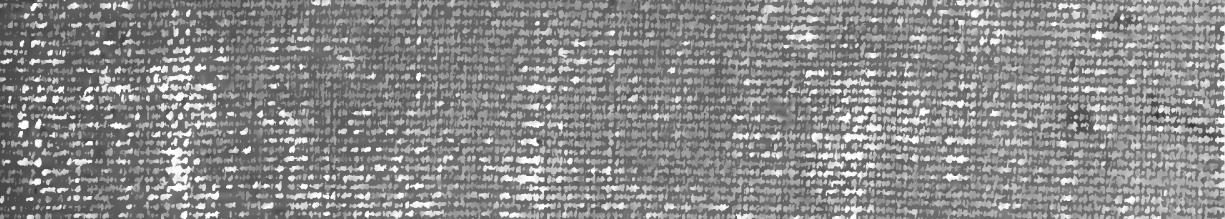

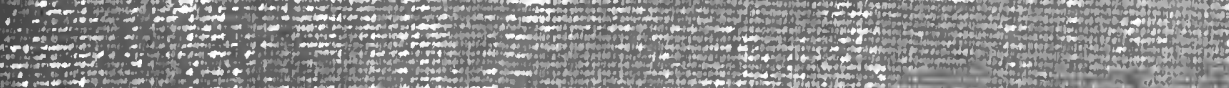

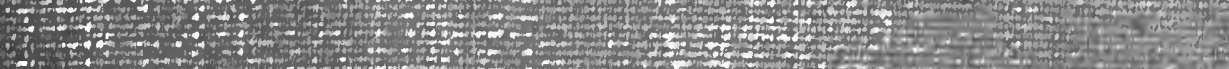

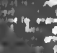

$$
\text { (4. }
$$

sot.

3.t. 

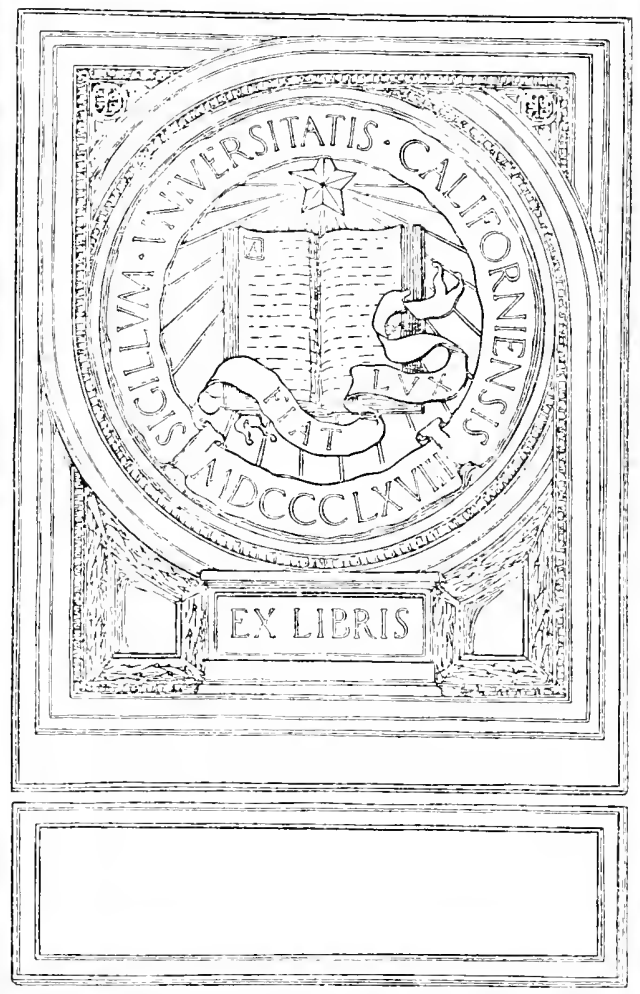


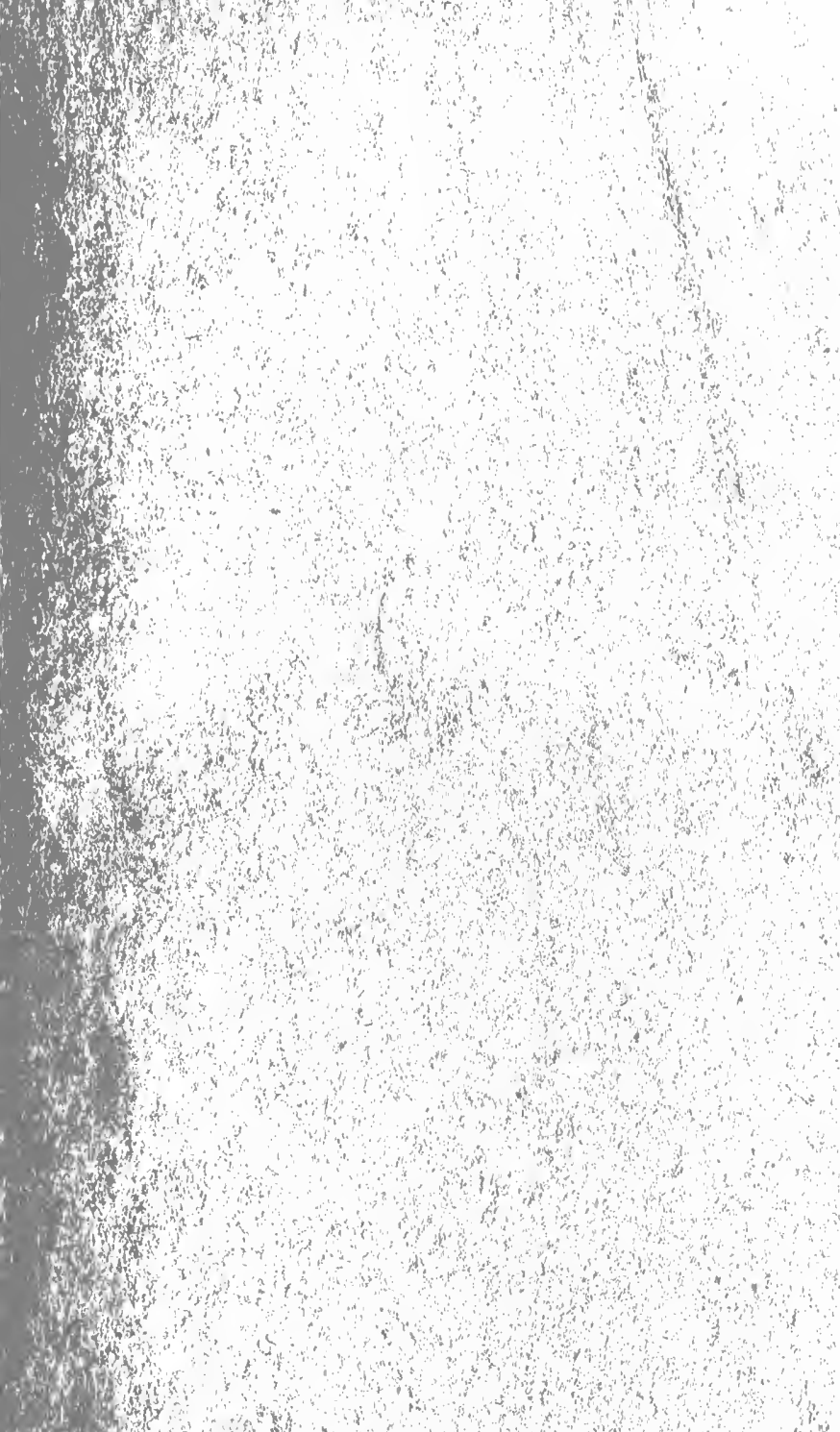




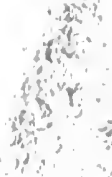

$\therefore \lim ^{2}$

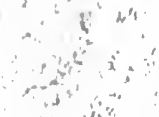

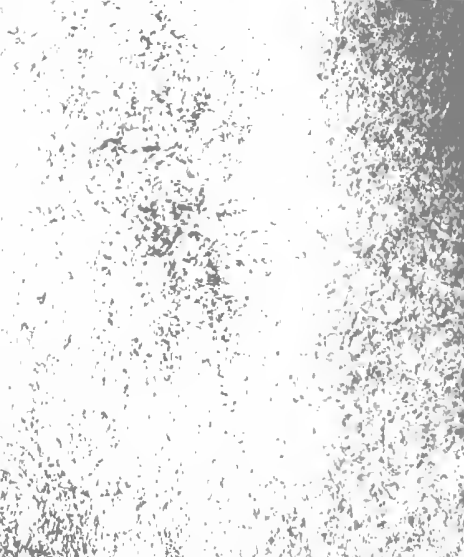

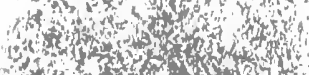

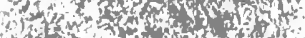
is

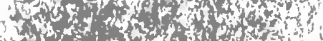

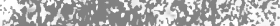

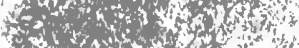

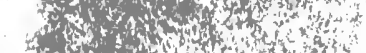

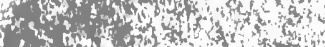

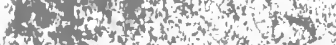
+on-2

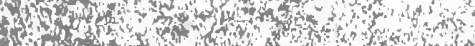

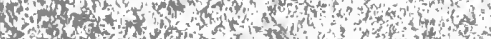

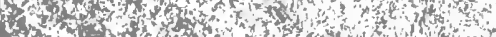

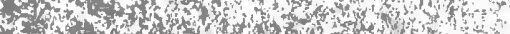

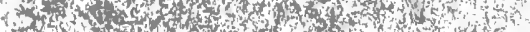

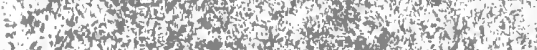

14 at rind 30 .

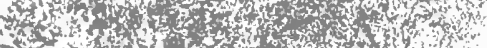

a

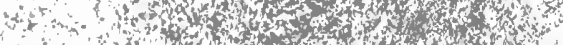

\& 4 :

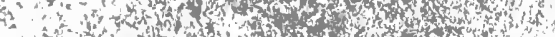

$x$ -

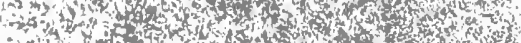

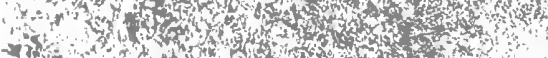

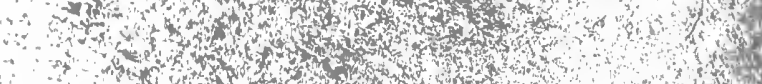

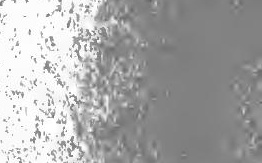

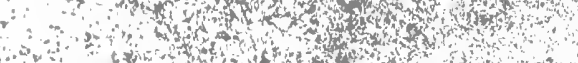

C.

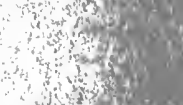

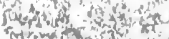

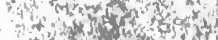

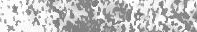
in

ts $x$.

sistoptsen

actors

thing $x+2$

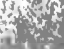

Mx

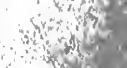




\section{Digitized by the Internet Archive in 2008 with funding from Microsoft Corporation}




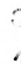




\section{STUDIES IN HISTORY ECONOMICS AND \\ PUBLIC LAW}

EDITED BY

THE FACULTY OF POLITICALS IENCE OF COLUMBIA UNIVERSIT \&

VOLUME TWENTY-SEVENTH

Niew Worli

HE COLUMBIA UNIVERSITY PRESS

THE MACMILLAN COMPANY, AGENTS

LONDON: P. S. KING \& SON

1907 
c 


\section{CONTENTS}

I. The Economic Policy of Robert Walpole-Norris $A$. Brisco, Ph.D. . . . . . . . . . . . . I

3. The United States Steel Corporation-Abraham Berglund, Ph.D. . . . . . . . . . . . 223

3. The Taxation of Corporations in Massachusetts-Harry G. Friedman, A.B. . . . . . . . . . . . . . $40 \mathrm{I}$ 


$$
\text { ' }
$$




\section{1 \\ THE ECONOMIC POLICY OF ROBERT WALPOLE}



STUDIES IN HISTORY, ECONOMICS AND PUBLIC LAW EDITED BY THE FACULTY OF POLITICAL SCIENCE OF COLUMBIA UNIVERSITY

Volume XXVII]

[Number 1

\title{
THE ECONOMIC POLICY OF ROBERT WALPOLE
}

\author{
BY \\ NORRIS A. BRISCO, Ph.D.
}

Sometime Schiff Fellow in Columbia University

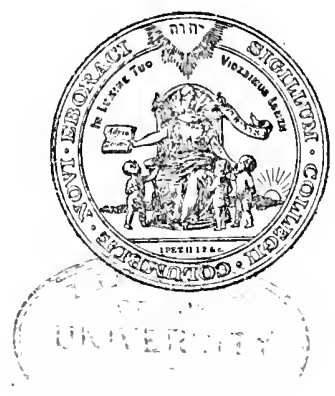

Nrw Dork

THE COLUMBIA UNIVERSITY PRESS

THE MACMILLAN COMPANY, AGENTS

LONDON : P. S. KING \& SON

1907 
Copyright, I907

BY

N. A. BRISCO 
To bis ancle, GEORGE I. HAM,

A MAN WHO BY HIS GENIUS

HAS MADE A SUCCESS IN THE FINANCIAL WORLD, THE AUTHOR DEDICATES

THIS BOOK 


\section{PREFACE}

THE following pages constitute a study that was commenced at the suggestion of Professor Seligman. There has hitherto been no systematic treatment of the economic policy of the administration of Robert Walpole and it was felt that here was a field for study. Care has been taken to arrange the economic facts in order, so that this monograph may be of some service as an economic history of the period. The writer trusts that he will be able to continue his studies and to treat other periods of the eighteenth century in a similar manner.

Among the different sources mentioned in the book, attention must be directed to the numerous pamphlets of the period. Much information has been obtained from the perusal of scores of these pamphlets. The writer feels very grateful to Professor Seligman for extending to him the privilege of his library which, with the exception of the British Museum, and perhaps the Foxwell library, now in London, contains the best collection in existence of the pamphlet literature of the period.

It must be remembered that no pretense is made to any great originality of thought. The writer has indeed attempted to present the different economic theories arising from the discussion over the excise; but in this he does not claim any especial credit. If he has succeeded in throwing some new light on the economic policy of Robert Walpole, and in arranging in order 
the economic facts of the period so that they may be more accessible to students, he will feel satisfied. Whether the work which is the result of three years' study possesses any merit, the author leaves to the reader to decide.

Thanks more than the writer can express are due to Professor Seligman who has evinced from the beginning a great interest in the book and spared no pains in carefully reading the manuscript and offering many valuable suggestions. To Professor Seager, the author is indebted for assistance in the reading of the manuscript and the offering of many helpful criticisms. Grateful acknowledgment is expressed to Professor Clarke for his careful reading of the proof and his many valuable suggestions. Sincere gratitude is also expressed to Professors Short and Ferguson of Queen's University under whom the author received his college training in economics and English history.

N. A. B.

Columbia University, New York, March, 1907. 


\title{
CONTENTS
}

\author{
CHAPTER I
}

Robert Walpole, The MaN

England's economic policy after the Revolution $\ldots \ldots \ldots \ldots \ldots \ldots \ldots \ldots$ 19

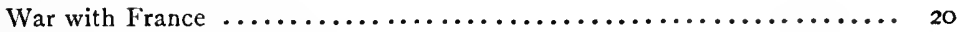

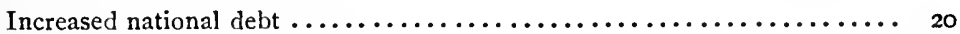

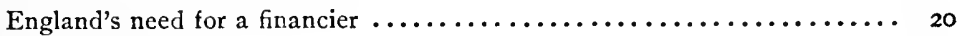

Robert Walpole............................... $2 \mathrm{r}$

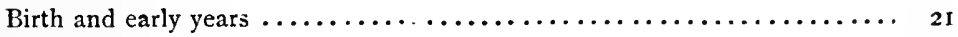

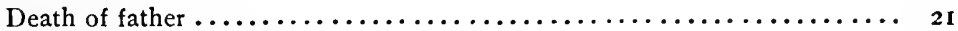

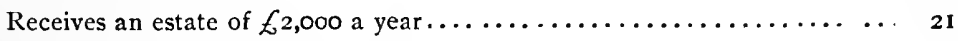

Enters Parliament.............................. 21

Student of financial questions $\ldots \ldots \ldots \ldots \ldots \ldots \ldots \ldots \ldots \ldots \ldots \ldots \ldots \ldots \ldots \ldots \ldots$

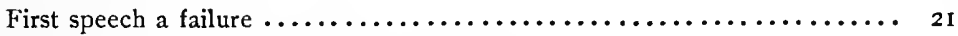

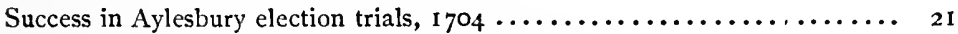

Member of the Council of the Lord High Admiral .............. 2 I

Reform of the department.......................... 22

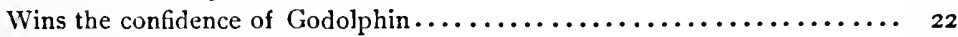

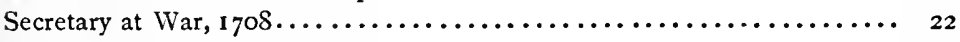

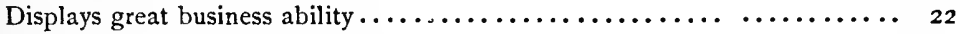

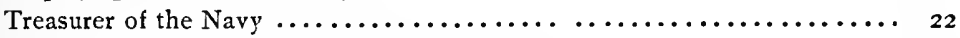

Reputation as a master of figures and accounts $\ldots \ldots \ldots \ldots \ldots \ldots \ldots \ldots .22$

Has charge of the impeachment of Dr. Sacheverell $\ldots \ldots \ldots \ldots \ldots \ldots \ldots \ldots 22$

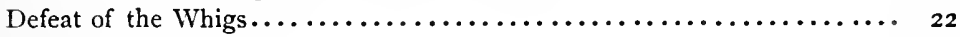

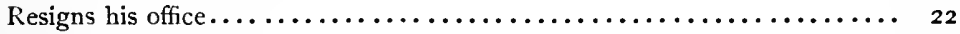

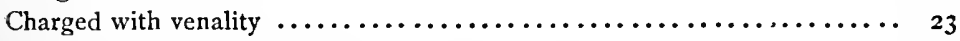

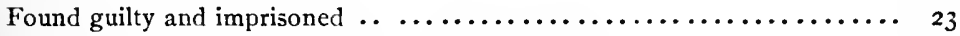

On release took prominent part in the opposition $\ldots \ldots \ldots \ldots \ldots \ldots \ldots \ldots$

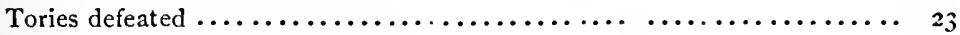

Appointed First Lord of the Treasury $\ldots \ldots \ldots \ldots \ldots \ldots \ldots \ldots \ldots \ldots \ldots \ldots$

Introduces resolutions regarding national debt................ 23

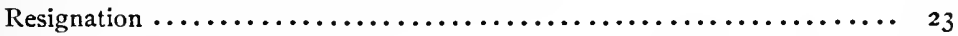

Bursting of South Sea Bubble........................ 24

Appointed First Lord of the Treasury $\ldots \ldots \ldots \ldots \ldots \ldots \ldots \ldots \ldots \ldots \ldots$ 


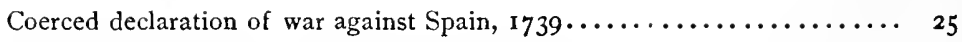

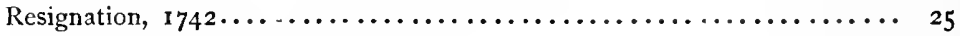

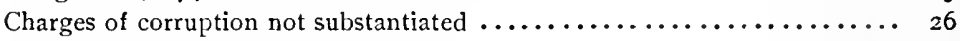

Sound advice often sought by the King.................. 26

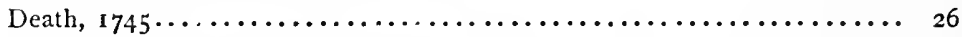

Period of his administration of greatest interest to student of politics..... 27

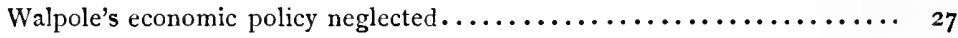

Necessity for such a study $\ldots \ldots \ldots \ldots \ldots \ldots \ldots \ldots \ldots \ldots \ldots \ldots \ldots \ldots \ldots \ldots$

\section{CHAPTER II}

\section{Fiscal Policy}

Importance of the study of the fiscal policy of England $\ldots \ldots \ldots \ldots \ldots \ldots \ldots$

Changes in methods of borrowing introduced at the Revolution ........ 30

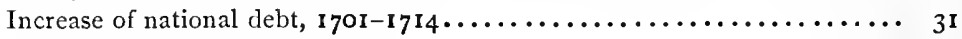

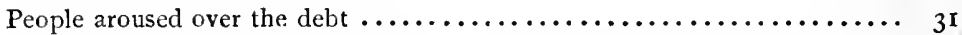

Walpole, Chancellor of the Exchequer and First Lord of the Treasury ..... 3 I

The King asks Parliament to devise scheme to pay national debts ...... 32

Account of public debts ordered by the House................ 34

Resolutions regarding the national debt $\ldots \ldots \ldots \ldots \ldots \ldots \ldots \ldots \ldots \ldots \ldots$

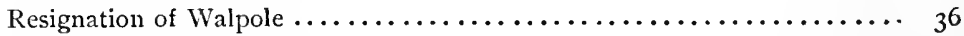

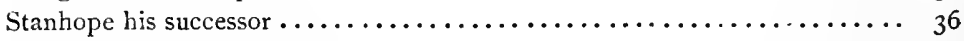

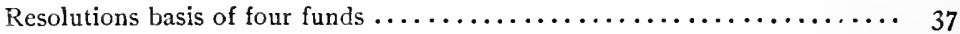

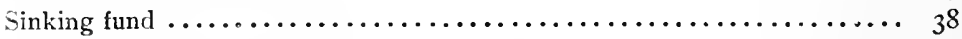

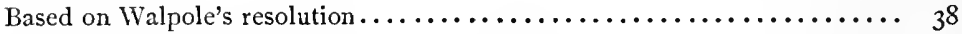

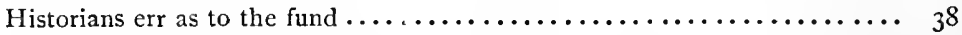

First sinking fund in England but not the first in Europe.......... 39

Surplus of fund and how appropriated $\ldots \ldots \ldots \ldots \ldots \ldots \ldots \ldots \ldots \ldots \ldots \ldots, 40$

Reduction of the national debt by the fund $\ldots \ldots \ldots \ldots \ldots \ldots \ldots \ldots \ldots \ldots$. 4 o

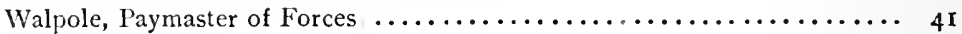

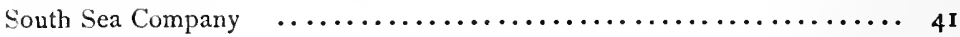

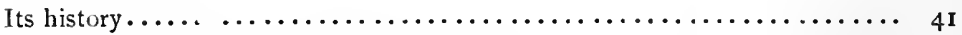

Struggle for conversion of national debts in $1720 \ldots \ldots \ldots \ldots \ldots \ldots \ldots \ldots 4$

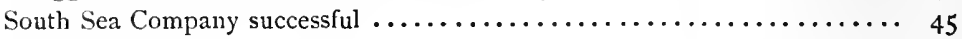

Speculative fever............................. 46

Attempts to inflate stock of the company $\ldots \ldots \ldots \ldots \ldots \ldots \ldots \ldots \ldots \ldots \ldots$

Bursting of South Sea Bubble...................... 46

Effect on England............................. 47

Walpole called upon to restore credit $\ldots \ldots \ldots \ldots \ldots \ldots \ldots \ldots \ldots \ldots \ldots .47$

Committee of Investigation appointed $\ldots \ldots \ldots \ldots \ldots \ldots \ldots \ldots \ldots \ldots \ldots \ldots$

Bank Contract. ............................... $5^{\mathbf{I}}$

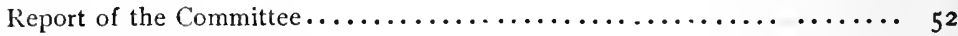

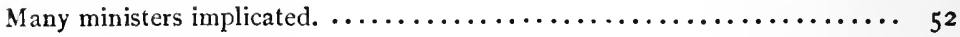


Powers of the South Sea Company checked $\ldots \ldots \ldots \ldots \ldots \ldots \ldots \ldots \ldots \ldots$

Fxchequer Bills................................ 59

- Changes introduced by Walpole.$\ldots \ldots \ldots \ldots \ldots \ldots \ldots \ldots \ldots \ldots \ldots \ldots$. 60

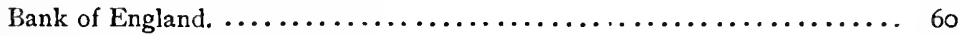

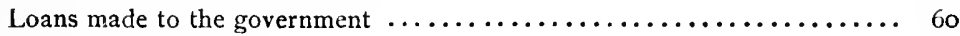

Stock of the Bank............................. 6 r

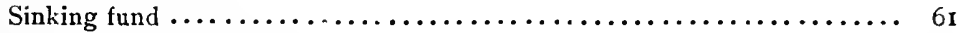

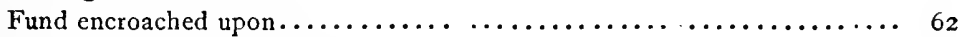

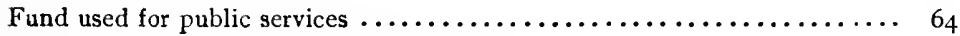

Arguments by opposition against perversion $\ldots \ldots \ldots \ldots \ldots \ldots \ldots \ldots \ldots \ldots 6_{5}$

Further appropriations from the fund $\ldots \ldots \ldots \ldots \ldots \ldots \ldots \ldots \ldots \ldots \ldots$

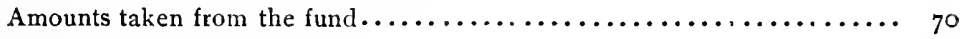

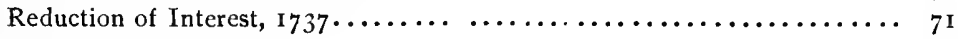

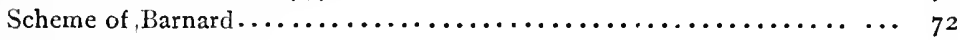

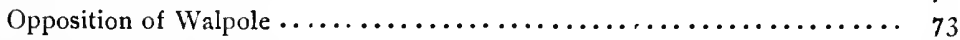

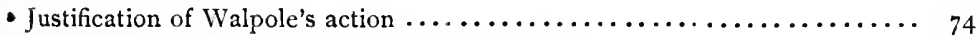

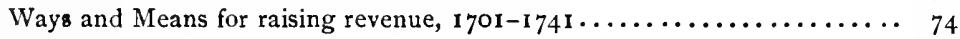

Conclusion $\ldots \ldots \ldots \ldots \ldots \ldots \ldots \ldots \ldots \ldots \ldots \ldots \ldots \ldots \ldots \ldots \ldots \ldots 8_{3}$

CHAPTER III

\section{REFORM IN TAXATION}

The problem of taxation $\ldots \ldots \ldots \ldots \ldots \ldots \ldots \ldots \ldots \ldots \ldots \ldots \ldots \ldots \ldots$

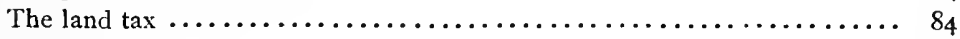

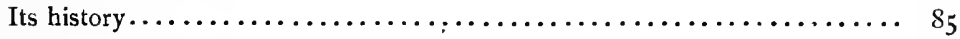

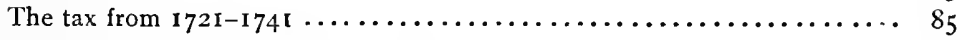

Rise of merchant classes $\ldots \ldots \ldots \ldots \ldots \ldots \ldots \ldots \ldots \ldots \ldots \ldots \ldots \ldots \ldots$

Political reasons for lowering the tax $\ldots \ldots \ldots \ldots \ldots \ldots \ldots \ldots \ldots \ldots \ldots 7$

- Walpole's theory of taxation $\ldots \ldots \ldots \ldots \ldots \ldots \ldots \ldots \ldots \ldots \ldots \ldots \ldots \ldots \ldots . \ldots 8$

Economic reasons for lowering the tax $\ldots \ldots \ldots \ldots \ldots \ldots \ldots \ldots \ldots \ldots \ldots$

Incidence of the $\operatorname{tax} \ldots \ldots \ldots \ldots \ldots \ldots \ldots \ldots \ldots \ldots \ldots \ldots \ldots \ldots \ldots \ldots$

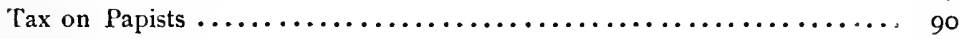

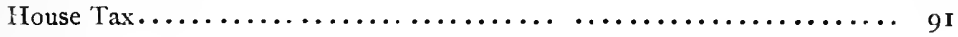

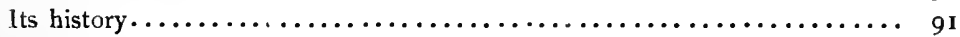

Excise.................................... 92

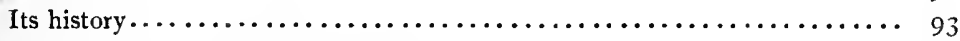

. Walpole's aim to check smuggling ..................... 94

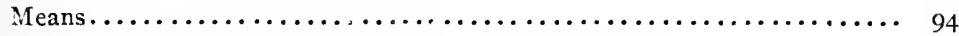

Change in duties on tea, coffee, cocoa-nuts and chocolate $\ldots \ldots \ldots \ldots \ldots .95$

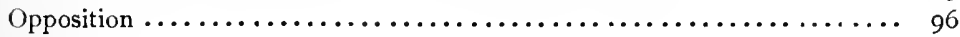

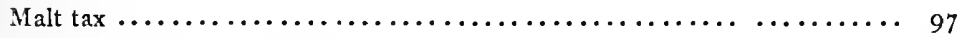

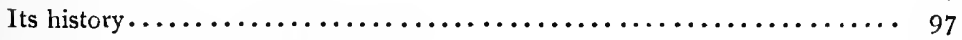

- Changes introduced by Walpole..$\ldots \ldots \ldots \ldots \ldots \ldots \ldots \ldots \ldots \ldots \ldots$. 97 
Excise on Compound spirits............................ 98

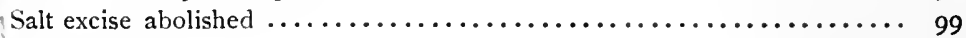

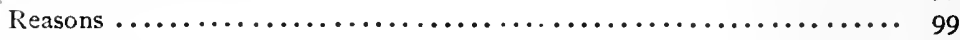

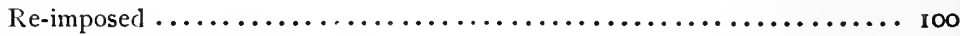

- Walpole's argument for the tax............................ 101

Opposition's arguments against.$\ldots \ldots \ldots \ldots \ldots \ldots \ldots \ldots \ldots \ldots \ldots$ roz

Theories of taxation brought forth in the controversy $\ldots \ldots \ldots \ldots \ldots \ldots$ I03

Theories brought forth as to incidence of excise.................. 104

Means used by opposition to arouse the people $\ldots \ldots \ldots \ldots \ldots \ldots \ldots \ldots$ ro5

First hint of the excise scheme $\ldots \ldots \ldots \ldots \ldots \ldots \ldots \ldots \ldots \ldots \ldots \ldots$ ro6

Anxiety of House over its introduction $\ldots \ldots \ldots \ldots \ldots \ldots \ldots \ldots \ldots \ldots$. 107

Walpole's speech introducing his scheme $\ldots \ldots \ldots \ldots \ldots \ldots \ldots \ldots \ldots$ ro 8

Excise scheme ................................... rog

Objections to scheme anticipated and answered by Walpole $\ldots \ldots \ldots \ldots$ I Io

Arguments by opposition against the scheme $\ldots \ldots \ldots \ldots \ldots \ldots \ldots \ldots$ I 2

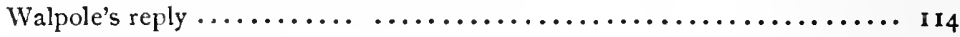

Antagonism to scheme............................... 115

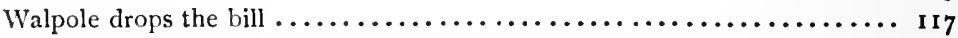

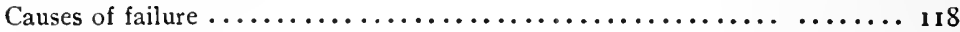

Warehouse system............................... I19

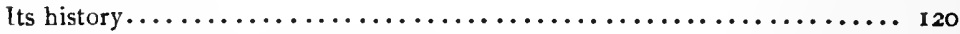

Walpole changes to tax on luxuries $\ldots \ldots \ldots \ldots \ldots \ldots \ldots \ldots \ldots \ldots \ldots$ I 20

- Controversy over excise scheme a political one................. I 22

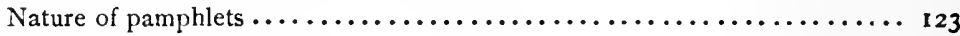

Other slight changes in excises and inland duties $\ldots \ldots \ldots \ldots \ldots \ldots \ldots \ldots$ I 24

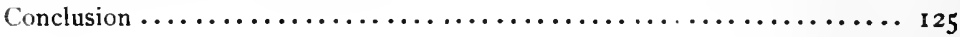

\section{CHAPTER IV}

\section{REFORMS IN THE TARIFF}

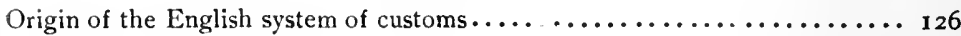

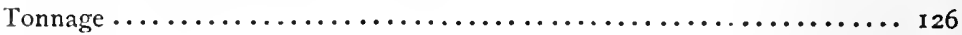

Poundage...................................... 26

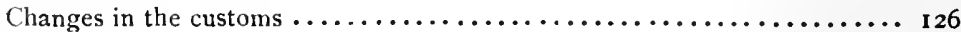

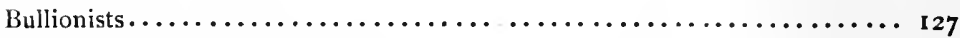

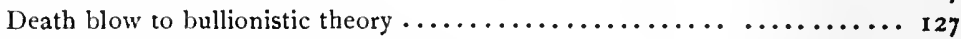

Scarcity of silver ... ............................. $\mathbf{1 2}_{28}$

Acts proposed for prohibition of precious metals $\ldots \ldots \ldots \ldots \ldots \ldots \ldots \ldots$ 1 28

| Origin of favorable balauce-of-trade theory $\ldots \ldots \ldots \ldots \ldots \ldots \ldots \ldots, 128$

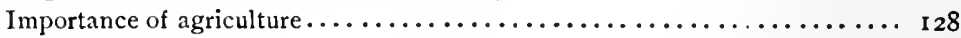

Views of North ................................. I 29

Abolition of export duties on woollen goods.................. I 29

- Industrial stage of mercantilism $\ldots \ldots \ldots \ldots \ldots \ldots \ldots \ldots \ldots \ldots \ldots \ldots$. 129 
King's speech in favor of aiding manufactures $\ldots \ldots \ldots \ldots \ldots \ldots \ldots \ldots \ldots$

Shipping first interest to statesmen.$\ldots \ldots \ldots \ldots \ldots \ldots \ldots \ldots \ldots \ldots \ldots$ I 3 I

Then agriculture $\ldots \ldots \ldots \ldots \ldots \ldots \ldots \ldots \ldots \ldots \ldots \ldots \ldots \ldots \ldots \ldots \ldots \ldots \ldots \ldots$

Then industry $\ldots \ldots \ldots \ldots \ldots \ldots \ldots \ldots \ldots \ldots \ldots \ldots \ldots \ldots \ldots \ldots \ldots \ldots \ldots \ldots$

Repeal of duties on exports......................... I $\mathbf{3}^{\mathbf{I}}$

Attention centers around industry $\ldots \ldots \ldots \ldots \ldots \ldots \ldots \ldots \ldots \ldots \ldots \ldots \ldots \ldots$

Repeal of duties on the importation of certain dyes............. 13 I

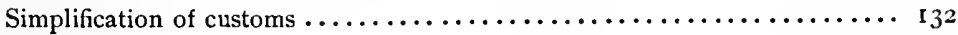

Beaver skins.................................. ${ }^{2}$

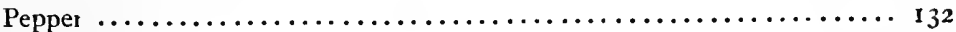

Mace................................ I $3^{2}$

Cloves...................................... $3_{32}$

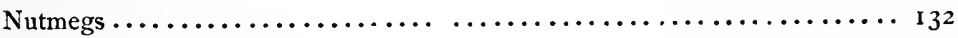

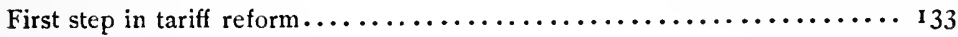

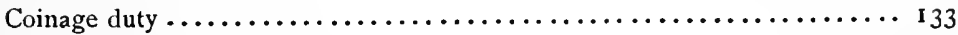

Change in duties on books $\ldots \ldots \ldots \ldots \ldots \ldots \ldots \ldots \ldots \ldots \ldots \ldots \ldots \ldots$

Change in the management of customs of England and Scotland $\ldots \ldots \ldots \ldots$

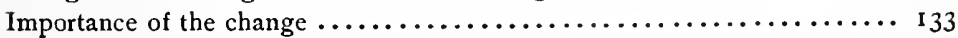

Repeal of duties on salt used in herring industry $\ldots \ldots \ldots \ldots \ldots \ldots \ldots \ldots$ I 34

Imposition of new duties on herrings................... I 34

Abolition of duties on whale products $\ldots \ldots \ldots \ldots \ldots \ldots \ldots \ldots \ldots \ldots \ldots \ldots$

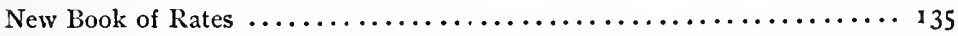

Repeal of additional duty of twenty per cent. on drugs imported ...... I 36

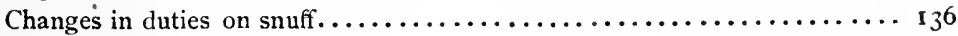

Free importation of cochineal ........................ I 36

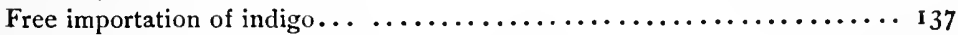

Changes in duties on wine-lees...................... 137

Duties on diamonds and precious stone abolished $\ldots \ldots \ldots \ldots \ldots \ldots \ldots \ldots$ I 37

Effect of the failure of excise scheme on tariff reform $\ldots \ldots \ldots \ldots \ldots \ldots \ldots$ I 38

Change in import duties on French oysters.................. ${ }_{3} 8$

Aim of mercantilistic period $\ldots \ldots \ldots \ldots \ldots \ldots \ldots \ldots \ldots \ldots \ldots \ldots \ldots$

Origin of smuggling $\ldots \ldots \ldots \ldots \ldots \ldots \ldots \ldots \ldots \ldots \ldots \ldots \ldots \ldots \ldots \ldots \ldots$

Its history $\ldots \ldots \ldots \ldots \ldots \ldots \ldots \ldots \ldots \ldots \ldots \ldots \ldots \ldots \ldots \ldots \ldots \ldots \ldots \ldots \ldots \ldots$

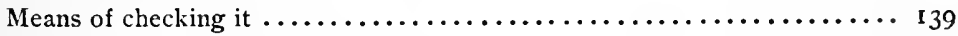

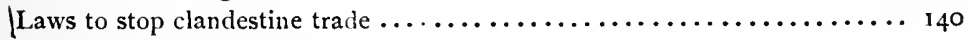

Increase of powers of excise officers....................... I 1

Strict regulations to govern sale of coffee and tea and the making of choco-

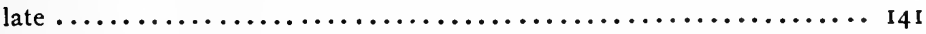

Greater rewards given for confiscated goods................ I 4 I

Laws against smuggling made more severe $\ldots \ldots \ldots \ldots \ldots \ldots \ldots \ldots \ldots \ldots$

Powers of officers extended $\ldots \ldots \ldots \ldots \ldots \ldots \ldots \ldots \ldots \ldots \ldots \ldots \ldots \ldots \ldots \ldots$

Abuse of powers of excise officers $\ldots \ldots \ldots \ldots \ldots \ldots \ldots \ldots \ldots \ldots \ldots \ldots$

Effect of the abuse $\ldots \ldots \ldots \ldots \ldots \ldots \ldots \ldots \ldots \ldots \ldots \ldots \ldots \ldots \ldots \ldots \ldots$

Conclusion.$\ldots \ldots \ldots \ldots \ldots \ldots \ldots \ldots \ldots \ldots \ldots \ldots \ldots \ldots \ldots \ldots \ldots \ldots \ldots \ldots \ldots$ 


\section{CHAPTER V}

\section{Bounties and Colonial Policy}

Commodities for export in seventeenth century $\ldots \ldots \ldots \ldots \ldots \ldots \ldots \ldots 145$

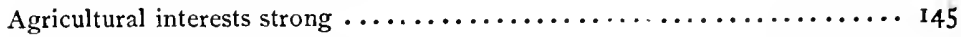

Bounty on corn $\ldots \ldots \ldots \ldots \ldots \ldots \ldots \ldots \ldots \ldots \ldots \ldots \ldots \ldots \ldots \ldots \ldots \ldots$

Great development of agriculture $\ldots \ldots \ldots \ldots \ldots \ldots \ldots \ldots \ldots \ldots \ldots \ldots \ldots$

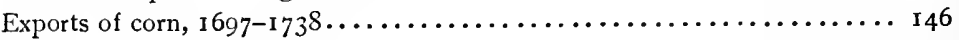

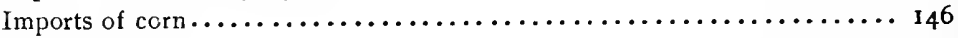

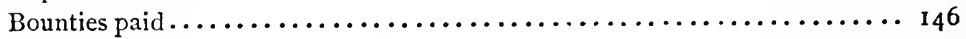

Checks to fraud in measuring corn $\ldots \ldots \ldots \ldots \ldots \ldots \ldots \ldots \ldots \ldots \ldots \ldots$ I47

Allowances granted on the exportation of English-made silk goods ....... I4 $\delta$

Bounties granted on British-made sails exported ................ 149

Bounty on exportation of British-made gunpowder $\ldots \ldots \ldots \ldots \ldots \ldots \ldots$ I 50

Bounty on ships engaged in whale fishery $\ldots \ldots \ldots \ldots \ldots \ldots \ldots \ldots \ldots \ldots$

Bounty granted on British refined sugar $\ldots \ldots \ldots \ldots \ldots \ldots \ldots \ldots \ldots \ldots \ldots$ I $_{5} \mathbf{I}$

Bounty granted on exportation of spirits drawn from corn $\ldots \ldots \ldots \ldots \ldots \ldots \mathbf{I}_{5} \mathbf{I}$

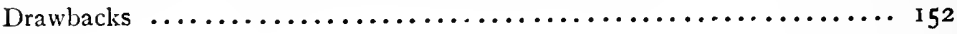

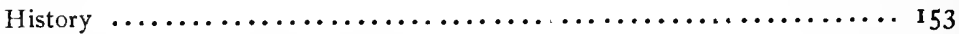

War against fraud and smuggling $\ldots \ldots \ldots \ldots \ldots \ldots \ldots \ldots \ldots \ldots \ldots \ldots \ldots$

Regulation of trade with Isle of Man $\ldots \ldots \ldots \ldots \ldots \ldots \ldots \ldots \ldots \ldots \ldots \ldots$

Repeal of drawbacks on re-exportation of foreign sails $\ldots \ldots \ldots \ldots \ldots \ldots$ I 54

Repeal of drawback on re-exportation of foreign paper $\ldots \ldots \ldots \ldots \ldots \ldots$ I 55

Repeal of drawback on re-exportation of foreign oysters $\ldots \ldots \ldots \ldots \ldots \ldots$ I 55

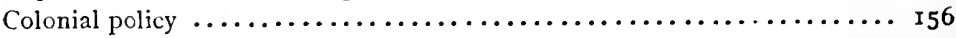

Encourage production of raw materials $\ldots \ldots \ldots \ldots \ldots \ldots \ldots \ldots \ldots \ldots \ldots \ldots \ldots \ldots \ldots$

Bounty on hemp and timber continued $\ldots \ldots \ldots \ldots \ldots \ldots \ldots \ldots \ldots \ldots \ldots$

Copper an enumerated commodity $\ldots \ldots \ldots \ldots \ldots \ldots \ldots \ldots \ldots \ldots \ldots \ldots \ldots \ldots$

Regulations governing cutting of white pine trees $\ldots \ldots \ldots \ldots \ldots \ldots \ldots \ldots 159$

Rice allowed to be carried directly from Carolina to Europe, south of Cape

Finnesterre .................................. 159

Georgia founded............................... 160

Privilege of Carolina extended to Georgia................... 160

Regulation of hat industry $\ldots \ldots \ldots \ldots \ldots \ldots \ldots \ldots \ldots \ldots \ldots \ldots \ldots \ldots \ldots$

Reduction of duty on colonial grown coffee $\ldots \ldots \ldots \ldots \ldots \ldots \ldots \ldots \ldots \ldots \mathbf{1 6}$

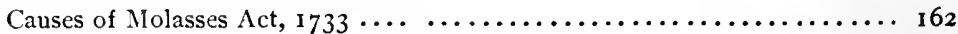

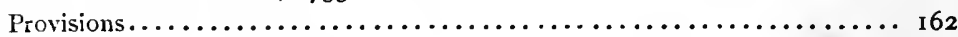

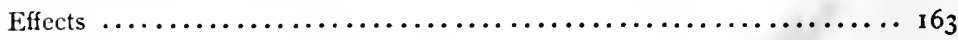

Privileges granted for shipping of sugar $\ldots \ldots \ldots \ldots \ldots \ldots \ldots \ldots \ldots \ldots \ldots \ldots$

Conclusion................................... $6_{5}$ 


\section{Industrial Policy}

Revolution a new epoch in England's economic policy $\ldots \ldots \ldots \ldots \ldots \ldots \ldots$

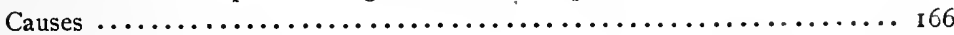

Imitation of Colbert $\ldots \ldots \ldots \ldots \ldots \ldots \ldots \ldots \ldots \ldots \ldots \ldots \ldots \ldots \ldots \ldots$

Revocation of the Edict of Nantes $\ldots \ldots \ldots \ldots \ldots \ldots \ldots \ldots \ldots \ldots \ldots \ldots$ I 66

Importance $\ldots \ldots \ldots \ldots \ldots \ldots \ldots \ldots \ldots \ldots \ldots \ldots \ldots \ldots \ldots \ldots \ldots \ldots \ldots \ldots$

Policy to encourage industry $\ldots \ldots \ldots \ldots \ldots \ldots \ldots \ldots \ldots \ldots \ldots \ldots \ldots \ldots \ldots \ldots$

Aids to industry $\ldots \ldots \ldots \ldots \ldots \ldots \ldots \ldots \ldots \ldots \ldots \ldots \ldots \ldots \ldots \ldots \ldots \ldots$

Government surveillance over manufacturing ................ I69

Regulations governing making of brick and tile $\ldots \ldots \ldots \ldots \ldots \ldots \ldots \ldots \ldots 169$

Regulations governing making of cloths and linens $\ldots \ldots \ldots \ldots \ldots \ldots \ldots$ I 70

Encouragement to makers of sail-cloth $\ldots \ldots \ldots \ldots \ldots \ldots \ldots \ldots \ldots \ldots$ I $\eta_{\text {I }}$

Irish goods smuggled to Europe $\ldots \ldots \ldots \ldots \ldots \ldots \ldots \ldots \ldots \ldots \ldots \ldots \ldots \ldots \ldots$ I 7 I

Care taken to check this trade $\ldots \ldots \ldots \ldots \ldots \ldots \ldots \ldots \ldots \ldots \ldots \ldots \ldots \ldots \ldots$

Exportation of colonial made hats or felts prohibited $\ldots \ldots \ldots \ldots \ldots \ldots \ldots \mathbf{I}^{2}$

Manufacture of narrow woollen cloths regulated $\ldots \ldots \ldots \ldots \ldots \ldots \ldots \ldots \mathbf{I}^{2}$

Manufacture of silver and gold wares regulated $\ldots \ldots \ldots \ldots \ldots \ldots \ldots \ldots \ldots \ldots \ldots \ldots \ldots$

Labor problem $\ldots \ldots \ldots \ldots \ldots \ldots \ldots \ldots \ldots \ldots \ldots \ldots \ldots \ldots \ldots \ldots \ldots \ldots \ldots$

Assessment of wages fallen into disuse $\ldots \ldots \ldots \ldots \ldots \ldots \ldots \ldots \ldots \ldots \ldots$

Combinations...................................

Greatest strength in the woollen manufactures............... I 73

Attempt by royal mandate to check them $\ldots \ldots \ldots \ldots \ldots \ldots \ldots \ldots \ldots$ I 73

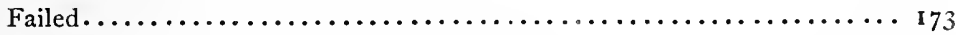

Petitions to Parliament against combinations.. .............. I 73

Act to prevent unlawful combinations of workmen $\ldots \ldots \ldots \ldots \ldots \ldots \ldots$ I 74

Provisions ..................................... 174

Petitions of weavers against master clothiers $\ldots \ldots \ldots \ldots \ldots \ldots \ldots \ldots \ldots$ I 75

No attention paid to petitions by the House $\ldots \ldots \ldots \ldots \ldots \ldots \ldots \ldots \ldots$ I 76

Combinations increase $\ldots \ldots \ldots \ldots \ldots \ldots \ldots \ldots \ldots \ldots \ldots \ldots \ldots \ldots \ldots \ldots \ldots$

Labor strike................................ 176

Success of the laborers $\ldots \ldots \ldots \ldots \ldots \ldots \ldots \ldots \ldots \ldots \ldots \ldots \ldots \ldots \ldots \ldots \ldots$

- Beginning of the social chasm between labor and capital.... ...... I 77

Public attention directed to manufactures................. 177

Growth of the woollen manufactures $\ldots \ldots \ldots \ldots \ldots \ldots \ldots \ldots \ldots \ldots \ldots \ldots$

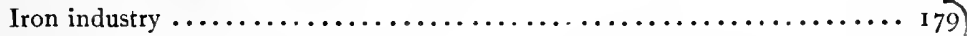

Silk manufactures............................ 8 o

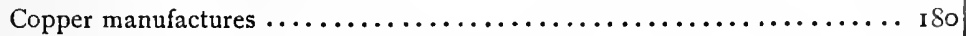

Brass manufactures.............................. 180

Linen industry $\ldots \ldots \ldots \ldots \ldots \ldots \ldots \ldots \ldots \ldots \ldots \ldots \ldots \ldots \ldots \ldots \ldots \ldots \ldots \ldots \ldots$

Growth of industrial and commercial towns $\ldots \ldots \ldots \ldots \ldots \ldots \ldots \ldots$ I $\mathrm{I}_{\mathrm{I}}$

Great increase in export of $\operatorname{corn} \ldots \ldots \ldots \ldots \ldots \ldots \ldots \ldots \ldots \ldots \ldots \ldots$ 


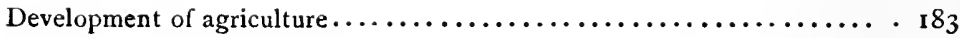

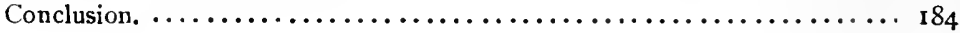

\section{CHAPTER VII}

\section{Foreign Trade}

- Importance of commerce to England..................... 186

Early commerce dependent upon the wills of Kings............... 186

Important work of Cromwell............................ 187

Downfall of the Dutch commercial suprcmacy $\ldots \ldots \ldots \ldots \ldots \ldots \ldots \ldots$ i 87

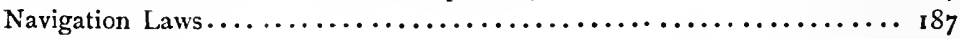

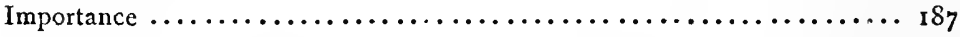

Prohibition of importation of many French commodities $\ldots \ldots \ldots \ldots \ldots \ldots$ I 87

Repeal of the act............................... 188

Revolution introduced new era in England's foreign trade policy ........ I 88

Cause of Methuen Treaty.$\ldots \ldots \ldots \ldots \ldots \ldots \ldots \ldots \ldots \ldots \ldots \ldots \ldots \ldots \ldots$

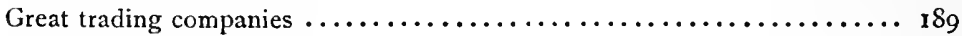

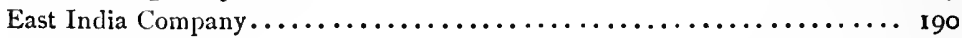

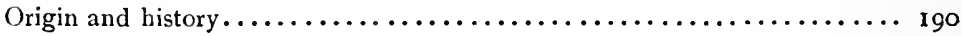

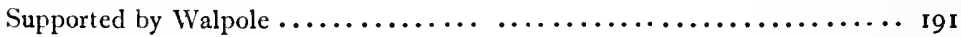

Ostend Company. ................................ rgr

Competes with East India Company $\ldots \ldots \ldots \ldots \ldots \ldots \ldots \ldots \ldots \ldots$ I 9 I

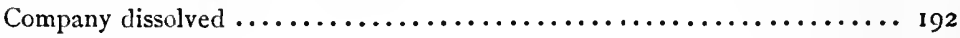

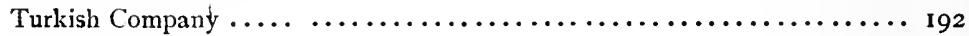

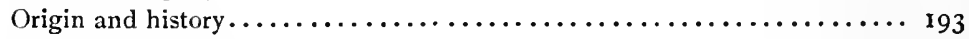

- Favored by Walpole................................... 193

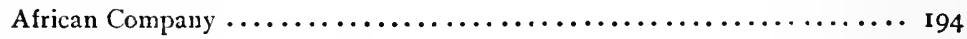

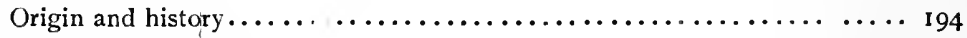

- Assisted by Walpole.................................... 194

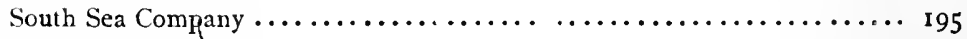

- Origin and history................................. 195

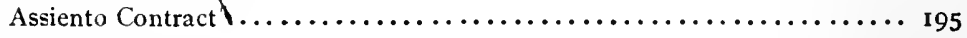

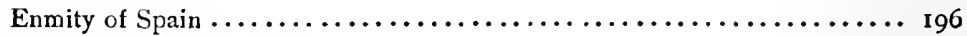

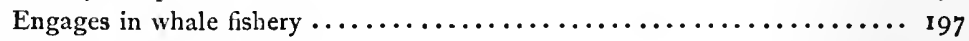

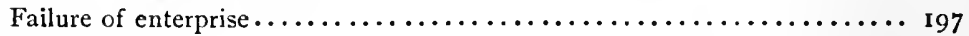

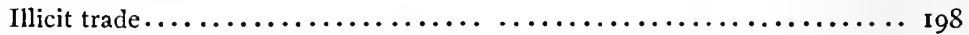

I'etitions of Jamaica merchants against seizures by Spanish ships........ I 98

Demand by House of Commons for redress . . . . . . . . . . . . . . . I99

Preliminary convention with King of Spain $\ldots \ldots \ldots \ldots \ldots \ldots \ldots \ldots \ldots$. 99

Terms ......................................... 2 2co

Harsh demands of Spanish king........................ 200

The people dissatisfied...................................200

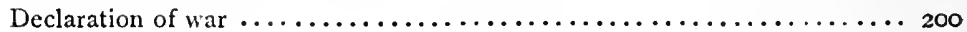




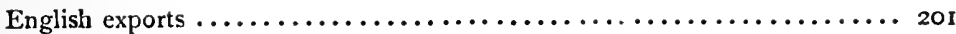

Loss caused by the war................................. 20 r

South Sea Company cause of trouble with Spain................ 201

South Sea Company a detriment to English trade. ................ 201

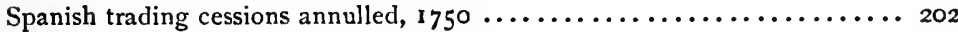

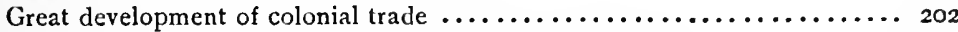

- Policy of Walpole in accorcance with the colonial system ............ 202

State of trade in Massachusetts.............................. $20_{3}$

New England States................................. 203

Virginia and Maryland................................... 204

Carolina ........................................... 204

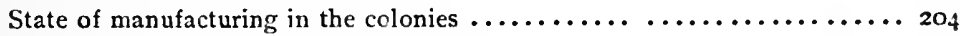

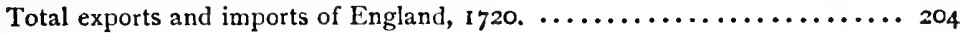

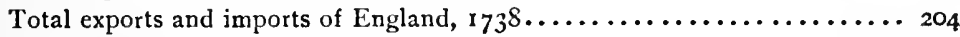

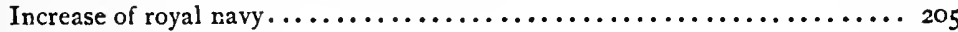

. Conclusion........................................... 206

\section{CHAPTER VIII}

\section{England's DebT to WaLPole}

- Political importance of Walpole's administration.................. 207

-Well defined economic policy ................................ 207

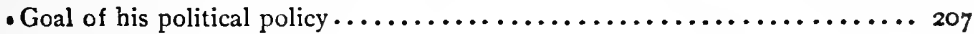

4 Fiscal policy ......................................... 208

Assistance given to the manufacturer....................... 208

Caution necessary in the repeal of import duties $\ldots \ldots \ldots \ldots \ldots \ldots \ldots \ldots . .209$

Firm belief of Walpole in the colonial system .................. 2ro

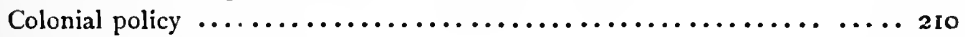

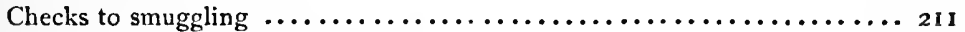

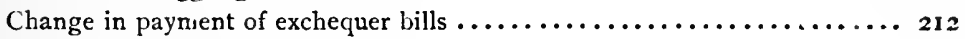

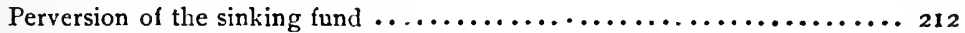

Revival of the salt tax and effects......................... $21_{3}$

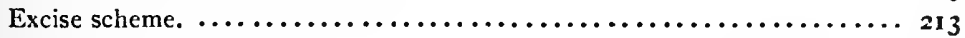

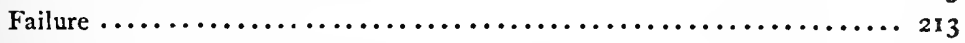

Extension of warehouse system $\ldots \ldots \ldots \ldots \ldots \ldots \ldots \ldots \ldots \ldots \ldots \ldots \ldots \ldots \ldots \ldots \ldots \ldots$

Opposition of Walpole to reduction of interest in $1737 \ldots \ldots \ldots \ldots \ldots \ldots 214$

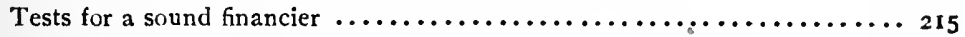

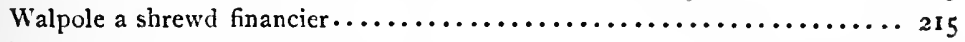

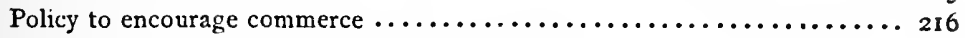

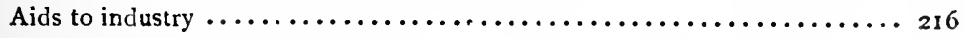

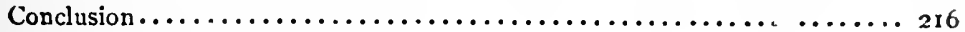




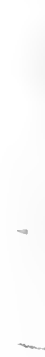




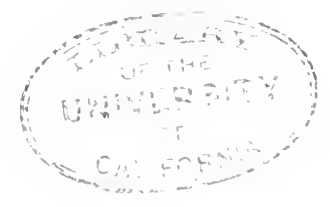

\section{CHAPTER I}

\section{Robert Walpole, the Man}

THE Revolution marked a new epoch in the constitutional history of England. It gave a powerful impulse to the great constitutional progress that was transferring the sovereignty from the King to the House of Commons. From the political point of view the accession of William III was, therefore, of the greatest importance to every Englishman. From the economic point of view, the Revolution denoted a cliange, which, if not as important as the political one, greatly influenced England's industrial welfare. To the economist, William's reign, marked the beginning of a new economic policy, the chief cause of which was the change from the bullionistic - to the mercantilistic conception of wealth. In future, trade was to be gauged by its influence on industry. . England had to depend on her exports for increase in wealth. The producer was the one who was to be specially favored and the government had in every way to assist him to produce as cheaply as possible in order that he might successfully compete in the foreign markets. Bounties and drawbacks gave assistance to agriculture and manufactures. The colonial system reserved the colonies to the home markets and commercial concessions secured by treaty gained new foreign markets for English goods. Restrictive legislation, as far as possible, confined the English market to the English producer. Such was the beginning of the development of English 
industry that, under a fostering care, increased with great rapidity and paved the way for the Industrial Revolution.

The accession of William put an end to the pernicious belief in the divine right of kings and securely established Protestantism in England. The King's strong Protestant views soon had England involved in a war with France. It was a struggle for the mastery of Europe as well as against Roman Catholicism. The great need of money, in order to keep large armies in the field, gave rise to the national debt. The war proved so expensive that at the close of William's reign the debt reached the enormous sum of $\mathfrak{f}_{1} 6,394,702$. $^{1}$ During the short reign of Queen Anne the war was still more costly, and at its conclusion in the Peace of Utrecht, the national debt

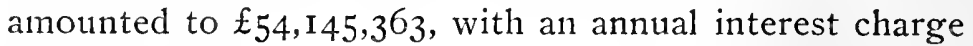
of $\mathfrak{x}_{3}, 35 \mathrm{I}, 35^{8}$. $^{2}$

The death of the Queen and the accession of the Hanoverian King followed in I7I4. The people were greatly agitated over the debt that, according to the claims of many, threatened to bankrupt the whole nation. The pessimists saw nothing but ruin staring them in the face, while the optimists believed that matters would so adjust themselves that the country would not be greatly embarassed. Some scheme for payment of the national debt had to be devised in order to satisfy the people and restore confidence in the government. England was sorely in need of a sound financier, a leader in peace, one in whom the people would have confidence, and who would assist in the development of English trade and industry. Such a man was found in the person of a country squire by the name of Robert Walpole.

${ }^{1}$ Sinclair, History of the Public Revenue, vol. i, p. 426.

'Ibid., vol. i, p. 439. 
Robert Walpole, son of Sir Robert Walpole, a typical country squire, was born at Houghton on the twentysixth of August, 1676. He was sent to a preparatory school at Massingham and then to Eton, where he was known as an effective debater and a forcible speaker. In 1696 he entered King's College, Cambridge; but two years later, on the death of his elder brother, he was called home to prepare to succeed his father to a country estate of about two thousand pounds a year. On the thirtieth of July, I7oo, Walpole married Miss Catherine Shuter, daughter of the Lord Mayor of London. On his father's death, November the twenty-eighth of the same year, he succeeded to the family estate, and in I 701 was returned to Parliament for his father's seat of Castle Rising. From the first he devoted his time to the mastery of questions of finance. He was enticed to enter the lists against his old college rival, St. John, but his maiden speech was a failure. Chagrined by this, he spent some time in studying the business of the House and making himself familiar with its modes and ways of practice. He served on several committees and, by taking an active part in the examining of witnesses, soon gained confidence in himself. In I702, on the accession of Queen Anne, he was returned for 'Lynn Regis. As a forcible speaker, he was brought prominently before the country by his speeches in the Aylesbury election trials of I704. He soon became known for his sound financial judgment, and it was only a short time before his advice was sought on all financial measures.

- Walpole gained the confidence of Lord Godolphin, and when the Whigs were returned to power he was appointed, in March, I705, as one of the council to the Lord High Admiral. No department had been more bitterly assailed, 
and Walpole consequently determined to revise and systematize its entire business. After a careful investigation he drew up a complete system of reform, and it was adopted. His suavity of temper and his political tact on more than one occasion saved his party from disruption. Following the elections of I705 his tactful measures united Godolphin and the Whigs. Godolphin consulted him on all occasions and intrusted him with the leadership of the House of Commons. His good work was rewarded by his appointment, in February, I708, to the post of Secretary at War. This was a very responsible cabinet office, the conduct of which demanded sound judgment and cool deliberation. He displayed such great business ability, tact and diplomacy that he justly deserves Hervey's praise, that no man ever was blessed with a clearer head, a truer or quicker judgment or a clearer insight into mankind. ${ }^{x}$ In I709, on the death of Sir Thomas Littleton, Treasurer of the Navy, he was appointed to that post, and for a time held both offices.

His reputation as a master of figures and accounts soon became so wide-spread that in all questions of finance the House relied more on his judgment than on that of Treasurer Godolphin. Mainwaring in speaking of Walpole remarked that his keen insight, his great mastery of finance, and his precision of accounts were marvelous. One of his bitterest enemies was forced to admit that in all transactions of money affairs the House relied more on his judgment than on that of any other member.

In I7 o he took charge of the impeachment of Dr. Sacheverell, and in the defeat of the Whigs that followed the trial, he resigned his office as Secretary at War. In

'Hervey, Memoirs of George the Second, vol. i, p. 23. 
the opposition, much to the embarrassment of St. John and his colleagues, Walpole used all his powers of debate to uphold the work of the late administration. St. John chose him as the member of the Whig ministry to be humiliated. The Tories wished to rid themselves of his powerful influence and Brownley, the Speaker, was forced to remark that it was impossible to carry any business through the House unless Walpole were removed. After a careful investigation of his official career, two slight charges of venality were brought against him. He clearly proved that he was not guilty of obtaining private gain, but he was found guilty, expelled from the House and sent to the Tower. His short imprisonment only served to increase his popularity, and on his release he found himself the recognized leader of the Whig party. He attacked the Tories with great vehemence, and aided Richard Steele in the publication of several political pamphlets. With the downfall of the Tory ministry he took the leading part in the impeachment of its leaders. His faithfulness was rewarded by his appointment, on the eleventh day of October, I7I5, as First Lord of the Treasury and Chancellor of the Exchequer. Thus the man in whom the people had the greatest confidence was called, at a critical time, to devise some scheme for paying off the national debt. Nor were his supporters disappointed. In due time the sinking fund was brought forth. The people were satisfied and confidence in the government was restored.

- After introducing his sinking fund, Walpole, owing to discord in the ministry, resigned in April, 1717. He took a prominent part in attacking the ministerial party. His greatest efforts were directed against the Peerage Bill. On the fourth of June, I720, he joined the Sunderland ministry with the minor post of Paymaster of the 
Forces. The following three months were spent in the country. The bursting of the South Sea Bubble, in September, threw the country into a panic and the people looked to Walpole as the only person able to restore confidence in public credit. He accepted the task, and soon brought harmony out of chaos. As the result of an investigation, several ministers were charged with fraud and forced to resign. In the changes that took place, we find on April the second, I72x, Robert Walpole restored to his old posts of First Lord of the Treasury and Chancellor of the Exchequer and Townsend again Secretary of State.

Walpole held his offices without a break for twentyone years, during all of which time his chief aim was to cause his country to increase in wealth and power. He believed that inclustry should be encouraged by every possible means, and that its growth should not be hindered by war. Spain was the country that Walpole had to treat with great care. The Spanish merchants felt sorely wronged over the trade concessions of the Peace of Utrecht, while the Spanish court felt very keenly the possession of Gibraltar by the English. The antagonism was so great that a slight provocation would have brought a declaration of war. Several times it required all Walpole's powers of stratagem and diplomacy to avert hostilities. / He knew that war would injure trade, divert capital from its industrial channels and take energy and men from trade and industry. He was for this reason always willing to make sacrifices to keep peace.

Chesterfield speaks of Walpole as the ablest manager of Parliament that ever lived, ${ }^{x}$ and Macaulay says that he was better acquainted than any man of his day with what

${ }^{1}$ Chestcrfield, Letters, vol. iii, p. 14I7. 
it concerned one most to know,-mankind, the English nation, the court, the House of Commons and the Treasury. ${ }^{\prime}$ According to Burke, Walpole was a man who governed by party attachments but gained very few from the opposition. ${ }^{2}$ Hume says that Walpole possessed many good qualities, but he incurred public hatred. ${ }^{3}$ Although a born leader of men, yet he did not wish to see any one possess power that would in any way interfere with his own. As a result, we find him keeping out of office many, clever and shrewd politicians. These formed a party, at first weak, yet made stronger by the addition of other discontented men, until by I732, we find a smouldering fire that at the first opportunity was ready to blaze forth into a great opposition.

- The opportunity came in the struggle over excise, and Walpole found himself confronted by an opposition stronger than he had ever anticipated. The defeat of the excise scheme, and the harsh treatment of all who * dared to oppose the minister, increased the opposition. The coerced declaration of war against Spain in 1739, marked his first great defeat. Walpole should have resigned; but his love for office made him cling tenaciously to the threads of power. On the eleventh of February I742, he was compelled to lay aside the sceptre that he had wielded so long. He was raised to the peerage with the title of Earl of Orford, and it was arranged that a pension of four thousand pounds a year should be bestowed upon him. This latter was not forthcoming until 1744 , when Walpole, driven by embarrassing circum-

${ }^{1}$ Macaulay, Critical, Historical and Miscellaneous Essays, vol. iii, p. 166 .

"Burke, Appeal from the New to the Old Whigs, p. 63.

'Hume, Essays, Moral, Political and Literary, vol. iv, p. 396. 
stances, asked Pelham to obtain the pension, which he rather reluctantly did.

The depression in trade caused by the war and bad harvests won a large portion of the country to the opposition. They attributed the hard times to the administration of Walpole and demanded that the great statesman be punished. An ardent Tory member of the House was commissioned to draw up articles of impeachment; but the charges framed did not meet with approval and they were dropped. On the ninth of March I742, Lord Limerick moved that a Committee of Inquiry be appointed to look into the administration of Walpole for the past twenty years. Later, the time was limited to the last ten years of his office-holding. On March the twenty-third, the motion passed with a small majority and a committee was appointed. With the greatest diligence they set to work, but could not find any serious charges against the statesman. This was the end of his political career. The King still relied on the sound judgment of his ex-minister, and frequently consulted him. He retired to his estate at Houghton. In the early spring of 1745 , word was received at London that the Young Pretender was about to land on English shores. At the same time, the Ministry was disunited by the quarrels between Carteret and Newcastle. At home and abroad England seemed to be in the greatest peril and needed a safe guiding hand. It was to Walpole that the King looked for counsel and he was hurriedly summoned from Houghton. Although the ex-minister was suffering great pain from a chronic disease, he hastened to London, but the four days' journey proved disastrous and shortly after arriving, he was compelled to take to his bed and died on the eighteenth of March. The period of Walpole's administration is of the great- 
est interest to the student of politics. After the Revolution the cabinet came to be recognized as consisting of men of one party. With the development of the cabinet a new office, a post of power and influence, was brought into existence. The development was slow and gradual. The first who made the office such as it is was Walpole. It was not till his time that the Prime Minister came to be regarded as the recognized leader of his party, the responsible adviser of the crown, and the head of the cabinet. He was the first statesman to recognize the advantages of a united cabinet, and the first premier. who resigned office in obedience to an adverse vote of the House of Commons. With him begins government. by Parliament.

Mr. Ewald has made a careful study of the political history of Walpole's period, and Mr. Basil Williams has paid as careful attention to the foreign policy of England, but Walpole's economic policy has been neglected and overlooked. The economic and the political circumstances constantly react on one another, and we can not understand real progress unless we pay attention to both. Many have marvelled at the great growth of political institutions during the long office-holding of Walpole, but they have forgotten that political greatness and political growth imply the existence of industrial prosperity and of sound industrial conditions. Economic affairs greatly modify the course of political events. One cannot form correct notions of the history of a country without being informed of its economic conditions and the economic policy pursued by its statesmen.

We must not allow ourselves to be biased by the many criticisms that historians have made of Walpole. To the average student, Walpole is known as the prince of bribers. May remarks that Walpole reduced bribery to 
a system. Historians have forgotten that he was a man of the times. They have overlooked the fact that it was the age of the "Spoils System," and that the political leaders of that period considered it legitimate then to grant favors in order to secure support and to retain office, however we may now condemn the practice. We could not expect Walpole to have lived in the first half of the eighteenth century and not to have used the means to remain in power that were then considered legitimate. With all the accusations that have been made, the investigating committee and his fiercest enemies could not, after his resignation, substantiate one single charge of corruption. We do not say that he was not corrupt in the sense of the present day, but we do affirm that he did not employ those practices which were in his day considered illegitimate. Edmund Burke gives us this side of Walpole's character: "He was not as the Jacobites and discontented Whigs of his time have represented him, and as ill-informed people still represent him, a prodigal and corrupt minister. They charged him, in their libels and seditious conversations, as having first reduced corruption to a system. Such was their cant. He governed by party attachments. The charge of systematic corruption is less applicable to him, perhaps, than to any minister who ever served the crown for so great length of time." x

The age of Walpole is to the political student a period of the greatest interest, to the diplomat a time of skillful foreign intrigues and stratagems, to historians an age in which there is little to chronicle. Green complains that year after year passed without a change. To the " economist, however, the age is one of great industrial

'Edmund Burke, Appeal from the New to the Old Whigs, p. 63. 
- growth and interesting economic changes. This can be shown by an investigation of the fiscal policy of Walpole's administration and of its tax reform, its tariff reform, its colonial system, its industrial policy and its foreign trade. 


\section{CHAPTER II}

\section{Fiscal Policy}

DURING the eighteenth century, historians are more interested in the political events of England than in her finances. They forget that the latter are closely connected with the former. They treat in great detail the work of political leaders, but leave to future students the working out of the fiscal policy of the period. The success of England in her continental wars is due as much to her great financiers as to her great political and military leaders. The first great financier of the century is Walpole, and he is known to the historian as a politician and "boodler" rather than as a financier. A correct knowledge of the history of this period is scarcely possible without a review of the financial policy. An inquiry into the fiscal system will shed light on his administration and bring into prominence his foresightedness and his ability as a financier.

With the establishment of the constitution in 1688 , the method of mortgaging the resources of the future by borrowing became a regular system and was followed as an easy method of providing for public services. The founding of the Bank of England, in 1694, made the debt national. Ever since then it had been increasing rapidly, every new war adding more to it than was paid off cluring the preceding term of peace. At the close of the year 1701 , the debt was $116,394,702$, with an annual 
interest charge of $\mathfrak{E}_{1}, 380,942 .{ }^{\mathrm{x}}$ By the close of the year I714, it had increased to $£_{54}, 145,363$, with an interest charge of $\mathfrak{f}_{3}, 351,35^{\circ} .^{\circ}$ The wars of William and Anne increased the national debt until it became an important duty of the financial administration to put a stop to its further growth and to provide for systematic payment of it. On the accession of George I, in I714, the debt was considered a monster that threatened to bankrupt the country. The people were greatly alarmed over its amount, and the question of assuring payment was a serious problem for the administration to solve. The belief that the government would not, in the near future, be able to meet its obligations, and the fear of a Jacobite rebellion, that might restore the Stuart dynasty, weakened the credit of the country. Many creditors believed they would lose their loans, and the situation became alarming. Something had to be done to pacify the people, to raise the credit of the country, and to restore confidence in the government. While the country was all astir, Robert Walpole was called to the post of First Lord of the Treasury and Chancellor of the Exchequer. ${ }^{3}$

During the latter part of the year I 7 I $_{5}$, the excitement caused by the revolt in Scotland in favor of the Pretender, and the feeling of unrest and disloyalty in many parts of England, caused the interest taken in the public debt to wane for a time. But as soon as the revolt was put down and peace restored, the national debt again attracted the attention of king and statesmen, and the people became greatly alarmed over its amount. Many were

'Sinclair, History of Public Revenue, vol. i, p. 426.

'Ibid., p. 439.

${ }^{3}$ Robert Walpole was appointed Chancellor of the Exchequer October the eleventh, 1715. Coxe, Memoirs of Sir Robert Walpole, vol. i, p. 122. 
the pamphiets that warned them of impending bankruptcy; many were the murmurs that prophesied ruin. In order to quiet the people some plan had to be devised to make provision for its payment. Numerous radical schemes were proposed. But in the sinking fund of Robert Walpole, the people found the assurance for which they were looking. It satisfied the nation and restored confidence in the government.

The King, in his opening address to Parliament, on February the twentieth, I7I7, warned the Houses of the insupportable burden of the national debts, and asked them to devise some method for reducing them. ${ }^{x}$ This received immediate attention from the House of Commons, and in the address to His Majesty, on February the twenty-second, they assured him that they would apply themselves with all possible diligence to the work of lessening, by degrees, the heavy burden-a course which would prove an effectual means of preserving to the public funds a certain security. ${ }^{2}$ The first action was that of Walpole in his motion on March the fifth, 1717, that whoever should lend any sum not exceeding $£ 600,000$, for the service of the public, should be repaid the same, with interest at four per cent., out of the first aid granted during that session of Parliament. ${ }^{3}$ This appears to have been a feeler, for the purpose of ascertaining the attitude of the moneyed classes, and especially of the creditors of the government. As was expected, it aroused considerable stir and comment. The creditors foresaw the lowering of the rate of interest on all the public funds. This, and the doubt concerning the security of the public debt, caused great uneasiness. The

'Hansard, Debates, vol. vii, p. 396.

${ }^{3}$ Ibid., p. 423 .

${ }^{3}$ Historical Register for 1717, p. 150. 
anxiety is shown in the speech of Mr. Lechmere, who said that several schemes and proposals for reducing the national debt had been printed and dispersed, and this gave the persons concerned in the public securities the greatest uneasiness. The general alarm which this aroused among moneyed men might very sensibly affect public credit, and be of very dangerous consequence. In order to prevent this, he thought it necessary to move that the House would come to a resolution to make good all parliamentary engagements. ${ }^{x}$ This drew forth a reply from Walpole, in the course of which he said that there had been several schemes published relating to the reduction of the national debts, but they were made by private persons. He assured the House that in a short time proposals would be laid before them which he hoped would give them satisfaction and meet with their approval. He accordingly moved that Mr. Lechmere's motion be amended to read that the House would make good the deficiencies of all parliamentary engagements."

While the House was in a Committee on the Supply Mr. Lechmere observed that the late vote for a loan at four per cent. was likely to prove ineffectual, as in three days only forty-five thousand pounds had been subscribed. Hence as the present exigency required a speedy supply, he moved that a day be appointed to consider further into the matter. ${ }^{3}$ Although the crushing of the revolt in favor of the Pretender, making the Hanoverian dynasty more secure, had also strengthened the public credit, it was yet considered somewhat doubtful. The public creditors were not as yet satisfied with the national security and had not full confidence in the government. They would not accept the current rate of four per cent., 
because they thought that the public debts embodied a certain amount of risk. Walpole in seconding the motion said that there was great necessity for it, as he had been informed that the reason the loan was not raised at four per cent. was because some stock jobbers had formed a combination to distress the government and ruin public credit. $^{x}$ Mr. Lechmere replied that the failure was not due to any combination against the good of the country, but was occasioned by some reflections on the moneyed men and a declaration that Parliament might exert its authority to extricate itself by reducing the national debts; such a declaration could not but alarm the persons concerned in the public securities. He had nothing to say as to those public debts that were redeemable by Parliament, but as to annuities, granted for a term of years, he was positive that they could not be meddled with without breaking in upon parliamentary engagements and violating the public faith. ${ }^{2}$ In answer, Walpole said that there never had been a design to use any compulsion with regard to the annuities. An alternative might be offered to the proprietors of the same, but it should be their choice, either to accept or to refuse. For such funds as were redeemable, nothing should be proposed that would not entirely accord with justice and public faith. ${ }^{3}$ The House of Commons ordered that the rate should be five per cent., and the whole loan was immediately subscribed.

An account of the public debts, stating the different funds, when granted, what terms remained, the amount of the original money, the sum paid off and the rate of interest, was ordered to be laid before the House on

${ }^{1}$ Hansard, op. cit., p. 426.

Ibid.

'Ibid., p. 427. 
March the twenty-third. ${ }^{x}$ When the account was presented, Robert Walpole, having in his hand the amount of the public debts, spoke at some length concerning the same, and then produced his scheme both for reducing the interest of redeemable funds, and for offering an alternative to the proprietors of annuities. His plan, on being approved, was embodied in a number of resolutions that were presented to the House by Mr. Farrer. The most important are as follows: that all public funds redeemable by law which did not exceed five per cent. be redeemed, or with consent of the proprietors be converted into an interest or annuity not exceeding that rate; that the King be enabled to borrow such sums of money as should be necessary to redeem the redeemable funds at any rate not exceeding five per cent.; that the annuities payable to the Bank of England and the South Sea Company be redeemed, or with the consent of the companies be changed into annuities not exceeding five per cent.; that the aggregate fund be redeemed, and that all savings which should arise upon any of the present funds by the proposed redemptions or reductions, be reserved, and applied, after all deficiencies that might happen upon any of the funds were made good, toward discharging and reducing the national debt. ${ }^{2}$ The resolutions, having been severally read a second time, were agreed to by the House, and bills were ordered to be brought in embodying them.

Before the bills were introduced, a change took place

${ }^{1}$ An account of the public debts is given in Tindal, History of England, vol. xxvii, pp. 34-57; or Journal of the House of Commons, vol. xviii, pp. 498-507.

${ }^{2}$ The resolutions are given in detail in Journal of the House of Commons, vol. xviii, p. 513; or Hansard, Debates, vol. vii, pp. 427-429. 
in the administration. Owing to a misunderstanding among the King's ministers, Walpole resigned. The first intimation of his withdrawing from the ministry is given in his speech introducing the Redemption Bill, when he said that he now presented that bill as a country gentleman, but hoped that it would not fare the worse for having two fathers, and that his successor would take care to bring it to perfection. ${ }^{2}$ His resignation occurred at a time when he was engaged upon a very important financial measure and was received with great surprise and much regret in the House. ${ }^{3}$ The King relied upon the sound judgment of his minister, and feared that his leaving office would result in financial distress and ruin. He did his utmost to have Walpole reconsider his resignation, but was unsuccessful. ${ }^{4}$

Lord Stanhope, Walpole's successor, was a man of military rather than financial or administrative ability. ${ }^{5}$ He paid more attention to military affairs and foreign

${ }^{1}$ April 10, I717.

${ }^{2}$ Hansard, op. cit., p. 442.

" "The resignation of Walpole caused a great sensation in the House of Commons, where regret for the want of his talents for finance seemed to prevail, and he was as much inveighed against for resigning, as he was afterwards reviled for remaining in power." Coxe, Memoirs of Sir Robert Walpole, vol. i, p. 188.

" The King showed great regret to part with him, and with many kind expressions endeavored to persuade him to keep his post; but though Mr. Walpole assured him that he would never swerve from his duty to so good and gracious a Master: yet at the same time he represented, how impossible it was for him to serve him in the present circumstance of affairs." Tindal, History of England, vol. xxvii, p. I3.

"The King himself so highly appreciated the services and talents of Walpole, that he dreaded his resignation." Coxe, op. cit., vol. i, p. I83.

"He refused to accept his resignation, expressed a high sense of his services in the kindest and strongest terms; declared that he had no thoughts of parting with so faithful a counsellor; entreated him not to retire and replaced the seal in his hand." Ibid., p. 184 .

"Lecky, History of England in the Eighteenth Century, vol. i, p. 320. 
matters than he did to the duties of his office. The country was still greatly agitated over the burden of the debt and the uncertainty of government security. As yet, we have only the resolutions reported by the committee to Parliament. Stanhope was very slow in acting upon these, and in order to hasten the matter, the King, in his opening address to Parliament, May the sixth, asked that the Houses take all proper methods for reducing the public debts, with a just regard to parliamentary credit. ${ }^{x}$ To this the House replied that they were truly sensible how much the ease and the prosperity of the subjects depended on the accomplishing that great and necessary work of reducing the public debts, and were resolved to carry it on in the most effectual manner with just regard to parliamentary credit. ${ }^{2}$ This was soon followed by proposals of the Bank of England and the South Sea Company for the reducing of national debts. ${ }^{3}$ Accordingly, on May the twentieth, Lord Stanhope laid these proposals before the House, and after undergoing some alterations, they became the foundation of three acts passed during the session for reducing the interest on a considerable part of the public debt and forming four great funds: namely, the General, the Bank, the Sinking and the South Sea Funds.

The reduction of interest enacted in the Bank ${ }^{4}$ and South Sea Acts ${ }^{5}$ was based on Walpole's plan, although in forming the Bank and South Sea Funds some alterations were made which Walpole thought were detrimental to the public, and to which he made some opposition. The General Fund Act ${ }^{6}$ was also built upon Walpole's foundation, and in the act is found a clause that gave

'Hansard, op. cit., p. 448. ' ${ }^{2}$ Ibid., p. 450. ' $I b i d .$, pp. 454-457.

${ }^{4} 3$ Geo. I, c. $8 . \quad{ }^{5} 3$ Geo. I, c. $9 . \quad 3$ Geo. I, c. 7. 
rise to the Sinking Fund. This reads as follows: "That all monies arising from time to time, as well for the surplus by virtue of the acts for redeeming the funds of the Bank and of the South Sea Company, as also for the surplus of the duties and revenues by this act appropriated to make good the General Fund, and the overplus monies of the General Fund, shall be appropriated and employed for the discharging of the principal and interest of such national debts as were incurred before the twentyfifth of December, I7I6, in such manner as shall be directed or appropriated by any future act of Parliament, to be discharged out of the same, and for none other use, interest, or purpose whatsoever." I These surpluses constituted the sinking fund, and the clause clearly defines the uses to which it was to be appropriated. The act was passed in 1717 , and not in 1716 , as many historians state. The sinking fund was based on Walpole's plan as found in the resolutions of March the twenty-third. ${ }^{3}$ Walpole hence proposed the scheme of reducing the national debt by a sinking fund and formulated the plan, but it became a law by an act passed during the administration of Lord Stanhope.

Many historians and writers of note have erred in their statements concerning the origin of the fund. Mr. Lecky says the sinking fund was first proposed by Lord Stanhope and was established by Walpole in I716.4 Dr. Hamilton declares that the author of the fund was the Earl of Stanhope although it was adopted under the adminis- tration of Robert Walpole. ${ }^{5}$ McCulloch claims that the fund was first proposed by Stanhope and adopted by

\footnotetext{
'Tindal, op. cit., p. $65 . \quad$ '3 Geo. I, c. $7 . \quad$ 'Vide, p. 35.

-Lecky, op. cit., vol. v, p. 47.

${ }^{3}$ Hamilton, National Debt, p. 135.
} 
Walpole in I716. ${ }^{1}$ These eminent writers have reversed the actual facts concerning the origin of the fund, which, as we have seen, was proposed by Walpole and carried into effect during the administration of Lord Stanhope. As the sinking fund played an important part in English financial history all through the eighteenth century, it seems surprising that so many erroneous statements have been made concerning its origin.

The question might arise as to whether this was the first sinking fund in history. Funds which provided for sinking particular debts had existed for some time in England, as in the case of those granted for cancelling and exchanging exchequer bills. These funds not only paid the interest on the bills but yielded a surplus which was computed to be sufficient to cancel annually part of the bills, and likewise in the case of short annuities the principal was to be sunk at the end of the term granted. These may indeed be looked upon as sinking funds attending these particular debts, but Tindal says that Walpole's fund was the first attempt made by Parliament to establish a general sinking fund. ${ }^{2}$ Palgrave also contends that the first plan for the discharge of the national debt was Walpole's sinking fund. ${ }^{3}$ If we go to the continent, according to Pensionary de Wit, the interest on the national debt of Holland was reduced in $\mathrm{I} 655$ from five to four per cent., and the amount saved was used for the purpose of discharging the national debt. ${ }^{4}$ This is claimed by Anderson to have been the first sinking fund in Europe. ${ }^{5}$ Thirty years later, according to Bishop Burnet in his

'McCulloch, Taxation, p. 476. 'Tindal, op. cit., p. 65.

'Palgrave, Dictionary of Political Economy, vol. iii, p. 405.

'Quoted by Anderson, Annals of Commerce, vol. ii, p. 575.

Ibid. 
"Letters and Travels," Pope Innocent XI reduced the interest on the Papal debt from four to three per cent. and with this saving, planned to pay off the debt of the ecclesiastical state. These are the only two instances we have of sinking funds until Walpole's time.

The surpluses paid into the fund at first amounted to $\mathfrak{E}_{324,455^{\mathrm{x}}}$ The average annual produce from $\mathrm{I} 7 \mathrm{I} 7$ to

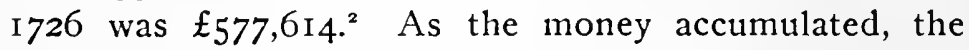
national debt was to be redeemed by act of Parliament. The first payment was made in $1719^{3}$ and by Christmas, $1727, \mathfrak{f 6}, 626,404$ of the debt incurred before the twentyfifth of December, 1716, was redeemed.4 The surplus was received and expended according to the act establishing the fund. The sinking fund was held to be inviolate, and money could not be taken therefrom to meet deficits elsewhere. During this period, however, it was necessary to borrow $\mathfrak{E}_{3}, 927,988^{5}$; and in consequence the net

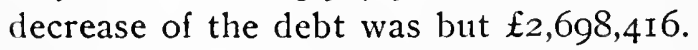

Did Walpole think of the sinking fund as a fund accumulating at compound interest? We must answer this in the negative. In all Walpole has written and said concerning the fund, he never referred to this conception of it. The first man to expound this theory was Nathaniel Gould in a pamphlet entitled "An Essay on the Public Debts of this Kingdom," ( 1726$).^{6}$ Gould had

'Sinclair, Public Revenue, vol. i, p. 485.

"Hamilton, op. cit., p. $138 . \quad{ }_{5}^{5}$ Geo. I, c. 3.

'Journals of the House of Commons, vol. xxi, pp. 122-123.

'Ibid., p. 123 .

${ }^{6}$ Published by McCulloch in Lord Overstone, Tracts on National Debt and the Sinking Fund, London, 1857.

Gould wrote another essay on the National Debt in answer to criticisms made of his first essay. This was entitled $A$ Defence of an Essay' on the Public Debts of the Kingdom. 
the utmost faith in his scheme of allowing funds to accumulate at compound interest. ${ }^{2}$ The theory was expounded at great length by Price, ${ }^{2}$ and was the foundation of Pitt's sinking fund. ${ }^{3}$

Walpole after his resignation in April, I7 17 , carried on a vigorous opposition. He sought every opportunity to embarrass the government. In the spring of 1720 , Sunderland got into difficulty and overtures were made to Walpole to join him. His love of office was so great that on the fourth of June he accepted the insignificant post of Paymaster of the Forces. New attempts were made to get him to form a coalition, but in this Sunderland failed and Walpole spent the following five months in the country. A speculative fever seized the land, and in September the bursting of the South Sea Bubble threw the country into a panic.

In order to understand the relation between the South Sea Company and the government, it will be necessary to go back to the origin of the company and give a short review of its history up to the bursting of the Bubble. Harley, even before his dismissal from office by Marlborough in 1708 , had commenced to intrigue with Mrs. Masham, a court favorite, to win the Queen's favor. The fruit of these intrigues was seen August the eighth, I7Io, in Godolphin's dismissal and Harley's appointment to the vacant post.

' An annual sum of $61,000,000$ paid into a sinking fund Gould claimed would at 4 per cent. compound interest, produce at the end of 105 years. the sum of 61,575 millions. Essay on Public Debts of this Kingdom. p. 33 .

${ }^{2}$ Richard Price, An Appeal to the Public on the Subject of the National Debt, 1774; Observations on Reversionary Payments, vol. i, pp. 185-228.

'For a criticism of Pitt's sinking fund see Hamilton, National Debt. pp. 195-207. 
Upon entering office, Harley found the national debt in a very entangled state and public credit at a very low ebb. Earl Godolphin left a debt upon the navy of five millions, ${ }^{x}$ and this had no parliamentary security. Navy tallies sold at a discount of forty per cent. while almost every kind of naval stores cost the government more than a double price. Harley's great aim was to restore peace, but before this could be done he felt it necessary to win over the moneyed classes, who were much opposed to the change in the ministry and his proposition of peace. This could be no better secured than by adopting some scheme to restore public credit.

It was found that the floating debt of the army and navy, with a few other deficiencies, amounted to nearly nine millions. An additional sum had to be raised for current expenses for the year I7II. Harley's proposal to Parliament was to form all these amounts, making a total of $£_{9,47} \mathrm{I}, 325$, into a fund ${ }^{2}$ and to secure the interest at the rate of six per cent. by making perpetual the duties on wines, vinegar, tobacco, East India goods, wrought silks and whale fins, and several other duties which were appropriated for certain years to come for other purposes, and in the meantime, to have the deficiencies guaranteed by the treasurer of the navy. ${ }^{3}$ The majority of the creditors were, at first, strongly opposed to the project. These were won over by the offer of a monopoly of the trade to the South Seas, and of special trade con-

' Rapin, History of England, vol. xxiv, p. 80.

'Anderson, op. cit., vol. iii, p. 258; Rapin, op. cit., vol. xxiv, p. 83 . The sum of $£ 9,471,325$ was only an estimate; two years later it was directed that an account of the actual stock of the South Sea Company be made out and transmitted to the Exchequer. This was found to be $69,177,967$.

"MacPherson, Ansals of Commerce, vol. iii, p. I9. 
cessions in the coming treaty of peace with Spain; by the revival of the stories of Drake and Raleigh who made this country a new Eldorado; by the encouragement of the belief that the power of Spain was not strong enough to enforce her strict trade regulations in the new world. Harley's proposal soon became very popular, and passed the House with a large majority. The allurements of the profits of the trade to the South Sea attracted great attention, and the company was called the South Sea Company. In effect, therefore, the creditors of the government became stockholders of the South Sea Company, and the government turned over to the company an annual sum equivalent to six per cent. interest on the stock, which was then transmitted to the stockholders in addition to any profits that might come from the commercial operations of the company.

In I 75 the stock of the company was increased to ten million pounds. ${ }^{2}$ Two years later the directors agreed to accept a reduction of one per cent. in interest. ${ }^{3}$ In I 7 I9, the government proposed to increase the company's stock by $£ 2,500,000, £ 1,721,250$ being the lottery annuities, ${ }^{4}$ established in 17 IO, which the company now agreed to take over, and the remainder, $\mathfrak{x}_{778,750}$, representing a sum which the company agreed to advance the govern-

${ }^{1}$ The company also received from the government an annual allowance of $£ 8000$ for management.

'I Geo. I, sess. 2, c. 21 . ${ }^{3} 3$ Geo. I, c. 9 .

'In I710, the government, in order to raise $\mathscr{E}_{1,500,000}$ to carry on the war, made use of the lottery. The tickets sold at $£$ io and the purchasers were entitled to annuities for 32 years. The holders of blanks received an annuity of $14 \mathrm{~s}$., while the holders of "benefit tickets," $i . e .$, the prizes, received annuities varying from $£ 5$ to $\measuredangle$ Iooo. $C f .8$ Anne, c. 4. This debt was known as the "lottery annuities of I710," and the obligation to pay the annuities was, as stated in the text, transferred to the company in I7 $x$. 
ment in money for public services. ${ }^{x}$ Many of the holders of the lottery annuities refused to accept the conditions provided for in the act, so that the total capital added to the company's stock was only $\mathfrak{f}, 746,844$. In July, I7 I9, the company opened a subscription for the sale of $£_{520}$,ooo of the new stock, which was sold at the price of II4.

This experiment proved so successful that the government resolved to try and do likewise with all the irredeemable annuities created at different times during the reigns of William and Anne. The ministry begged the officers of the company to make a proposition to Parliament for reducing all these annuities into a redeemable state, that is, for making it possible for the government to redeem the so-called irredeemable annuities by having the company give each annuitant a lump sum, which would be the present worth or capitalized value of the annuity. The ministry, however, knew that the company had made a profit in I 719 in the matter of the I7IO lottery annuities. For the annuitants had been given the privilege of selling their annuities at a capitalized sum to the company for cash or in return for the company's stock at market value. When the company paid cash it had the right to increase its capital stock by the amount so paid. When the company issued stock it had to pay to the annuitant an equivalent in market value of the South Sea stock, and still retained the right of issuing enough additional stock to bring the total up to the par value of the capitalized annuity. Owing to the fact that the South Sea stock sold at a premium in 1719 the company made a considerable profit by this exchange. The government accordingly now demanded from the company the payment of a premium for the privilege of 
having "the debts subscribed into their stock," $i$. $e$., the privilege of converting the holders of government annuities into stockholders of the South Sea Company. After some deliberation the company made an offer to

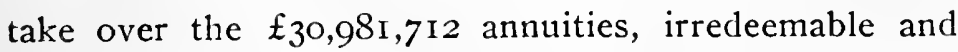
redeemable, either by purchase or by voluntary subscription at such price as should be agreed upon between the company and the annuitants, to accept five per cent. interest until midsummer, 1727 , then four per cent., and after that date to accept the redemption of the annuities by Parliament." For the irredeemable annuities the company offered twenty years' purchase for the 96 and 99 year annuities and fourteen years' purchase for the 32 year annuities. The company was to receive for management an additional sum bearing the same ratio to the new stock as the sum received at that time bore to the old stock. For this privilege the South Sea Company offered to pay three and a half million pounds. As soon as the proposition became known, the Bank of England raised the bid to over five and a half millions. ${ }^{2}$ The government accordingly changed its plan and offered the privilege to the highest bidder. The South Sea Company now amended its offer, added $£_{500}$,000 more in money, and offered four years and a half purchase upon all annuities. which, if all were taken up, would amount to $\mathfrak{f}_{3}, 567,500$,

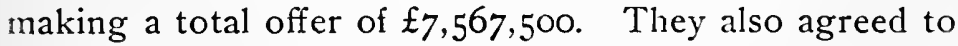
circulate $\mathfrak{E} \mathrm{I}, 000,000$ in exchequer bills gratis, and to pay three per cent. interest for the same. ${ }^{3}$ Notwithstanding the efforts of Walpole, the offer of the company, on the

' Journals of the House of Commons, vol. xix, pp. 246-247.

'Rapin, op. cit., vol. xxvii, p. 359. The bank offered three years purchase on the long and short annuities, which if all were taken up would amount to $£ 2,367,600$, and twenty per cent. upon redeemable debts, which if all were subscribed would amount to $£ 3,180,000$.

"Journals of the House of Commons, vol. xix, p. 248. 
recommendation of Aislabie, Chancellor of the Exchequer, was accepted by Parliament.

In order to carry through this great undertaking, it was necessary that there should be an enormous inflation in the price of the company's stock, and that the subscriptions should sell at high premiums. With the acceptance of the offer, the directors expected to see a great rise in the price of stock, but this, much to the discomfort of the officials, did not take place. Various means were resorted to in order to inflate the price. It was reported that Spain had consented to take Minorca and Gibraltar in exchange for certain places in Peru, the land of gold and silver, and that these would be handed over to the company. This announcement raised the price two hundred per cent., at which figure $£ 2,000,000$ of the original issue were sold. A dividend of ten per cent. was promised on April the twenty-first, and a second subscription was sold at 360 . About this time, the people became frenzied with the fever of speculation, so that by the end of May, the $f$ Ioo stock had risen to $£ 890$, and before the end of June reached $\mathfrak{f}_{\mathbf{I}, 000}$. This outburst of mad speculation was not confined to the South Sea Company, as companies were formed for every conceivable object. ${ }^{x}$ Finally, the South Sea directors obtained from the Lord Justice an order to stop many of these speculative schemes. The irritation thus produced threatened to expose the South Sea Bubble itself. The crash came in the early part of September, when a number of banks failed because they had lent money on South Sea stock and found themselves unable to realize. The stock commenced to decline, and by September the fourteenth, it had declined to $£ 570$ and in a few days to $\mathfrak{f}_{4} \mathrm{OO}$.

'See Wirth, Geschichte der Handclskrisen. 
Scores of goldsmiths and bankers who had lent large sums on the shares now stopped payment and absconded. Many wealthy merchants, stripped of all they possessed, were thrown upon the world penniless, and some of the beggared wealthy men were so broken-hearted that they committed suicide. Thousands who had had the brightest prospects found themselves in the relentless grasp of sudden poverty. The public credit of England was shaken to its foundations, and never before had confidence in the state reached as low an ebb. Public excitement raged to an unparalleled height. With everything pointing to ruin, all eyes were turned to Walpole to save his country. He had from the first opposed the scheme, and now when the country needed him, he willingly offered his services.

Clamors were loud against the directors and officers of the company. Mr. Broderick in a letter to Lord Middleton said that he perceived that the very name of a South Sea man grew abominable in every county. The excitement became so alarming that the King was hastily summoned from his German dominions, but his presence did not restore confidence in the government. The public now anxiously awaited the opening of Parliament on the twenty-fifth of November. The members of the ministry were busily engaged in formulating some scheme for restoring public credit, and it was necessary further to prorogue Parliament until the eighth of December. The position was most critical and great was the despondency of the nation when Parliament met. The King in his speech earnestly besought the House of Commons to consider the most effectual and speedy methods of restoring the national credit and placing it upon a lasting foundation. ${ }^{x}$ Mr. Pulteney moved, in his

${ }^{1}$ Hansard, op. cit., p. 679; or Journals of House of Commons, vol. xix, p. 377 . 
motion for an address of thanks, that the House should, at this critical conjuncture, proceed with all possible care to inquire into the causes of the misfortune and apply the proper remedies for restoring and placing public credit upon such solid and lasting foundation as might effectually give ease to the minds of the people. ${ }^{1} \mathrm{Mr}$. Shippen moved to insert after the words "fixing public credit" the phrase "as far as it is consistent with the honor of Parliament, the interest of the nation and the principles of justice." " His motion, on being seconded by Mr. Bromley, gave rise to a heated discussion. Walpole contended that such a restriction did but ill comport with an address of thanks, which should be in the usual form and should answer in general terms the several heads of the speech from the throne. He declared that he had never approved the South Sea scheme, and was sensible that it had done a great deal of mischief. Since it could not be undone, he thought it the duty of all good men to give their helping hand toward retrieving it, and with this view he had already bestowed some thought on a proposal to restore public credit, which at a proper time he would submit to the wisdom of the House. ${ }^{3}$

In the debate on a motion ordering the directors and managers of the South Sea Company to lay before the House forthwith all the books and papers of the company, ${ }^{4}$ Walpole said that he had spent some time upon a proposal for the remedy of the evil, but was apprehensive that if they went on in such a passionate way, the scheme might be rendered altogether impracticable.

'Hansard, op. cit., pp. 680-681.

'Ibid., p. 68r; or Journal of House of Commons, vol. xix, p. 378.

Ibid., p. 684 .

'Ibid., p. 686; or Journals of the House of Commons, vol. xix, p. 381. 
Therefore he desired that the House would proceed regularly and calmly, lest by entering precipitately into odious inquiries they should aggravate the distemper to such a degree as to render all remedies ineffectual.

Walpole has been harshly criticized for this attitude. He was never revengeful but remained calm and deliberate under the most trying circumstances. His sole aim was to restore public credit and to do so as peacefully and quietly as possible. This passive policy was the main cause for the quick restoration of conficlence in the government. He contended that what was done could not be undone and that the disrupted business relations should be quickly readjusted. His policy of leniency proved to be successful, for in a short time the company was on sound financial ground, the panic had passed over and was regarded simply as a dearly bought experience. For this work, Walpole should be praised rather than censured, for if it had not been for his coolness, the heated passions of the people would have gained the upper hand, and the result would perhaps have been little short of a revolution.

On December the fourteenth, Mr. Pitt complained that the company had not complied with the order of the House, but was assured by Sir Theodore Jansen, one of the South Sea directors, that on the next day some of the papers would be laid before the House. On the following day the managers of the company presented several papers. ${ }^{2}$ After much discussion, the matter was adjourned until the nineteenth, and in the meantime, the managers were ordered to lay before the House several additional papers relating to the company's affairs. On the nineteenth, Sir Joseph Jekyll moved that a com-

'Journals of the House of Commons, vol. xix, p. 385. 
mittee be appointed to inquire into all the proceedings relating to the execution of the South Sea act. Walpole strongly opposed the motion, declaring that proceeding in that manner would take up a great deal of time, and that since the public credit was in a precarious condition, they ought to apply a speedy remedy. ${ }^{x}$ The motion was not insisted upon. Walpole then reported that the execution of his scheme for restoring public credit rested upon a fundamental idea and that he hence thought it proper, before he outlined the scheme, to be informed whether he might rely on that main foundation, that is, whether the subscription of public debts, incumbrances, money subscriptions and other contracts made by the South Sea Company should remain in the present state. The question gave rise to a warm discussion, but the proposal was finally adopted.

On December the twentieth, Walpole, in behalf of a motion that the House agree with the committee in the resolution respecting the South Sea Company, ${ }^{2}$ declared that the South Sea scheme had been of great benefit to England in effecting a method of paying off the debt in a few years by making the annuities for long terms redeemable. This had been done without a breach of parliamentary faith, and if they should now unravel what had been done, they would not only ruin the South Sea Company but would, instead of alleviating, aggravate the present misfortune. ${ }^{3}$ The motion passed without division. The following day Walpole presented his scheme, which was to "ingraft" 4 nine millions of the South Sea stock

${ }^{1}$ Hansard, op. cit., p. 689 .

${ }^{2}$ Journal of the House of Commons, vol. xix, p. 392.

3 Hansard, $o p$. cit., p. 690.

"The capital stock of the South Sea company was $637,802,2035 \mathrm{~s}$. Od. By the bank contract, $\mathcal{L} \mathrm{I} 8,000,000$ were to be taken from the stock of 
in the Bank of England and a like sum in the East India Company, ${ }^{x}$ that is, the old creditors of the government who had exchanged their securities for an equal amount of South Sea stock were now given the privilege of exchanging their stock for an equivalent sum of stock in the Bank of England and the East India Company at a premium of about twenty per cent. Mr. Hutchison and several members made exceptions, but no one offered a better remedy. ${ }^{2}$ Whereupon it was ordered that proposals should be received from the Bank of England and the East India Company for restoring public credit. ${ }^{3}$

After a short recess the House assembled on the fourth of January. On the eleventh, thirteen members were appointed a secret committee of inquiry, and it was ordered that the books and papers of the company, which had been laid before the House, should be referred to it. On the nineteenth a bill which ordered the directors and governors of the company not to leave the kingdom for a year, to give bonds for $£$ roo,o0o with two sureties of $\mathfrak{2 5}, 000$ each as guarantee for complying with the act, and to deliver an inventory of their estates, real and personal, passed the House with a large majority. ${ }^{4}$ This was immediately followed by an act which disqualified the directors and governors from holding office in their company, the East India Company or the Bank of England, and from voting in elections of their own company. ${ }^{5}$ On the twenty-second Mr. Knight, cashier of the company, absconded, and the following day General Ross,

the South Sea company; one-half to be added to the stock of the Bank of England and one-half to the stock of the East India company.
${ }^{1}$ Ibid., p. 692.
${ }^{2}$ Coxe, op. cit., vol. i, p. $25 \mathrm{I}$.

'Journals of the House of Commons, vol. xix, p. 392.
${ }^{7} 7$ Geo. I, c. I.
${ }^{8} 7$ Geo. I, c. 2. 
one of the members of the secret committee, declared that they had already discovered a train of the deepest villainy and fraud that had ever been contrived to ruin a nation. Orders were given to take into custody several of the directors and to seize their papers. Two members who were directors of the company were expelled from the House, and a few days later two others met with the same fate.

On February the sixteenth, the first report of the committee of secrecy was read to the House. It exposed a scene of fraud, corruption and iniquity never before paralleled in the annals of England. ${ }^{r}$ Many of the members of the cabinet were implicated in the most daring schemes of speculation; and ministers and members of the King's household had received gifts of great blocks of stock. The second report was read on the twenty-fifth and more charges were laid against ministers. $^{2}$ The Commons first considered the charges preferred against Charles Stanhope, but he was acquitted. On March the eighth, charges of speculation in the South Sea stock were made against Chancellor Aislabie who, not being able to stand the criticism, had previously resigned. He was found guilty, expelled, committed to the Tower and ordered to make a statement of his estate for the benefit of the company. No sooner was this report received in London than the whole city was in a blaze of bonfires. The losers were anxious to have the severest punishment meted out to those guilty of bringing about the disaster. On the tenth, George Caswell was expelled and committed to the Tower, while on the

'Hansard, op. cit., pp. 7II-739; Journals of the House of Commons. rol. xix, pp. 425-452.

'Ibid., pp. 459-460. 
fifteenth, the Earl of Sunderland was declared innocent of the charges brought against him. The secret committee, after a third report of very little consequence, broke off all further inquiries.

The deranged state of the credit of the South Sea Company made it impossible for the directors to fulfil their engagement for the payment of $£_{4}, 156,306$, which sum was to be paid in four quarterly installments commencing on March the twenty-fifth, I721. ${ }^{x}$ The company petitioned the King and the House of Commons for an extension of the time of payment. On February the eighteenth it was resolved that the time be extended to the twenty-fifth of December, 1722, and that in case of default the money should be taken out of the payment to the company from the Exchequer. It was further resolved that the re-payment of the million loaned to the company in exchequer bills in June, 1720 , be postponed to June, 1722. These were agreed to by the House, and it was ordered that they be added as clauses to the Bank Contract act. ${ }^{2}$ On the twenty-second, the bill for "ingrafting" the stock of the South Sea Company was reported to the House. It provided for the transfer of nine millions of the stock to the Bank of England, and a like amount to the East India Company. With the addition of the two clatuses for the extension of time, it passed the House of Commons, ${ }^{3}$ was sent to the Lords, and afterwards received the royal assent. ${ }^{4}$

On the seventeenth of April, the committee appointed to inventory the estates of the directors and the chief officers of the company, reported to the House that the complete valuation was $£ 2,014,123 . .^{5}$ An act followed,

16 Geo. I, c. 4.

'Sournals of the House of Commons, vol. xix, p. 452.
${ }^{3}$ Ibid., p. 456.
${ }^{4}$ Ibid., p. 483 .
${ }^{3}$ Ibid., p. 513. 
that vested in trustees the power to sell the property, and after the payment to the officials of the allowances made to them, amounting in all to $£_{354}, 600$, to appropriate the remainder to the South Sea Company. ${ }^{1}$

The holders of the national debt who had given up their annuities and in return had subscribed for stock of the company were now thrown into dismay by the fall in the price of the stock and contended that they were not bound by their subscriptions, and it was deemed necessary to settle the dispute by an act of Parliament. ${ }^{2}$ It was enacted that the company should be exonerated from the sum of over four million pounds which as explained above it had agreed to pay the public for the privilege of increasing its stock, and that in lieu thereof, two millions of the debt due to the company from the government should be cancelled in midsummer, 1722 ; that the new capital stock issued in 1720 should be divided among the proprietors or stockholders in proportion to their several interests; that the people who had subscribed for stock and made only part payment, or who had borrowed money on deposit of the company's stock at a very high premium in 1720 , should be released on payment of ten per cent. to the company; that all contracts for any kind of stocks not compounded before September the twenty-ninth, I721, should be void if not entered upon the books before November the first, I72r, and that in the meantime all lawsuits thereon should remain suspended.

At a meeting of the general court of the company, held on September the first, Sir John Eyles, the SubGovernor, said that satisfactory arrangements had been made by the king witl Spain regarding the South Sea

${ }^{17}$ Geo. I, c. 28.

${ }^{2} 7$ Geo. I, sess. 2, c. I. 
trade; moreover that they intended to embark in the Greenland trade; and that the forfeited estates of the late directors, and the ten per cent. on the stock subscriptions [as explained above] were sufficient for discharging the debts of the company and maintaining the credit of its bonds. The affairs of the company were accordingly so adjusted that it was not necessary to make use of the Bank Contract." The "ingrafting" was not seriously considered, and remained a dead letter.

The company found itself unable to repay, in June, I 722 , the million loaned to it by the government in $1720 .^{2}$ By an act of Parliament, the time for payment was extended to June the seventh, I723, and the company was relieved of its contract to pay five per cent. for the same. ${ }^{3}$ At the expiration of the extended time, the debt was paid. In order to raise the credit of the company and consequently to increase the price of its shares, an agreement was entered into, whereby the Bank of England was to buy four millions of its stock. A special act of Parliament gave the company the power to make the sale, ${ }^{4}$ and the capital stock was by the transfer reduced to $£_{33}, 802,203$. During the next session of Parliament, an act ${ }^{5}$ restored to the company the two millions which had been cancelled two years before and in this way the pecuniary advantage which the people were to gain by the South Sea Company's taking over the national debt was lost. The old proprietors or original stockholders, however, made a great gain. The company in taking over the government annuities paid the annuitants cash or gave them the company's stock at

'Rapin, History of England, vol. xxviii, pp. 106-107.

:6 Geo. I, c. 20.

88 Geo. I, c. 20.

48 Geo. I, c. 21 .

g Geo. I, c. 6. 
market value, but had the right to issue stock of par value equal to that of the annuities so taken over. For example, where the company agreed to pay an annuitant $£_{100}$, it gave him cash or stock of the market value of $£_{100}$, which perhaps amounted to only $£_{40}$ or $£_{50}$ par value. The difference was then divided among the original stockholders as a surplus.

The same act of 1725 made a considerable change in the character of the company's stock. It was deemed necessary to lessen the powers of the company and to put a check to its trading speculations, and as a consequence, by this act, its entire stock was divided into two parts, one of which was to remain as the South Sea Company's capital, and to have the advantage as well as the risk of its trade together with its allowances for expense of management, while the other part was converted into annuities at five per cent. till midsummer I 727, and four per cent. thereafter. The first half was to be called the South Sea Company's trading stock, and the second the South Sea annuities.

In 1727 the general court of the company agreed to discharge all the borrowers of money on its stock in the year 1720 , who had not already repaid the same, on condition of their paying back ten per cent. of the money borrowed. The same year an act of Parliament ordered that the net produce of the estates of the late directors should be applied solely for the benefit of the company." The following year Parliament enacted that $£_{500,000}$ should be paid from the sinking fund to the company, with the understanding that it should sink that amount of the undistributed stock forfeited by the late directors. ${ }^{2}$ Two years later Parliament paid one million sterling out

'13 Geo. I, c. 22.

${ }^{2}$ I Geo. II, sess. 2, c. 8. 
of the sinking fund to the company, and the following year it paid another million. ${ }^{2}$ This latter sum was directed to be divided among the annuitants, and each accordingly received six and a quarter per cent. of his holdings. In 1732 Parliament ordered that another million be paid to the company from the sinking fund. ${ }^{3}$ This sum was intended to redeem an equivalent amount of that part of the capital stock, known as the South Sea annuities, explained in the preceding paragraph. The next year a million was paid to the company from the same source and an equal amount of the annuities redeemed.4 Another act of that year made a still further division of the trading stock. 5 This, at this time, amounted to $\hat{E}_{14}$,65I, I03, which after midsummer, I733, was to be divided into four equal parts, three of which were to be called the new South Sea annuities, and to have no share in the profit or loss by trade or management with the exception of the four per cent. annuity payable by the public, the remainder being intended to remain as a trading stock, and to have the whole profits, as well as the residue of the annuity, paid by the government. ${ }^{6}$ Thus the capital of the company was now divided into three parts, the old South Sea annuities, the new annuities and the trading stock proper, which now formed by far the smallest part. In I 736 it was ordered that a million should be paid from the sinking fund to redeem a million of the new South Sea annuities, ${ }^{7}$ and the following year the company received a like amount for the same purpose. ${ }^{8}$

Throughout the administration Walpole had at all

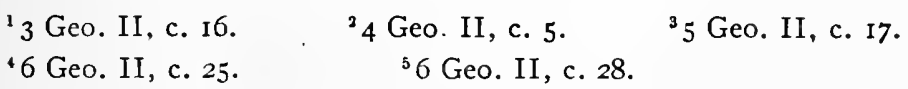

"The South Sea annuities amounted to $£_{15}, 651,099$.

' 9 Geo. II, c. 34 .

${ }^{8}$ Io Geo. II, c. I7. 
times especially favored the company. Although there had been a great disruption of credit yet we must not censure its officials too severely, because the speculative fever seemed to have been in the very air. Walpole by his calmness and financial ability restored credit without any great break in the company's affairs. Nevertheless, with his policy of leniency toward the officials, he could not save them from disgrace and confiscation of property. He felt that there were others just as guilty as they, and that they should not have the whole blame placed on their shoulders. Many have censured Walpole for his liberality toward the company. Yet he, above all others, realized what the result would be if it were forcibly dissolved. The company had done a great service to the government in reducing the annuities, and if it could be assisted for a few years, it would be on a sound financial basis, and then would no longer need aid. Walpole, at the same time, took care to lessen the power of the officials over the stock, and consequently made it more secure for the creditors. By his last restriction ${ }^{1}$ the amount of stock that could be used for trading, and therefore for speculative purposes, was made to be such a small quota of the whole that in future there was no fear of another financial panic through speculation on the part of its officers. We herewith append a statement, computed from acts of Parliament, of the national debt held by the South Sea Company in $174 \mathrm{I}$.

THE STOCK OF THE SOUTH SEA COMPANY-174I.

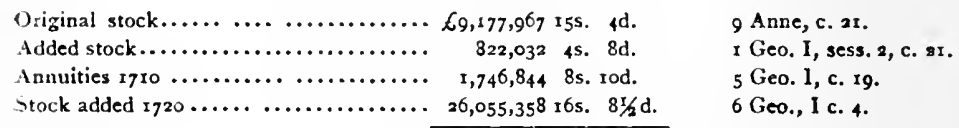

Total .......................

'Vide, D. 57; 6 Geo. II, c. 28. 
STOCK REDEEMED AND SOLD.

Sold to the bank $. . \ldots \ldots \ldots \ldots \ldots \ldots \ldots \ldots £_{4}, 000,000$

Redeemed by the government .......... 500,000

Redeemed by the government from S. F.. $\quad x, 000,000$

Redeemed by the government from S. F.. $\quad x, 000,000$

Redeemed by the government from S. F.. $x, 000,000$

Redeemed by the government from S. F.. $\quad 1,00,000$

Redeemed by the government from S. F.. I, $1,00,000$

Redeemed by the government from S. F. $\quad x, 000,000$

8 (ieo. I, c. 2 r.

I Geo. II, sess. a, c. 3.

3 Geo. II, c. 16 .

4 Geo. 1I, c. 5.

5 Geo. II, c. 17 .

6 Geo. II, c. 25.

9 (ieo. II, c. 34 .

ro Geo. II, c. I7.

Total

$£ 10,500,000$

Original and added stock.............. $\swarrow_{37,802,203} \quad 55.61 / 3 \mathrm{~d}$.

Stock sold and redeemed .............. $10,500,000$

Capital stock $1741 \ldots \ldots \ldots \ldots \ldots \ldots \ldots, 27,302,203 \quad 55.61 / 2 d$.

The original rate of interest was six per cent., which was reduced in $I 7 I 7$ to five, and in 1725 to four per cent.

This is perhaps the best place to refer to a very important financial reform, viz., the change made in the payment of exchequer bills. This form of paper credit was devised by Montague in I696. to serve as a substitute for casli during the period of recoinage. He issued bills on the exchequer, and at the same time contracted for their circulation for ready money, on demand. In I706, the Bank of England undertook their circulation at a certain premium. They continued to be issued yearly by the government for obtaining part of the money necessary for current expenses. The rate of interest paid depended on the public credit and on the ratio between the demand for loans and the supply of money. It was customary to raise the grant of the land and malt taxes in this way. The taxes would be gradually paid into the exchequer. but the bills would not be cancelled until the amount borrowed on the taxes had been collected. As a result, during the greater part of the time, there was a large sum of money in the exchequer not drawing interest, while the government was at the same time paying interest on the bills this was to redeem. The only way 
to remedy this and to save the government annually a large sum in interest, was to redeem the bills as the money accumulated. This desired change was introduced by Walpole in 1723 , when an act of that year provided for the issuing of one million in exchequer bills. It was required that they be numbered arithmetically and bear interest at two pence per day; the bills were to be gradually paid off and cancelled by the future produce of the sinking fund. ${ }^{x}$

The Bank of England watclied with a jealous eye the founding and growth of the South Sea Company. After the success of the company with the Lottery Annuities in i719, as has been explained above, the jealousy greatly increased and led to a spirited competition for the assumption of the national debts in 1720 . Extravagant bids were made by each institution, but fortunately for the bank, the offer of the South Sea Company met with most favor. Two years later, the bank came to the assistance of its rival by buying four millions of its capital. In 1725 it was enacted that the sum of $£_{3,775,027}$ due the bank should after midsummer, 1727 , be redeemable upon payment of the principal or of any proportionate part not less than $£_{500,000}$ at a time, and that the interest should be reduced to four per cent. ${ }^{2}$

On two occasions the bank loaned the government large sums of money. A tax on coal entering the port of London was first granted in 1685 for the building of churches in the city, but by an act of I719, this use was abolished and the produce of the tax was taken for public services. ${ }^{3}$ An annuity of $\mathfrak{E}_{70,000}$ was thus obtained, upon which, in 1728 , the bank agreed to loan the govern-

${ }^{1} 9$ Geo. I, c. 5 .

II Geo. I, c. 9.

${ }^{3}$ I James II, c. 15; 5 Geo. I, c. 9. 
ment $f_{1,750,000 .}$ The following year the bank loaned the government $£_{1,250,000}$ upon an annuity of $\mathfrak{f}_{50,000}$ established by an act of Parliament. ${ }^{2}$ By the same act provision was made to pay the bank, out of the sinking

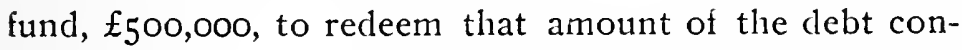
tracted in $17 \mathrm{I} 7$. In 1738 , a million was paid the bank from the same source, to be applied to the redemption of the same loan, and the stock of the bank was reduced to

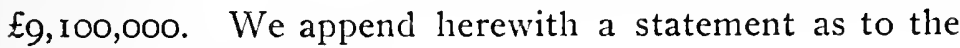
stock of the bank in $1741 .^{3}$

THE STOCK OF THE BANK.

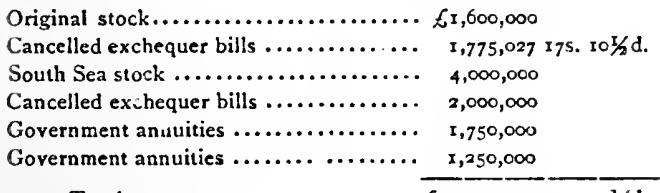

Total

$6 \times 2,375,027 \times 7$ s. $101 / 2 \mathrm{~d}$.
STOCK REDEEMED.

From sinking fund ................ £

From sinking fund ............... $1,275,027 \mathrm{I} 7 \mathrm{~s} .10 \mathrm{l} / 2 \mathrm{~d}$.

From sinking fund.

$1, \infty 00, \infty 00$

$\ell_{3,275,027} 17 \mathrm{~s} .10 \mathrm{1} / 2 \mathrm{~d}$.

Total

Total stock of bank E12,375,027 17s. I0I/2d.

Total stock redeemed . ........... $3,275,027 \mathrm{r} 7 \mathrm{~s} . \mathrm{ro} / 2 \mathrm{~d}$.

Capital stock r74r ................ 9,100,000
7 Anne, c. 7.

8 Geo. I, c. 21 .

3 Geo. I, c. 8.

I Geo. 1I, sess. 2, c. 8.

a Geo. 1I, c. 3 .

I Geo. II, sess. 2, c. 8.

2 Geo. II, c. 3.

II Geo. I1, c. 27.

The original stock bore interest at six per cent. The interest was reduced in $I 7 I 7$ to five, and in 1725 to four per cent.

Returning to the sinking fund, we find the annual surpluses gradually increasing. At midsummer, 1727 , the interest on the national debt was reduced from five to four

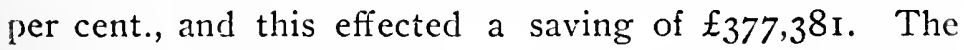
House of Commons, in its account of national debts, presented April the eighth, I728, declared that the yearly

'I Geo. II, c. 8.

$2_{2}$ Geo. II, c. 3 .

${ }^{3}$ This table has been computed from Acts of Parliament. 
surplus amounted to fI.200.000." Price states that the a:erage pament into the fund irom 1727 to 1732 was EI.2I2.000 per annum." Thus. in a decade. the annual surplus had nearly quadrupled. When there was an urgent need ior moner. and Dornowing became necessary in orcer to met curent expenses. such a large sum could not long be secute trom the grasp of financiers. Even betore the report of the House o: Commons in 1728 , the fund had been given as security and had been encroached upon. In I/22. it was mace the collateral securi: io the inters: on one millon oi exchequer bilis." and this pared the way tor more direct encroachment. Two years later. Higr I4 were taken from the insd to mate good the loss to the treasury from the reduction in wiue of gold coin. in provicing a revenue tor King George ine Second. Waipole on Fuly the third. I727, mored that the entire income ot the ciril list. amounting to $\$ 800.000$. be settled on the King during his hie.: This was a hunced thousand pounds more than was granted to Geogge the Fist. and the increase was a surpius mich tad been appooprated to the sinting iund. Mr. Snipper. in a speech. declered that this was an encroacrment upon the sthking kud. which the thought had been a sacred disposition reserved for the gradual discharge oi the national debt and stated that it was a sacrilege to divert the least pert on any preterse irom its original uses. It was surprising to him that the honorble genteman was destroting his own

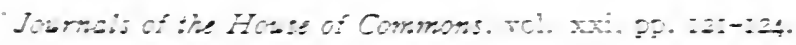

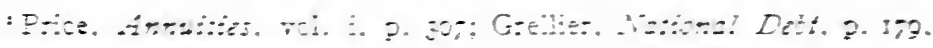

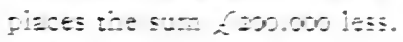

sz G $=0$. I. c. 20 .

$\therefore: G=0$. I. c. 20 .

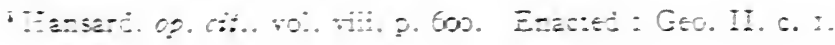


darling project. ${ }^{x}$ Walpole made no answer to these arguments at this time.

The next encroachment was made in raising $\mathfrak{f}_{1,250}$,ooo for the public service in $1729 .^{2}$ Walpole claimed that the sinking fund was in such a flourishing state that it could bear the interest of this loan, and that there would be no need of imposing new taxes. The opposition objected, and moved that the House raise the supplies without creating new debts upon any fund. ${ }^{3}$ But very little interest was taken in the motion, and it was lost. It was now apparent that Walpole intended to divert the sinking fund from its original purpose and use it as a means of raising revenue. But not being in a position to take money openly from the fund, he was compelled to resort to circuitous ways. In I730 Parliament ordered that in future the East India Company's annuity, charged to the salt and stamp duties, be paid out of the surpluses of the aggregate fund, which surpluses formed part of the sinking fund. ${ }^{4}$ The salt duties had been abolished and the stamp duties were now free and liable to a new appropriation. The year following they were accordingly made a fund for paying the interest on a new loan of $E_{I}, 200,000.5$

In I732, Walpole reduced the land tax to one shilling, and in order to compensate the loss of revenue occasioned by this reduction, he revived the salt duties. The question arose as to whether these taxes should not again be appropriated to the sinking fund. If not, it would be a dangerous precedent to abolish taxes belonging to the fund one year and to renew them for other purposes the

${ }^{1}$ Hansard, op. cit., p. 604.

$$
22 \text { Geo. II, c. } 3 \text {. }
$$

- Hansard, op. cil., p. 680.

${ }_{4} 3$ Geo. II, c. 20.

${ }_{4}^{5}$ Geo. II, c. 9 . 
next. It would defeat the purpose of the fund, which would soon be exhausted. Nevertheless, with the aid of the landed interests the salt duties were renewed and used as a fund for borrowing $\mathfrak{£}_{500,000}$ for current expenses. In order to continue the land tax at one shilling for 1733 it was necessary to raise the $£_{500,000}$ deficit by other means. That year Walpole intended to bring forth his excise scheme, which he thought would render it possible to continue the land tax at one shiliing. The important question was to provide the half million pounds for current expenses. A new tax had to be levied or a new scheme devised for raising this amount. The sinking fund, with its millions, was a great temptation, for a new tax would be unpopular, and the landed interests would support any measure that would lessen their taxes. The country was prosperous and the people paid little attention to the national debt or the sinking fund. Walpole accordingly moved that the land tax should continue at one shilling, and that $\mathfrak{f}_{500,000}$ should be taken out of the sinking fund and applied to current expenses. ${ }^{x}$

This aroused a warm discussion in both Houses. Walpole, in support of his motion, declared that the public revenue ought to be raised according to that method which was the least burdensome to the people. and that by this method he would provide for a great part of the current expenses of the year without levying any new tax on the country. The case of the creditors of the public was now far different from what it had been, and whereas they were previously anxious for payment of their loans, the competition now was for the last one to be paid; in this light, the payment of loans 
would be considered by many as a hardship. This motion he thought should be agreed to, in that it would give ease to the landed interests. ${ }^{1}$ For the opposition, Pulteney contended that the landed gentry should consider it an indignity offered to them, as if the payment of a shilling in the pound on the land tax was of any moment in comparison with the welfare of the country; and he contended further that the sinking fund, that sacred deposit for extinguishing debts and abolishing taxes, should never be touched. ${ }^{2}$ Walpole, in answer, said that he remembered the time when the establishment of a sinking fund was treated as a monstrous project, and that he was then obliged to father it; but no sooner was it found to be a good thing than other gentlemen endeavored to rob the real father, whoever he was, of the glory of paternity. The sinking fund was established for the payment of the debts of the nation, but it was nevertheless left subject to the disposal of Parliament, and if upon any occasion it should appear that a part of it might be more profitably applied to some other use, the legislature had certainly a power to apply it in the manner which they should judge to be most for the public good and for the interest of the nation in general. ${ }^{3}$ Sir John Barnard said that the welfare of the nation was more important than that of the landed interests, and that the scheme would be contrary to the interests of the nation in general. The unwillingness of the creditors to receive payment was due to the fact that they received a higher rate from the public than elsewhere. ${ }^{4}$ Sir William Wyndham followed and said that he held the sinking fund in the greatest veneration, and

${ }^{1}$ Hansard, op. cit., p. r202.

'Ibid., p. I204.

'Ibid., p. 1205.

'Tbid., p. 1208. 
looked upon it as a sacred fund appropriated to relieving a nation from the load of clebts and taxes under which it groaned. ${ }^{x}$ These arguments did not alter the opinion of the Honse, and Walpole, aided by the moneyed and landed interests, carried his motion by a large majority.

In the House of Lords the opposition was as great as in the Commons. Lord Carteret declared that the creditors of the public had a right to the sacred fund, called the sinking fund; that the whole people of England had a right to have it duly applied, because it was by such application only that they could get free of the grievous taxes which lay so heavily upon the poor and were such a clog to the trade and the manufactures of the nation, and that therefore the application of the fund to any other use was robbing the public creditors of their right and was doing an injustice to the whole people of England." As in the Commons, the motion, however, received a large majority.

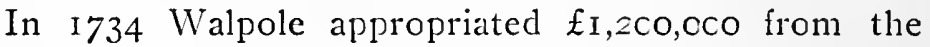
sinking fund for current scrvices. ${ }^{3}$ In the House of Lords the protest by the disscnting lords stated that taking away in this manner the whole produce of the sinking ftind had a tenciency, as they apprehended, to destroy Parliamentary credit as well as the national faith. ${ }^{4}$ But as in the Commons, the landed gentry had their own interests at stake, and carried the bill by a large majority. ${ }^{5}$ In 1735 the sinking fund was not only diverted but anticipated. It was enacted that before March the twenty-fifth, I 736 , a million should be issued

'Hansard, op. cit., p. 1212.

"History and Froceedings of the House of Lords (Lordon, 1742), vol. iv, p. 155.

${ }^{3} 7 \mathrm{Geo}$. II, c. I2. 'Ibid., vol. iv, p. 287.

${ }^{3}$ The vote was 94 in favor and $5 \mathrm{I}$ against. 
out of the fund for current services, and that the growing produce after that time should be mortgaged for raising by loans at four per cent. what should be wanting to complete that sum.' The following year the sinking fund was mortgaged for $£ 600,000$, to be raised by loans at three per cent. ${ }^{2}$ The arguments given for this loan were the continuation of the land tax at two shillings and the unwillingness of the public creditors to have their debts redeemed.

In I737 a new method was adopted for diverting the fund. The old duty of thirty-six shillings per barrel on siveets was repealed; a new one of twelve shillings was imposed ${ }^{3}$ which made a fund for making a loan of $f_{500 \text {,- }}$ ooo. The new duty should not have been so used, because the old one had been appropriated to the South Sea Company, and the surplus paid into the aggregate fund. 4 It was thus an encroachment on the sinking fund to which the surplus of the aggregate fund had been appropriated. 5 In I 738 the estranged relations with Spain made it necessary to raise a large revenue. An act of Parliament appropriated a milion and a half from the sinking fund for the supply of 1738 , and gave the King power to raise by loans or exchequer bills, upon the credit of the fund, the further sum of a half million for the same use. ${ }^{6}$ Still further encroachments were made in I739, when Parliament empowered the treasiry to take, before midsummer, I739, a half million out of the fund and after that date to borrow for current expenses half a million more upon its growing produce. ${ }^{7}$ During 1738

'8 Geo. II, c. II. A heated discussion tcok place in the House of Lords. Hisiory and Frocedings of the House of Lords, vol. iv, pp. 489-514.

29 Geo. II, c. 34 .

${ }^{3} 3$ Geo. I, c. 7 .
${ }^{3}$ Io Geo. II, c. I7.

'II Geo. II, c. 27.
4 I Geo. I, sess. 2, c. I2.

i I2 Geo. II, c. I9. 
and 1739 , the people were so incensed over the reported cruelties of Spain in the new world, that they paid little attention to the perversion of the fund. In I 740 a million was granted from it for the service of the year, and the King was empowered to raise the further sum of $£ 200,000$ out of its growing produce. The treasury was empowered to borrow money upon the credit of the growing produce of the fund in case its receipts did not come in fast enough to meet current expenses. ${ }^{x}$ The following year Walpole took another million from the sinking fund in order to meet the extra expenditure of the year. ${ }^{2}$

Owing to the fact that many writers have unmercifully criticised Walpole for diverting the sinking fund, let us see whether or not he was justified in his action. Sir John Barnard warned him that he was drawing upon himself the curse of posterity, while later on Dr. Price declared that there thus expired after an existence of a few years the sinking fund, that sacred blessing (as it was once thought) and the nation's only hope. ${ }^{3}$ It must not be forgotten that a financier, in case of a deficit, must raise money where it will be the least felt and cause the least murmur. Walpole in 1732 lowered the land $\operatorname{tax}$ to one shilling, and in making the reduction, he was thoroughly convinced that he was giving relief to the class that deserved it. In order to make up the deficit, it was necessary to revive the salt tax. The following year he intended to bring forth his famous excise scheme, and he felt that the saving effected would make up the greater part of the deficit. If the land tax were to remain at one shilling for $\mathrm{I} 733$, it was necessary

'13 Geo. II, c. 23.

${ }_{\text {I4 }}$ Geo. II, c. 4 I.

Price, Annuities, vol. i. p. 306 . 
to raise the $\mathfrak{1}_{500,000}$ by other means. The sinking fund with its millions was a great temptation. He had on several occasions indirectly encroached upon it. Walpole knew that taking the half million from the fund would cause less murmur among the landed interests than raising the land tax. He wished the land tax to remain at one shilling for the year, in order to use it as a strong argument in winning greater support for his excise scheme. On a careful view of the circumstances of the times, and in consideration of the points adduced on the following page one can not but feel that Walpole was justified in appropriating the half million for current services.

The Excise Scheme failed, and in 1734 the land tax was raised to two shillings, but over two millions were needed to meet current expenses. Walpole raised a million by continuing the salt duty, and it was a case of loan, new duty or sinking fund for the remainder. The question was how to raise the million in the way that would cause the least burden on the people, who were already complaining of their taxes. An extra shilling on the landed interests would cause increased opposition from that class, while nothing would be gained by borrowing and paying off delsts from the sinking fund. If the fund were allowed to accumulate to any great extent, the nation would by this method lose considerable interest, so that if money were to be borrowed and afterwards paid from the sinking fund, the question obviously presents itself: why not take the money directly? Walpole in doing so pursued the policy that caused the least criticism and the one that least affected the people at large.

The following year, the deficit was greater, and Walpole could have raised the land tax without much opposition, because the country was aroused against Spain. 
Again he wished to secure the good will of the landed interests, so that in case of war he could draw upon them for the means for carrying on the struggle. This proved the case, because when the war did come the landed gentry, without a murmur, paid the land tax of four shillings. From this to the end of his administration, the sinking fund was not only anticipated, but used as security for borrowing money. The fund, though diverted from its original purpose, served to carry England through a period of deficits; and had it not been diverted, there would have been burdensome loans, or taxes which would have caused discontent and dissatisfaction, while nothing would have been gained by new loans and paying debts from the sinking fund. Though the national debts were not paid off as rapidly as expected, the fund prevented new loans from being contracted. We herewith append a statement computed from acts of Parliament of the different sums taken by Walpole from the sinling fund for the services of the government.

For current expenses, $1733 \ldots \ldots \ldots \ldots 500,000$

For current expenses, $1734 \ldots \ldots \ldots$ I, 20 $\ldots$,000

For current expenses, $1735 \ldots \ldots \ldots$ I, 000,000

For current expenses, $1738 \ldots \ldots \ldots$ I,500,000

For current expenses, I $739 \ldots \ldots \ldots . \quad 500,000$

For current expenses, $1740 \ldots \ldots \ldots 1,000,000$

For current expenses, I74I........ I,000.000

Total...............
6 Geo. II, c. 25 .

7 Geo. II, c. I2.

8 Geo. II, c. II.

I I Geo. II, c. 27.

I2 Geo. II, c. I9.

13 Geo. II, c. 23 .

14 Geo. II, c. 4 I.

BORROWED ON FUND FOR CURRENT EXPENSES.

For current expenses, I $736 \ldots \ldots \ldots \ldots 600,000$

For current expenses, $1738 \ldots \ldots \ldots \ldots \quad 500,000$

9 Geo. II, c. 34 .

For current expenses, $1739 \ldots \ldots \ldots . \quad 500,000$

I I Ger. II, c. 27.

For current expenses, I $740 \ldots \ldots \ldots . \quad 200,000$

I2 Geo. II, c. I9.

Total................ £ $1,800,000$

I3 Geo. II, c. 23.

Total appropriated frcm the sinking fund for current services $£ 8,5 \mathrm{co}, \mathrm{ccc}$, I733-1741. 
During the years 1736 and 1737 , the country enjoyed the greatest prosperity. Money was plentiful and interest low; the three per cent. stock selling at 107, the highest price it reached. Here was a great opportunity for some one to bring forth a scheme for the reduction of interest on the four per cent. stock. Accordingly, on the twenty-first of March, I737, Sir John Barnard moved that the King be empowered to raise money, by the sale of either annuities or loans at a rate not exceeding three per cent., to be applied toward redeeming the old and new South Sea annuities. In support of his motion, he said that the three per cent. stock sold at a premium and it would be an unpardonable neglect not to take advantage of this fact to lower the interest on the national debt. There were few who bought the stock at a premium, who would not be willing to lend money to the government at the same rate, if books of subscription were opened for that purpose, with an assurance that no pait of the principal should be paid off for fourteen years. ${ }^{x}$ The motion, which gave rise to a long and tedious debate, was favored by many of the landed gentry but opposed by the moneyed classes. Finally, it was moved and carried that the further consideration of the matter should be deferred for a week. The scheme aroused a storm of indignation among the numerous annuitants and the moneyed classes in general, who declared that a great amount of the stock of the South Sea Company was held by widows and orphans, and that a reduction of interest would mean a great suffering to them. On the following day, it was ordered that an account be laid before the House of the amount of old and new South Sea annuities held by executors, administrators and trusts. ${ }^{2}$

'Hansard, op. cit., vol. x, pp. 74-93.

Tournals of the House of Commons, vol. xxii, p. 819 . 
As yet Walpole had taken no part in the discussion, although there was an impression in Parliament that he favored the scheme. The wealthy men had loaned him large sums of money for governmental services at three per cent., and it was not good policy to have them arrayed against him. From the time that he saw the enmity which the measure aroused and the clamors which it excited among the creditors of the government, he determined to use all his power to defeat the scheme. During the week the ministerial papers were filled with criticisms. The Whitehall Evening Post made an earnest appeal to the feelings and passions of the people in describing the measure as one tending to ruin trade, to depopulate the capital, to impoverish widows and orphans, to reduce the farmers to day laborers and the sons of gentlemen and noblemen to farmers. ${ }^{1}$ On the day appointed for the further consideration of the measure, Sir John Barnard used all the powers of a politician to win support to his scheme. He estimated that the annual surplus paid into the sinking fund would amount to $\sum_{\mathbf{I}}, 600,000$; he proposed with half of this to abolish many of the duties that lay heavily upon the poor, and to apply the remainder to redeem the annuities which then bore an interest of three per cent. ${ }^{2}$ This weakened his measure, because if he had been content with the lowering of the interest it would have been regarded as a great national benefit. He had not taken special care in the preparation of his speech, and many of his statements were proved fallacious and illusory. This exposure greatly detracted from the former popu-

${ }^{1}$ Coxe, op. cit., vol. ii, pp. 410-411.

'Hansard, op. cit., vol. $x$, pp. 155-165; also more fully explaincd ibid., pp. 74-93. 
larity of his measure and won many over to the opposition. Nevertheless, on April the twenty-second, the bill was presented to the House, and a week later was read a second time. ${ }^{2}$

Walpole made a vigorous speech against the measure, declaring that he never had any hand in the scheme, either in its original formation or in any shape in which it had since appeared. The measure he thought was founded on plausible assumptions, but the method proposed was inadequate, and the time was not ripe for such a change. There were twenty-three thousand persons who would be affected by the proposed change ; upwards of seventeen thousand held stock not exceeding a thousand pounds, and these small stockholders would be much distressed by so unexpected a reduction in their income. He further stated that his scheme was entirely different from this one. His was optional, whereas this was compulsory; his laid the foundation, while this reversed the whole system of the sinking fund. This plan was intended to lock up that fund for several years, and during that time all reductions of interest would be prevented, all abolition of taxes rendered impracticable, and a necessity imposed of laying fresh burdens in case of emergency. It could not benefit the present generation, and its salutary effects would principally be confined to those who were yet unborn. ${ }^{2}$ This clever attack caused the defeat of the measure, for the motion for commitment which followed was lost by a large majority. The news of the defeat was received with great joy by the people. Horatio Walpole states that a general illumination took place in the city, and that the mob was with

'Jourrals of the IIouse of Comsions, vol. xxii, p. 860 .

${ }^{2}$ Hansard, op. cit., vol. $x$, pp. $182-186$. 
difficulty prevented from pulling down and setting fire to the house of Sir John Barnard."

The measure aroused great indignation among the people, and if it had passed, would have greatly increased the opposition to the government. Horatio Walpole in a letter dated April the twenty-ninth, I739, states that the unpopularity of those concerned in the plan was so great and the popular resentment so violent, that the time had not arrived for the enactment into law of the right of redemption. ${ }^{2}$ Relations with Spain were somewhat estranged, and Walpole was not desirous of any increased opposition at home. Again, if Barnard's scheme had become law, it would have tied up the sinking fund, which would then have not been available for current expenses. Walpole had adopted the principle that it was better to appropriate the fund than either to levy new taxes or to raise new loans. Barnard's scheme would have put an end to such a policy, and its defeat was the safest and best thing for the nation at large.

Finally, we must consider the ways and means for raising revenue. This tests the inventiveness and ingenuity of the financier. The system of finance that he adopts must raise the revenue without unduly burdening the people or interfering with the industry and the commerce of the country. But we must bear in mind that the unpardonable sin of every financier is the failure to find money. The budget was yet unknown and elasticity of the revenue little developed. Let us review the system of Walpole and see if he was successful in raising money without increasing the burdens of the people or hampering the industries of the country.

${ }^{1}$ Coxe, Memoirs of Horatio Lord Walfole. Letit: of HLotio Watpole to the Princess of Orange.

: Coxe, ibid. 
When Walpole came into power all taxes but those on land and malt were allotted to specific purposes and the surpluses paid into the sinking fund. The pay of the army and the navy, the plantation and the incidental expenses came out of the land and malt taxes. In times of peace, and under normal conditions, these balanced about evenly. The malt tax was, at first, $£$ joo,ooo per annum, and the land tax at two shillings in the pound yielded $f_{1}, 000,000$. If any deficiency occurred in other allotments, or any emergency expenses arose, it became necessary to increase these taxes or to raise the money by other methods. In 1725, the malt tax was extended to Scotland, and an additional sum or $£ 50,000$ yearly was obtained. ${ }^{x}$ The rate was now so high that it could not be increased without much murmuring. The popish plots in 1722 increased the expenses for the year. Walpole, in 1723 , levied a tax on papists, ${ }^{2}$ declaring that they should pay for the extra expense which the plots had caused the country; and raised $\mathfrak{E}_{100,000}$ from this source.

The years 1723,1724 and 1725 were years of peace, and the reventie from the land tax at two shillings, together with the malt tax, proved ample for the current expenses. In 1726 Walpole decided to cancel $\AA_{990}, 0 \mathrm{co}$ of exchequer bills, and the deficiencies from the preceding year amounted to more than $£ 260,000$. This extra amount had to be raised without interfering with the prosperity of the country or imposing any extra burden on the people. $\mathfrak{E}_{\mathrm{I}, 000,000}$ were secured by means of a lottery, ${ }^{3}$ and $\mathfrak{L}_{500,000}$ were provided for by a loan on a duty, imposed on retailers of beer in London and Westminster. ${ }^{4}$ The following year the country was aroused by the pros-

\footnotetext{
' II Geo. I, c. 8.

${ }^{3}$ I 2 Geo. I, c. 2.
}

${ }^{2} 9$ Geo. I, c. I8.
"12 Geo. I, c. 12. 
pect of a war with Spain, and the army and the navy were

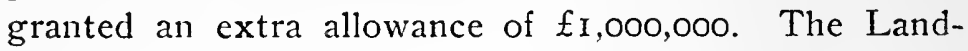
grave of Hesse received a subsidy of $£_{170,000}$ and $£_{50}$,ooo for keeping men in the field. The deficits amounted to over $\mathfrak{2}_{275}, 000$. Thus it was necessary to raise $\mathfrak{E}_{\mathbf{I}}$,500,000 of extra revente. We must remember that the best-arranged system of finance is unable to meet without strain the exigencies of war. The great question is to secure adequate sums at once, and this must be done without unduly affecting the political conditions, and so as to avoid causing discontent. The prospect of war made the landed gentry bear without murmur an extra tax of

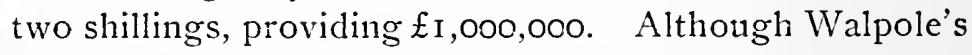
interests were with the landed class, and his desire was to ease them as much as possible, it was necessary for him to be very diplomatic, because they were a great resource to draw upon in time of danger. Furthermore he raised $£_{370,000}$ by loans charged upon the surplus moneys of the cluties on coal." The extra expenditure was thus provided for without a murmur, and with no additional burden upon the shoulders of the manufacturer or the poor man.

By the beginning of the year 1728 the war scare had partly subsided. The extra expenses for the army and the navy were $f_{450}, 000$, and the keeping of 12,000 Hessians in the field adcled $\mathfrak{E}_{23} \mathrm{I}, 000$ more. Sweden received a subsidy of $\mathfrak{f}_{50}$,000 and Wolfenbïttle $\mathfrak{f}_{25}, 000$, while the extra stores at Gibraltar cost $\mathfrak{E} \$ 0,000$, and the deficits added $£ 280,000$ more. Old loans to the amount of $E_{193,000}$ required payment, and $\mathfrak{E}_{500,000}$ of South Sea annuities were to be redeemerl. Exchequer bills to the value of $\mathfrak{E}_{33} 8$,80o were to be cancelled, and $\mathfrak{1}_{500,000}$ of 
seamen's wages were to be paid. These made necessary a total of over $\mathfrak{1}_{2,500,000}$ of extra revenue. The land $\operatorname{tax}$ was assessed at three shillings, which gave $£_{500,000}$ of this amount. A sale of $\mathfrak{E}_{\mathrm{I}, 750,000}$ of annuities was made to the Bank, ${ }^{2}$ and the sum of $\mathfrak{1}_{500,000}$ for seamen's wages was raised by exchequer bills. ${ }^{3}$ No matter how great the emergency or need of money, Walpole had always been equal to the occasion, and secured the amount required with apparent ease and little complaint. We must note that with every loan that was made, Walpole paid off, if possible, some national debt or cancelled exchequer bills. It was his aim to reduce the debt as longas it did not interfere with the national welfare. He did not believe in burdening the people with extra taxes in order to pay the debt of the nation more rapidly.

For the year I 729 the army and the navy were granted an extra allowance of $£_{420,000,}$ and the cost of the 12,000 Hessians added $\mathfrak{2}_{241}$, o00 more, while Sweden received a subsidy of $£_{50,000}$ and Wolfenbüttle $£_{25}, 000$. Exchequer bills to the amount of $£_{500,000}$ were to be cancelled, and the deficit was $\mathfrak{f}_{280,000} \mathfrak{f}_{1,250,000}$ were obtained by the sale of annuities to the Bank, ${ }^{4}$ and the land tax was continued at three shillings, which gave the extra $£_{5} \mathrm{co}$,ooo, needed. 5

The treaty of Seville restored peace, and in 1730 the army and the navy received their normal appropriation. ${ }^{6}$ The Hessians received $\mathfrak{f}_{24} \mathrm{I}, 000$, and extra repairs to the navy added $f_{120,000}$ more. The deficits were $£_{1} 80,000$, Wolfenbüttle was paid $£_{25}, 000$, and incidentals amounted

'I Geo. II, sess. 2, c. 5 .

'I Geo. II, sess. 2 , c. 8.

s Geo. II, sess. 2, c. 9.

2 Geo. II, c. 3 .

${ }^{3} 2$ Geo. II, c. 4 .

- Normal appropriation for the army was $f_{1} \sigma_{5}, 000$, and for the navy \&5 20,000 . 
to $£_{35,000}$. The extra revenue required was over $\mathfrak{f}_{600,-}$ ooo. The East India Company was compelled to pay $£ 200,000$ for the renewal of its charter, ${ }^{\mathrm{x}}$ and the sale of $\mathfrak{f}_{550,000}$ of exchequer bills ${ }^{2}$ allowed Walpole to reduce the land $\operatorname{tax}$ to two shillings. ${ }^{3}$ For the year I73I the Hessians were paid $£_{24} \mathrm{I}, 000$ and Wolfenbüttle a subsidy of $£_{25}, 000$. Deficits were $£_{1} 75,000$ and extra expenses amounted to $f 65,000$, while exchequer bills to the amount of $£_{5} 10,400$ were to be cancelled. The increase of the revenue amounted to more than $\mathfrak{E}_{\mathrm{I}, 000,000 \text {. The land }}$ $\operatorname{tax}$ was continued at two shillings, and the required revenue of $£$ I,200,000 was raised by annuities and a lottery. ${ }^{4}$ The year following, it was not necessary to pay for the support of the Hessian troops nor to pay a subsidy to Wolfenbüttle. The navy was reduced to two thousand men, and $\mathfrak{f}_{104,000}$ were thereby saved. The deficit was only $f_{4} \mathrm{I}, 346$, so that the normal revenue would meet all expenses. This was an excellent time to reduce the land tax, which had been the great aim of Walpole, but it then became necessary to provide for the $\mathfrak{f}_{500,000}$ that would be lost by the reduction of the $\operatorname{tax}$ to one shilling. The reduction was made, and Walpole raised the required sum by a loan on the salt tax, which had been revived. ${ }^{5}$ Walpole also foresaw, in the revival of this tax, a great source of raising revenue -a source which in future was to be used on more than one occasion.

The year 1733 is made famous by the Excise Scheme. On this, Walpole made the fight of his carcer. By its reform, he expected to realize his great ambition of keeping the land tax at one shilling, or if possible, of

${ }_{3}^{3}$ Geo. II, c. 14. $\quad{ }_{3}^{3}$ Gco. II, c. I6. $\quad{ }^{3} 3$ Gco. II, c. I.
${ }^{4} 4$ Geo. II, c. 9.


abolishing it. The deficit for the year'amounted to $\mathfrak{E I}_{160,000}$ and repairs to the navy cost $\mathfrak{E}_{104,000}$ more. Walpole thought that if he could tide over the year with the land tax at one shilling, the saving effected by the Excise Scheme would enable him to raise nearly the whole amount of the $£_{500,000}$ lost by the reduction of the land tax. The tax was levied at one shilling, and the sum of $£ 500,000$ was taken from the sinking fund.

In 1734 , the war scare in Europe caused a great increase in the army and navy expenses. The number of seamen was doubled and this fact added $£ 520,000$ to the current expenses. It was decided to discharge $\mathfrak{E I}_{\mathrm{I}, 2 \mathrm{CO} \text {,- }}$ ooo of the navy debt, the deficits were $£_{335}, \mathrm{cco}$, and incidental expenses $£_{90,000}$, so that for the year it was necessary to provide nearly $£_{2,250,000}$ of additional revenue. The excise scheme proved to be a failure, so that Walpole willingly restored the land tax to two shillings, but did not wish to arouse the landed interests by increasing it further. The fountain of wealth was the salt tax, which was continued, and used as a fund

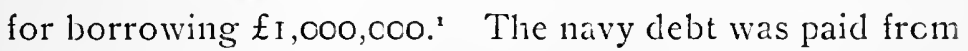
the sinking fund. ${ }^{2}$

To the act appropriating $£_{I}, 2 \mathrm{CO}, 0 \mathrm{CO}$ from the sinking fund was added a clause for a vote of credit. This gave the King power to raise any stim of money he thought necessary towards augmenting his forces by land and sea. ${ }^{3}$ The House, therefore, gave the King the general power of contracting debts without limit. This power could very easily be abused, and if the King had been very arbitrary, he cotild have contracted large debts. It was only used three times during Walpole's acministra-

${ }^{1} 7$ Geo. II, c. 6. ${ }^{2} 7$ Geo. II, c. 12 .

s Journals of the House of Commons, vol. xxii, p. 303. 
tion; in $1739, £ 500,000$ were raised to increase the navy, in $1740, \mathfrak{f}_{200,000}$ were borrowed for carrying on the war, and in $1741, \mathfrak{f}_{300,000}$ were secured for maintaining the Pragmatic Sanction. It was a dangerous power to place in the hands of the King, and if Walpole had not been thoroughly master of the position, he would hardly have dared to establish such a precedent. Mr. Hatsell in his Precedents of the Housc of Commons declares that this was contrary to the practice, which had been wisely established since the Revolution, of appropriating the supplies to the sources for which they had been voted. This power, during later years, was to be used to a great extent in raising money for the support of the army and the navy.

The year I 735 found Europe on the verge of war, and for its preparations England was compelled to expend a large sum of money. The extra appropriations to the navy amounted to $£ I, 040,000$ and the land force received

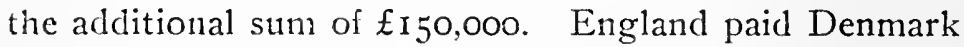
a subsidy of $\{56,250$. Extraordinary expenses were $E_{125}, 000$, and the deficit amounted to $E_{173,000}$. The total additional revenue was more than $\sum_{1}, 500,000$. The salt duty was continued, and formed a fund for raising $\left\{500,000 .{ }^{x}\right.$ In order to assure the support of the landed interest, the land tax was continued at the normal two shillings, and $\mathfrak{x}_{\mathrm{I}, 000,000}$ were taken from the sinking fund. ${ }^{2}$

The war scare having passed, the navy in $\mathbf{7} 736$ received an extra appropriation of only $£ 260,000$, and the army was restored to its peace footing of 17,704 men. The deficit was $£_{70}, 000$, Denmark was paid $£_{5} 6,250$, repairs to the navy cost $\mathfrak{E}_{3} 0,000$ and the extraordinary expenses 
amounted to $£ 83$, 000 . The extra revenue required was only $\mathfrak{x}_{500}, \mathrm{coo}$. The land tax was continued at two shillings, and $£ 600,000$ was borrowed on the sinking fund. ${ }^{x}$ The year 1737 found the navy restored to its normal strength. The plantations required an extra appropriation of $\mathfrak{f}_{50}$,000. The deficit was $\mathfrak{\Sigma}_{72}$, 000, extra expenses amounted to $\mathfrak{x}_{5} 6,000$, and repairs to the navy cost $\mathfrak{f}_{50}$,ooo. Denmark was paid $£_{42}, \mathrm{I} 87$, while other incidentals added $\mathfrak{3 0}$, 000 more, so that the extra revenue required was only little more than $£_{300,000}$. In raising this revenue, Walpole showed his shrewdness as a financier. The old duty of thirty-six shillings per barrel, on sweets, was abolished, and a new duty of twelve shillings was imposed. ${ }^{2}$ The old duty was appropriated to the South Sea Company, and the surplus was paid into the sinking fund, while the new duty was made a fund for borrowing $£ 500,000$.

The year 1738 saw estranged relations with Spain. The navy was strengthened by an extra appropriation of $\mathfrak{f}_{520} 20,000$. The deficit was $\mathfrak{f 6}_{60,000}$, and $\mathfrak{f}_{40}, 000$ were expended in building new ships. The plantations required an extra allowance of $£ 65,000$, and incidentals amounted to $\mathfrak{E}_{50,000}$. Walpole did not wish to increase the land tax, so that $£_{500,000}$ were appropriated from the sinking fund, and power was given to the King to borrow $\mathfrak{f}_{500,000}$ from the same source. ${ }^{3}$ The war cloud thickened, the navy expenditure in 1739 was increased by $£_{124}, 000$, the vote of credit was used to raise $\mathfrak{E}_{500,-}$ 000 , the deficiency was $\mathfrak{E}_{2} 3,000$, and the subsidy to Denmark $£_{70,583}$. The convention with Spain, and paying

' 9 Geo. II, c. 34 .

¿ 10 Geo. II, c. I7.

${ }^{3}$ I2 Geo. II, c. 19; the act appropriated another million from the sinking fund for public services, but it was enacted that this should be paid to the bank to redeem that amount of its capital. Cf. supra, p. 61. 
for Spanish depredations, cost $£ 60,000$. The plantations required an extra sum of $£ 70,000$, and the incidental expenses amounted to $\mathfrak{E}_{55}, 000$. The additional revenue

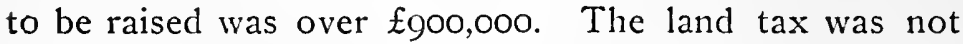
increased, but $£ \mathrm{I}, 000,000$ were taken from the sinking fund.

On the nineteenth of October, I739, the declaration of war against Spain was received with the wildest enthusiasm, and Parliament, amidst the greatest excitement, met on the fifteenth of November. The navy received an extra appropriation of $£ \mathrm{I}, 450,000$, and the land forces were granted an additional $\mathfrak{f}_{200,000}$. The plantations received an additional $£ 100,000$. The deficit was $£ 25,000$, and the subsidy to Denmark $£_{5} 8,333$. A vote of credit to aid in carrying on the war amounted to $£ 200,000$, and

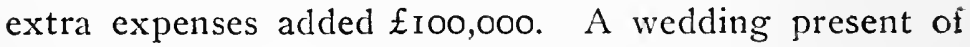
$£_{40,000}$ was given to Princess Mary. The additional revenue to be provided for was nearly $£ 2,200,000$. The country as a whole was so wrought up over the fabled stories of Spanish cruelties that the landed gentry received, without a murmur, a tax of an extra two shillings on land. This provided for $\hat{f}_{1,000,000}$ of the revenue needed. $\mathfrak{f}_{\mathrm{I}, 000,000}$ were voted directly from the sinking fund, and power was given to borrow $\mathfrak{f}_{200,000}$ more on the growing produce of that fund. ${ }^{\mathrm{x}}$

The following year more vigorous preparations were made for the war. The extra expenditure for the navy

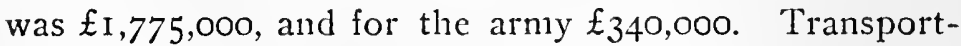
ing soldiers to America and providing for them required $£ 205.000$, the pay for Hessian and Danish soldiers was $£_{201}, 874$, and the subsidies to the two countries amounted

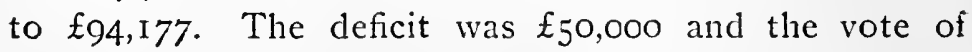


credit for supporting the Queen of Hungary in maintain-

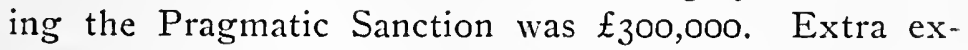
penses amounted to $£_{1} 55.000$. The increased revenue

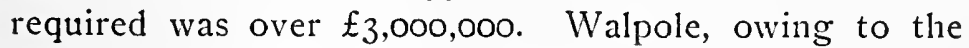
resentment against Spain, and the enthusiasm over the war, was able, without a murmur of discontent from the landed interests, to levy the land tax at four shillings. This added $£_{I, 000,000}$ to the revenue. The salt duty was continued, and furnished a fund for borrowing $\mathfrak{E}_{\mathbf{I}}$,200,000, ' and $£_{1,000,000}$ were appropriated from the sinking fund. ${ }^{2}$ Thus Walpole's financial ingenuity provided for this enormous sum, without any complaints from the people, and without increasing the burdens on the shoulders of the poor.

Walpole thus found England's finances in a very unsettled state, and left them on a sound footing. His coolness and deliberation in the treatment of the South Sea Company saved the country from an aggravation of the original crisis and a repetition of it. His careful restriction of the power of the directors of the company over a large portion of its stock took away the danger of another South Sea Bubble. The change in the payment of exchequer bills effected a great saving to the government. The diversion of the sinking fund for current expenses is criticized by many, but when we consider the England of that time, we must conclude that it was the wisest and most economical policy. The securing of revenue for extraordinary expenses discloses a master of finance, and one worthy in our opinion to be named with Pitt, Peel and Gladstone.

${ }^{1}{ }_{14}$ Geo. II, c. 22. ${ }^{2}$ I $_{4}$ Geo. II, c. 4 I. 


\section{CHAPTER III}

\section{ReFORM IN TAXATION}

THE English people have from the earliest times taken an active interest in problems of taxation. The struggle for English freedom is based thereon, and no privilege is as dear to the Englishman as the right of taxing. liven before our period, many prominent men had spent much time in the discussion and criticism of various kinds of taxes, in which we find a considerable development of economic principles, and occasionally traces of sound economic theory. During the twenty years of Walpole's administration, we have keen discussions in this field, and note a great progress in the discovery of economic principles. Walpole was the first statesman to take an interest in the theoretic consideration of the subject, and we accordingly find in his various tax reforms the leading principles of his economic policy.

Walpole on the death of his father came into an estate of about two thousand pounds a year. He knew and felt the hardships of the land-owners and his sympathies were with that body; consequently from the first, he opposed the land $\operatorname{tax}$, which he considered a burden upon the landed gentry. His aim was gradually to reduce the tax, until he should be able to bring about its abolition.

The land tax was established in 1692 , in order to raise money to carry on a war with France. ${ }^{x}$ At first, it

$$
{ }^{1} 4 \text { W. \& M., c. I. }
$$


included a tax on personalty, as well as on land. By 1697, the revenue from personalty had become almost a negligible quantity, so that the tax became a land tax only. The tax was granted annually, and the number of shillings in the pound of rental value varied. Local commissioners assessed the value of the property, and as a natural result of the infirmity of human nature under such conditions, the assessment was made much below the actual value. Thus even at first, there was an unfairness between the different counties and the different districts. With the great increase of wealth, varying in different parts of the country, the unfairness became more marked. On some the tax was slight, while on others it became a very heavy burden.

The tax from I 7 I 7 to I 72 I was levied at three shillings in the pound. In I 722 , Walpole reduced the rate to two shillings, and here it remained until 1727 , when owing to the threatened war with Spain, it was raised to four. The next year, the war cloud having somewhat cleared away, it was reduced to three and in I730 to two shillings. In 1732 , Walpole revived the duties on salt in order to levy the tax at one shilling, and the next year, to keep the tax at this rate, it was necessary to appropriate a half million pounds from the sinking fund. This same year, he introduced his famous Excise Scheme, hoping, by the change in the collecting of the duty on tobacco and wine, to increase the revenue, so that he would be able to continue the tax at the reduced rate. His scheme having failed, he was compelled, in 1734 , to raise the tax to two shillings, where it remained until I740, when it was increased to four.

All the land owners rejoiced at seeing the tax reduced to a shilling, yet the majority would have been very much opposed to its abolition. The tax, being levied on 
the assessment of 1692 , favored the land owners in the prosperous parts of the country. All these were very much against its abolition, knowing that in times of necessity it would be reimposed, and on an assessment that would not be so favorable to them. If Walpole had attempted to abolish the tax, he would have met with a strong opposition from the land owners themselves.

During the first half of the eighteenth century, there was a great development in agriculture as well as in trade and manufactures. England was a great exporting nation, and helped to feed many of the continental countries. Bountiful harvests and few bad crops poured wealth into the pockets of the land owners. The period also marks the beginning of capitalistic farming. Land seemed to have been a badge of aristocracy, and the rich traders and merchants were anxious to become land owners and farmers. So great was the interest taken in agriculture, that Rogers exclaims: "It seemed to be the reigning taste of the age."

The latter part of the seventeenth century marks the beginning of the accumulation of great fortunes by the merchant classes. The stigma which was supposed. to cling to the trader was gradually being removed. Temple, writing near the close, remarks: "I think I remember the first noble family that married into the city for downright money." The merchant princes began to be looked upon as a new class, and worthy of a social standing. Defoe discovered that men engaged in business might be refined, and Johnson was forced to admit that an English merchant was a new species of gentleman. This new class began to assert great influence. They were Whigs and not loved by the Tories. Dean Swift, in speaking of them, saic that the power which used to follow land had gone over to money. The 
old landed gentry did not have any more love for this new addition to their ranks than they did for the Hanoverian king. A western squire, storming at the accursed Hanoverian dynasty whenever his sister began to talk politics, is a true representative of the good old English gentleman. With consternation did he look upon the wealthy traders and merchants buying estates. It took time and statesmanship to make the old squire look with favor on the Hanoverian family. The new additions to their ranks, of staunch followers of King George, had a great influence in lessening the antagonism.

To win over these squires was one of the chief reasons for Walpole's opposition to the land tax. He thought by reaching their pockets to lessen their hatred and to gain their loyalty for the Hanoverian dynasty, which he above all things wished to sec firmly established on the English throne. The great prosperity enjoyed by England and the low rate of the tax won the English squire to the new state of affairs. This was seen in his refusal to answer the call to arms in favor of the young Pretender in I745. Thus Walpole succeeded in making England a united country and the rule of the Hanoverians secure. His other chief purpose was to keep in office. Since the landed interests had the control of the two Houses of Parliament, Walpole was forced to depend upon them for office. He had already allied himself with the wealthy merchants and tradesmen, who by buying rotten boroughs and landed estates had commenced to be a formidable body. Yet as they did not control the House of Commons, he had to have the support of the land-owners. The land tax was considered a grievance, and by lessening it he was certain to win the favor of the landed gentry. Thus the two political reasons for Walpole's opposition to the land tax were his desire to win over the English squires and his desire to keep in office. 
In order to learn the economic principles that guided Walpole in his policy, we must first study his theory of taxation. If we go to his speeches and pamphlets we find this clearly and definitely stated. He recognizes taxes as "necessary to the very being of all government," $x$ and as such not in themselves grievances. Granted then that taxes are essential, the question arises as to how they are to be raised. He is quite right in answering that the chief care of legislation ought to consist in imposing such taxes as might be borne most easily by the whole body of the people. ${ }^{2}$ What are these taxes, we may ask? Thousands of pamphlets and books have been written to answer this question. Hundreds of financiers and theorists have for a time rejoiced in the thought that they had found a solution, only to be sorely disappointed when their theories would not stand criticism and the test of practice.

Walpole in answer says: "When money is to be raised for the public good, for the security of all, one ought to contribute his share in proportion to the benefit that he is to receive." 3 Are we to make any distinction between the rich man and the poor laborer? He answered that when the benefit is mutual, the expense ought to be common. ${ }^{4}$ Therefore every one ought to pay something, the poor man his mite, the lord his sovereign. He sums up his view as follows: "As to the manner of raising taxes upon the people, it is a certain maxim that that tax which is the most equal and the most general is the most just and least burdensome." ${ }_{5}$ Thus we have the basis of his great belief in the excise. Walpole did not contribute

'Walpole, R., Letter Concerning Duties on Winc and Tobacco, p. ro.

${ }^{2}$ Ibid.

Ibid., p. 944 .
${ }^{3}$ Hansard, op. cit, vol. viii, p. 943.

'Ibid. 
anything new to the theory, as it is found in the recital to an ordinance dated August the fourteenth, I649, which describes the excise as "the most equal and indifferent levy that could be levied on the people." " Petty in his Treatise on Taxes reaches the same conclusion. ${ }^{3}$ Thus in his theory of taxation Walpole simply accepted that which had been the established belief for more than half a century.

Following his maxim, he was consistent in opposing the land tax, because it was specific and not general. This is the economic basis of his opposition, as is seen from his criticism of the tax as "a burden so long and so grievously borne by a small proportion of the whole collective body of the nation." 3 In one place he describes the tax "as the most grievous and most unequal of all our taxes," ${ }^{4}$ and in another he asserts that there was no tax "that ever was laid upon the people of this nation that is more unjust and unequal than the land tax." 5 He concludes that the tax should be levied "only in times of the most extreme necessity." 6 The reasons for his opposition to the tax were, therefore, economic as well as political.

Walpole shared the accepted belief of his time, that the land tax could not be shifted, and therefore rested on the land-owners. In one place, as we have just seen, he speaks of the tax "as a burclen so long and so grievously borne by a small proportion of the whole collective body of the nation," " and in another he says, "it has

'Scobell, Statutes, London, 1658.

2 Petty, Taxes, London, 1689, p. 72.

${ }^{9}$ Walpole, Letter Concerning Duties on Wine and Tobacco, p. II.
"Ibid.
${ }^{3}$ Hansard, op. cit., p. 944.
'Ibid., p. gt8.

'Walpole, op. cit., p. II. 
continued so long, and has lain so heavy, that I may venture to say, that many a landed gentleman of this kingdom has thereby been utterly ruined and undone." ${ }^{2}$ No doubt can exist from this quotation as to his belief that the tax could not be shifted from the landowner; but in the following quotation one cannot say so definitely that Walpole was consistent in his views, unless he was impelled by other circumstances to make the statement: "To the people it is of infinite advantage, since it tends to lessen, and perhaps to abolish, the land tax: a tax which falls heavily upon them by heightening the rents of land, and consequently of bread and drink and other food, so that what the land pays, the people too pay." = Here it is stated that the tax is shifted to the tenant, and by him to the consumer. We can answer this inconsistency by saying that it was simply a political expediency. In the other cases he was pleading with the landowners; in this pamphlet he was addressing the people: it was necessary to make his arguments suit the case. We can, however, not doubt but that he fully understood that the tax could not be shifted from the landowners.

The confusion and disaffection which followed the South Sea scheme were favorable to the views of the Jacobites. The leading Stuarts, with Bishop Atterbury at their head, planned a general revolt. The plot was discovered and great excitement followed. Amidst great confusion the new Parliament met on the ninth of October, I722. The first act of the House was to suspend the Habcas Corpus Act for one year. A few days later, Walpole took advantage of the resentment against the Papists, and introduced a bill for raising $\mathfrak{E}_{\mathrm{I} 00,000}$ on the

\footnotetext{
'Hansard, op. cit.. p. 944.

-Walpole, General Considerations of Pablic levenues, p. 9.
} 
estates of Roman Catholics.' On a subsequent motion, the tax was extended to all non-jurors. This clearly shows his intense hatred toward the Roman Catholics, so characteristic of the man, and explains the reason for his being so much opposed to Stanhope's project for relieving them from penal laws. Walpole justified the tax by claiming that the Papists should reimburse the nation for part of the expense occasioned by the revolt. His ain was to use this as a means of checking the plots of the Roman Catholics against the government. The justification of the policy, however, is in doubt. Coxe claims it to be "according to the strict rules of theoretical justice," while Onslow declares "his abhorrence to punishing men for their religious opinions." The modern world will side with the latter, for although it checked the growth of disaffection, we of to-day cannot see any justice in punishing men for their religious beliefs.

After the Restoration, the revenue of the King was

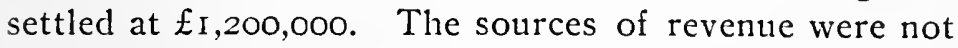
sufficient, so Parliament in 1662 granted His Majesty a house tax of two shillings on every hearth. ${ }^{2}$ The tax in 1668 produced $£ 200,000$ a year, but was an object of intense hatred. Numerous petitions against it were received by William before he reached London, and after an investigation he consented to its repeal. But the urgent need of money caused Montague, in 1695 , to reimpose a tax on houses. ${ }^{3}$ At first, it was to be levied

' The tax was to be assessed on all Papists of eighteen years of age, over and above the land tax. If the full sum charged was duly paid, it discharged the Papists' estates from two-thirds of the rents thereof for one year, and from all penalties for recusancy. Pickering, Statutes at Large, vol. xv, p. 73. 9 Geo. I, c. I8. The tax produced $£ 96,000$.

'I 3 and 14 Chas. II, c. 10; Revenue, I662, $£$ I70,c00 per annum.

${ }^{3} 7$ and $8 \mathrm{Wm}$. III, c. 18 . This was a fixed rate of $2 \mathrm{~s}$. per annum 
for a period of seven years, but was continued in 1697 to $1706,{ }^{\prime}$ and in that year made perpetual. ${ }^{2}$ An add. tional tax on large houses was levied in $1709 .{ }^{3}$ The tax was in operation throughout Walpole's administration; although opposed to the tax, he did not make any attempt to alter it. "The best judges, the truest patriots in all countries have been of opinion that of all taxes that on immovable goods, that upon lands and houses ought to be the last resource." 4 In another place he speaks of "the proportions of the land tax and the window tax, by which one estate is loaded in favor of another." 5 The tax did not evoke much attention until I743, when Decker came forth with his scheme of a single tax on houses." 6

Excises are defined by Walpole as "duties payable by the retail merchant upon consumption." Such a tax was held by him to be one on expencliture, and this, he thought, was the ideal method of taxation. In sharing this belief, he simply followed that which had been accepted for more than half a century. Prior to I732, there were a few opponents to the old theory, but it was the revival of the salt tax that gave rise to the heated conversy. In the numerous pamphlets that were pub-

on every dwelling house inhabited. Houses with ten windows were to pay $4 \mathrm{~s}$. per annum, and houses with twenty windows 8 s. per annum above the $2 \mathrm{~s}$.

${ }^{1} 8$ and $9 \mathrm{Wm}$. III, c. 20. ${ }^{2} 5$ Anne, c. I3.

58 Anne, c. 4 ; the additional taxes were, that every dwelling house inhabited, having over twenty and under thirty windows Ios., and thisty windows or more 20 s.

${ }^{4}$ Hansard, op. cit., p. 968.

${ }^{5}$ Walpole, Letter Concerning Dutics on Wine and Tobacco, p. 31 .

'Matthew Decker, Serious Considerations . . Raising all the Public Supplies by one Single Tax, 1743 . 
lished, we find the excise system fiercely attacked, and - any of its fallacies set forth.

"At the commencement of the Civil War, the Roundheads found it difficult to raise money. William Pym, a shrewd politician and financier, suggested that a new tax called excise, which for years had been levied with success in Holland, should be introduced. A resolution based thereon was brought in, on March the twentyeighth, I643, and carried into effect by an ordinance of the same date. An cxcise was granted on beer, wine and a few other commodities. During the year many more were added, and additions were made from time to time, until at the close of the Commonwealth hardly a commodity escaped. Among the few that were exempted, we find salt used in curing fish, imported bullion, corli, arms and ammunition. The tax, at first, was granted annually, later for a term of years, and finally in many cases, in perpetuity.

At the Restoration, the raising of taxes by excises was organized under the hereditary and temporary excises as a permanent system of revenue. The hereditary was granted in perpetuity, and the temporary during the life of the sovereign. The one was a duplicate of the other. The number of commodities was reduced to a small list consisting of beer, spirits, cicler, mead, vinegar, tea, coffee and chocolate. It had been discovered not only that the excise on tea, coffee and chocolate was very burdensome, but that owing to the great expense in collecting, it produced very little revenue. In the granting of the temporary excise to William and Mary, the excise on the afore-named articles was abolished, and in lieu thereof, special import duties were imposed upon tea in the leaf, coffee berries, cocoanuts and chocolate. At this time, the importation of these articles was not very ex- 
tensive, and would not have produced a very large revenue, even if all the duties were paid. By the beginning of the century, the consumption had greatly increased, and the excessive duties made smuggling very profitable. The system of smuggling once started increased with such rapidity that, by the time of Walpole, the amount of duty lost on certain articles, was more than that collected. From time to time, acts were passed imposing new excises, until in $\mathrm{I} 72 \mathrm{I}$, we find a large number of commodities subject to a tax.

Soon after Walpole's appointment to the head of the treasury, his attention was turned to the improving of the public revenues. He knew that the amount received by the treasury should be far more than it was, and that thousands of pounds which should have been paid into the public purse made wealthy men out of an army of smugglers. Owing to the excessive duties on tea, wine, tobacco and coffee, and the great demand for these commodities, smuggling had become very profitable, and had grown into a very extensive system. It became Walpole's aim to turn the money that had previously gone into the pockets of the smuggler into the coffers of the government. This could be done either by decreasing the duty, thereby making smuggling unprofitable and increasing the revenue by the augmented demand for the commodities, or by changing the method of collecting the tax, making it more rigid and lessening the opportunity to smuggle. At this time the reduction of an excessive duty was an experiment, and he preferred the second plan. In the warehouse system of collecting the excise he saw a solution for his problem. By a change in the case of a few commodities, he anticipated a sufficient increase in revenue to cnable him to carry out his great purpose, the reduction of the land tax. 
There is no doubt that he had already planned the changing of import duties on many commodities into inland duties, or in other words, the making of them subject to the excise law. Too great a change could not be brought about at once, so that it was necessary to experiment with two or three commodities. He well understood the intense hatred that the people had for the very term excise, and in his experiment he very wisely used the term inland duties.

Tea, coffee and wine, three commodities that were in great demand, were subject to excessive duties, and were smuggled into the country on an extensive scale. Walpole well knew the power of the merchants who were amassing fortunes out of their clandestine trade, and did not wish the opposition that a change in all three would provoke. Owing to the fact that tea was a universal article of consumption, subject to a very high duty, ${ }^{3}$ and could be easily smuggled, he chose this as the chief commodity for experiment. He joined with it coffee, cocoanuts and chocolate, articles of lesser importance, duties which could be changed without evoking much opposition. In I 724, Walpole's plan was put in force. By an act of that year, certain duties payable on tea, coffee and cocoanuts $^{2}$ were abolished from June the twenty-fourth,

'Different duties on tea, 1724:
A. Five per ceilt. subsidies on the value $1660-1698$.
B. One-third subsidy of Queen Anne.
C. Two-thirds subsidy of Queen Anne.
D. Additional imposts.
E. Special taxes:

I. One shilling a pound 1695.6 and $7 \mathrm{Wm}$. III, 7 .

2. One shilling a pound 1704. 3 Anne, c. 4 .

3. Two shillings a pound 1712 . Io Anne, c. 26.

Dowell, Taxation, vol. ii, p. 94.

${ }^{2}$ Duties payable on tea and coffee that were aboished were thost 
and in lieu thereof the following inland duties were imposed: on coffee, two shillings, on tea, four shillings, and on chocolate made or sold, one and one half shillings per pound, over and above all duties payable by other acts upon the importation thereof. The importation of chocolate ready made, or cocoa paste, was prohibited. The new duties were to be collected by commissioners appointed by the King or the Treasury ${ }^{2}$ and the powers in the excise acts were to be exercised for the execution of this act. A very important change was made in the section that required the compulsory warehousing of tea, coffee, and cocoanuts. Warehouses were to be established in which these articles, on importation, were to be deposited after paying certain duties, ${ }^{2}$ and from which they might be taken for exportation without any further payment. The inland duties or excises were chargeable only upon the commodities which were sold for home consumption. This system of compulsory warehouses was one of the most important reforms effected by Walpole and one which, if more widely adopted, would have greatly aided English trade and commerce. The change took place without the slightest opposition. The bill passed the House of Commons and the House of Lords without any murmur of dissent. The wealthy merchants did not have any means of stirring up the ignorant people, and accordingly resigned themselves to their fate. In a short time it not only increased the revenue by $£$ I20,000 a year, but materially aided the export trade in tea and coffee.

passed A. 6 and 7 Wm. III, c. 7; B. 3 Anne, c. 4; C. 1o Anne, c. 26. The duties abolished on cocoanuts were those established by A. 6 and 7 Wm. III, c. 7 ; B. 3 Anne, c. 4.

${ }^{1}$ io Geo. I, c. 10.

*The several subsidies and the additional impost. 
The excise on malt was a favorite means for raising revenue. Like the land-tax it was granted annually by Parliament. The tax was first imposed in $1697,,^{1}$ by an act which also provided for excises on mum, sweets, cider and perry. ${ }^{2}$ The importation of malt was prohibited, and the excise was repaid upon exportation. The first change in the tax was in the malt act of $1725,{ }^{3}$ when the usual malt tax was continued for another year in England, and was now for the first time extended to Scotland. The malt of Scotland was not considered as good as that of England, and so the duty was levied at three pence per bushel; but in case it was sent to England the duty was raised to six pence. The duty upon mum, cider and perry was made the same as in England. A slight change was introduced in 1726 , in that malt made for exportation should pay no duty nor have any drawback. ${ }^{4}$ The last change is found in the act continuing the duties for the service of the year I730, whereby cider and perry used in Scotland for distilling were exempt. ${ }^{5}$ The tax was a popular one, because since it was levied every year many believed it to be one of the checks that Parliament had on the crown.

The tax was a security for a loan, and the money was usually raised by means of exchequer bills. ${ }^{6}$ The rate of interest depended on the credit of the country and the ratio between the amount of loans sought and the supply of money seeking investment. For the service of the

18 and $9 \mathrm{Wm}$. III, c. 22 ; the malt tax was six pence per bushel.

${ }^{2}$ Mum, ten shillings a barrel; sweets, twelve shillings a barrel; cider and perry, four shillings a hogshead; these were over and above all former duties.

${ }^{3}$ I I Geo. I, c. 8. 412 Geo. I, c. 4 .

${ }^{5} 3$ Geo. II, c. 7.

Exceptions were made in the years 1723,1724 and 1725 , when the money was raised by lottery. 
year 1722 , the borrowing of $£ 700,000$ on the tax was authorized, ${ }^{x}$ but owing to the precarious state of public credit, caused by the South Sea Bubble and the Jacobite agitation, the government was compelled to pay five per cent. During the ensuing three years it was necessary to raise the loan on the tax by lottery." In 1726 , full confidence in the public credit having been restored, the government was able to obtain the loan for three per cent., and with the exceptions of the years 1734, I735 and 1739 , when it was raised to three and a half, it remained at that rate to the end of Walpole's administration.

Walpole did not appear to be in any haste to extend the excise system. After the success of the experiment with tea and coffee, one would naturally expect that he would make other changes. He was, however, a politician and consequently careful about doing anything that might cause too much of an opposition. He was much opposed to any innovation, and followed very closely his motto: "Quieta non movere." Before we come to the controversy over the salt excise, we must note one slight addition to the list of excise articles. In I 729, an act was passed imposing a duty of five shillings per gallon on all compound-spirits made after Christmas of that year. ${ }^{3}$ The tax was granted for five years and on its expiration was not renewed.

The excise on salt had from the first been the cause of much complaint. The poor murmured at the burden placed upon their shoulders, while the wealthy complained of the method of collection. The excise had

18 Geo. I, c. I.

"From 1725 the amount authorized to be borrowed was $\measuredangle 750,000$.

$s_{2}$ Geo. II, c. 17 . 
been put under a special commission, and large salaries were allowed the commissioners. Serious charges of corruption were made against them, as well as against the collectors. Thus the abolition of the tax met with approval of both the rich and the poor. The salt act of $1730^{\mathrm{x}}$ enacted that the excise of three half-penny per gallon, on home-made or rock salt, imposed in $1693^{2}$ for three years, and made perpetual in $1696 ;{ }^{3}$ also the additional excise of three half-penny per gallon on homemade or rock salt, passed in $1698 ; 4$ and finally the duty of seven pence per gallon on imported salt, also granted by the same act, ${ }^{5}$ should all be abolished from and after Christmas I730, but that the several other duties on imported salt should still remain.

The question arises as to why Walpole abolished the salt excise, since in a short time he was praising its qualities as an ideal tax. From this, we infer that his policy was not prompted by his economic principles. There is not the least doubt that he had been working out a scheme for the extension of the excise. This would naturally follow since his experiment worked so well, and excise was his favorite method of taxation. Walpole, being a man opposed to criticism, would prefer to leave things as they were, rather than to introduce innovations that would stir up undue opposition. He would not bring forth any plan of reform until the time was ripe for its acceptance. It is clear that he relied on the landed interest to carry his excise scheme. He was aware that he could not, this time, deceive the people by the use of terms, but had to come out frankly with the word excise.

' 3 Geo. II, c. 20.

s 7 and $8 \mathrm{Wm}$. III, c. 3 I.

${ }^{3} 5$ W. and M., c. 7 .

4 and $10 \mathrm{Wm}$. III, c. 44 .

${ }^{b}$ This duty was under the management of the commissioners of excise. 
The one excise that caused more objection than all the rest was the salt tax. If he would remove this, the people would be more favorable to his proposed scheme. This was therefore merely a step in paving the way for the acceptance of his excise scheme.

In I732 Walpole became alarmed over the increasing opposition among the landed gentry who were too much concerned in the vindictive attacks of Pulteney. $\mathrm{He}$ had a sufficient following to insure a good majority, but in order to lessen the opposition, he wished to win over the landowners who were wavering. He was not ready to bring forth his excise scheme, and something had to be done to keep the landed party in line. He proposed to accomplish this by reducing the land tax to one shilling, which, however, would not be sufficient to meet the expenditures. Consequently, if the tax were to be reduced, the amount lost must be made up by other means. Since he was opposed to any innovation, he did not favor the introduction of a new tax. The people were accustomed to the salt tax, and he thought that its re-establishment would not cause as much opposition as new imposts, and would furnish the half million lost from the revenue. The land tax was consequently reduced to one shilling,' and the excise on salt was reimposed. ${ }^{2}$ In order partly to check the criticism that would necessarily arise, he limited the time of imposition to three years, trusting that the change would be received with such approval by the landed interests that their overwhelming majority would tend to stamp out any opposition that might arise. In this Walpole was partly right and partly wrong. It was received with the greatest approval by the landed interests, as is seen in the very large majorities

's Geo. II, c. 5 .

${ }^{2} 5$ Geo. II, c. 6. 
by which they voted down 'every ${ }^{i}$ mocionr 'ic' "arisnd. Although the vote showed in itself a great triumph, the revival of the tax nevertheless sounded the knell of Walpole's ministry.

His arguments in behalf of the salt tax were that when money was to be raised for the security of all, every one ought to contribute his share in proportion to the benefit that he was thereby to receive; the tax which was the most equal and the most general was the most just and the least burdensome; where every man contributed a small share, a great sum might be raised for the public service without any one being sensible of what he paid; where the benefit was mutual, the expense ought to be in common; of all taxes there was not one more general or less felt than that of the duty on salt; the salt tax would fall equally on all, and would be burdensome to none; the duty on salt was a tax that every man in the nation contributed according to his circumstances and condition in life; there was no tax that ever waslaid upon the people of the nation that was more unjust and unequal than the land $\operatorname{tax} ;{ }^{2}$ his sole purpose was to procure some relief to the landed interests. ${ }^{3}$ This is the first time that we find Walpole giving expression to open support of taxes on expenditure. It was immediately taken up by the opposition, and he was charged with reviving that terrible burden, the excise, and anticipating that devouring monster, the general excise. It was an opportunity for which Pulteney and his followers had been waiting. Thus began the fiery controversy which, in the light of economic theory, was to prove very fruitful.

Walpole's motion gave rise to many pamphlets and aroused an animated discussion in the Houses. The chief

$$
\text { 'Hansard, op. cit., p. } 943 . \quad \text { 'Ibid., p. 944. 'Mbid., p. } 945 .
$$


argurierts brought forth 'by the opposition were as follows: that the land tax was not the only tax which had lain heavily upon the landowners, but every other tax fell at last upon them with the greatest weight; there was no gain to take off one tax that lay heavily upon the landed interests and in its place to levy another that would rest equally as heavily upon the most of them; it was not always true that the taxes that were the most general were the least burdensome, but in all countries it was true that the taxes laid upon the luxuries of mankind were the least burdensome; ${ }^{1}$ the laborers received a bare subsistence, and therefore did not bear a tax, so that if you tax a necessary article of life, you levy a tax on the manufacturer, because he has to raise wages or the laborers will starve; ${ }^{2}$ a duty laid on a produce, either foreign or domestic, would raise the price to the consumer more in proportion than what the duty amounted to ${ }^{3}$ the salt tax was a very unjust and unequal tax, because the most wretched were the most heavily taxed, and the more a man had, the less he was obliged to pay toward the general public expense; ${ }^{4}$ the salt tax was only a step toward the general excise; ${ }^{5}$ every man ought to pay to the public charge in proportion to the benefit he received therefrom; a poor man, who had no property, ought certainly not to be charged for the defence of property, since he had nothing but his liberty to contend for; liberty might be equally dear to every man, but surely he that had the largest property

'Hansard, op. cit., p. 946, speech of W. Plummer.

Ibid., p. 1051, speech of Lord Bathurst, House of Lords.

'Ibid., p. 1042, speech of Lord Carteret, House of Lords.

'Ibid., speech of Lord Carteret, House of Lords.

'Ibid., p. 972, speech of Wm. Pulteney. 
ought to contribute most to the public expense." Walpole, in answer, declared that he never had thought of introducing a general excise, and said that the laying of an excise upon one commodity, or upon one sort of provisions, could no more be a precedent for a general excise than giving a poor man half a crown could be a precedent for giving him a whole estate. ${ }^{2}$ In this we can not but believe that he was sincere. For Walpole was a man so opposed to innovation that even though he believed that the excise system was the most equitable way of raising revenue, he would have shrunk from attempting to introduce so radical a reform.

We may next inquire what different theories of taxation were advanced in the controversy? In the first place Walpole and his followers upheld the accepted theory of general excise. This can be no better stated than in his own maxim, that that tax which is the most equal and the most general is the most just and the least burdensome. In the opposition, many theories were expounded. In opening the attack, Mr. Plummer took exception to Walpole's maxim and held that taxes should be limited to those on luxuries of life, and that care should be observed to exempt those articles necessary for the sustenance of the poor laborer. ${ }^{3}$ Sir William Wyndham in a following speech advanced the doctrine that the amount of property which a man possessed, rather than his expenditure for consumable commodities, should be taken as a standard of his ability to pay for the support of the government. ${ }^{4}$ Lord Carteret, in the House of Lords, objected to the salt excise, in that the rich man

'Hansard, op. cit., p. 953, speech of Sir Wm. Wyndham.

"Ibid., p. 960, speech of Walpole.

'Ibid., p. 946, speech of Wm. Plummer. 'Ibid., p. 953. 
did not pay proportionately as much as the poor man, or as he puts it "the most wretched are the most heavily taxed, and the more a man has, the less is he obliged to pay toward the public expense." "He had in mind that ability to pay should be measured by property, not consumption. Lord Ilay upheld the income tax as the most equitable. He said that if the government could make every man contribute to the public annual charge, according to the rents or profits he had yearly coming in from his estates, or from his trade in business, this would be the most equitable way of levying taxes." The controversy thus disclosed four different methods of deciding the test of ability to pay taxes. Some thought every one should pay something, thus justifying a tax on necessaries; some believed the poor should be exempted, with a proposition to tax luxuries; some maintained that property and not consumption should be the test; and some contended that income should be the criterion to follow. The fierce controversy thus shattered the old belief in the general excise and was instrumental in bringing forth new theories.

The discussions were equally productive of different theories of incidence of the excise. Walpole, in the first place, declared that the tax was paid not by the maker or the seller, but by the consumer, ${ }^{3}$ and that the poor man paid such a trifle on the amount he consumed that it was not a burden on him. Many of the opposition agreed with him as to the incidence, but differed in the contention that it was a heavy burden on the poor laborer. Secondly, Mr. Plummer maintained that all taxes were for the most part shifted to land, and that

Hansard, op. cit., p. 1042, speech of Lord Carteret.
'Ibid., p. 1055.
${ }^{3}$ Ibid., p. 944. 
the landed interests as a body did not gain by the change. ${ }^{x}$ While, thirdly, in the House of Lords, Lord Bathurst insisted that as the laborers received a bare subsistence wage, they could not bear the tax, and that it was shifted to the employer of labor. ${ }^{x}$ It was therefore disadvantageous to the manufacturer competing in the foreign market, and his interests, as well as those of the trader, suffered. In passing, it may be well to note that Lord Carteret contended that the excise, in being shifted, increased the price of the commodity more than the amount of the tax. ${ }^{3}$ We have, therefore, three distinct theories as to the incidence of the tax. Some contended that it was shifted to the consumer, some maintained that it was shifted to the landowner, and some insisted that it was shifted to the employer of labor. The theory that it was shifted to the consumer, and became an extra burden on the laborer, was the one that received the greatest support.

The opposition seized every opportunity to increase their power against the government. People were made to believe that excise was some monster that would take the bread from their mouths and leave them to starve. Pamphlets and placards without number were used to arouse the common people. Scores of speakers addressed meetings in every part of England. The real meaning of excise was not explained, for the term served the purpose better. Among the landowners, we notice a change of belief regarding the tax. The theory that all taxes eventually fell on them won many to the side of the opposition. The contention that the excise was an

'After this discussion Pulteney, D'Anvers, and others published pamphlets upholding this view.

${ }^{2}$ Hansard, op. cit., p. I05I.

"Ibid., p. 1042 . 
unjust burden on the poor laborer was gaining many adherents and by the beginning of 1733 , there was a great opposition among the common people, and even among the landed gentry. This was partly the result of ignorance, and partly the result of the breaking down of the old theories of incidence and the acceptance of the newer doctrine.

Walpole, in his speech in support of the salt tax, said that if the tax were carried, some means might be devised for lessening the burden of the landowners for the ensuing year. From this insinuation, many believed that the revival of the salt excise, was only a step toward other changes. This explains the activity of the opposition in arousing the people against the excise. In providing the revenue for 1733 , it was fully expected by the House and the public that in order to continue the land tax at one shilling, some excise plan would be brought forth. At the opening of Parliament, the land tax was granted at one shilling, and all the members of the opposition were disappointed when Walpole carried his motion to make up the loss of revenue by taking $f_{500,000}$ from the sinking fund. This disappointment is seen from a speech of Mr. Rushout, who said that he imagined there was a certain scheme to be introduced which seemed to be of great importance to the country. The House had waited long for this glorious scheme which was to render them all completely happy. They had imagined that it was to come in lieu of the one shilling in the pound land tax. The measure had, it seens, been altered and they had seen the ease to the land tax already supplied. He did not know if the scheme had been amended or altered, but trusted that if such a schene were to be introduced, it would be brought in at the beginning of the session before the majority of 
the members had returned home. ${ }^{2}$ The House had for a year been conjecturing as to the nature of the plan. They expected a somewhat radical reform, based on converting certain duties into excises. The opposition, with their increased strength, were ready to condemn and censure at sight any scheme in which the term excise might be used. Walpole, in his reply to Mr. Rushout. admitted that he had a scheme which he intended scon to lay before the House, and further said that he lad resolved to make a motion two weeks hence for the House to go into Committee of the Whole on the frands committed in the collection of the public revenue. He would lay before this committee a plan which, he was convinced, was for the good of the nation and the public revenue. His proposition had been carefully thought out, and he was willing to receive any suggestion as to its improvement. His sole aim was to check smuggling. and to turn into the treasury the revenue that was enriching a large army of smugglers. ${ }^{2}$ Walpole was careful to place particular stress on the prevention of fraud, realizing that the term excise had, as far as possible, to be kept in the background. By emphasizing the gain to the nation, by the prevention of all kinds of fraud in the collection of public revenue, he thought he would overcome that part of the prejudice that had arisen against excises.

The opposition waited in patience for the presentation of the scheme. Amidst great excitement the House opened on the morning of March the fourteenth, 1733 . Immediately on assembling the House resolved itself into a Committee of the Whole to consider the most proper methods for better securing the revenue on 
tobacco and wine. Many accounts and papers that had been ordered on the previous day were referred to this committee. The Commissioners of Customs and Excises, pursuant to orders, were in attendance to furnish any desired information from their respective departments. Everything was in readiness for the reception of Walpole's scheme.

In behalf of his scheme, Walpole opened the debate, and said that the purpose was the better securing of duties on tobacco. The only way to accomplish this would be by the prevention of frauds, and his proposed sclieme would effect this by an alteration in the method of collecting and managing the duties already imposed. The coming contest would be between the fair trader, the public and Parliament, on the one hand, and the unfair trader on the other. Those who profited by the present system would, he thought, stir up the people to mutiny and sedition. Yet, as the scheme would increase the revenue by two or three hundred thousand pounds he would not be deterred by calumny or clamor. In all plans for the benefit of government two points had to be considered-justice and practicability. Many things were just which would not be practicable, but a general excise scheme would be neither the one nor the other. He most unequivocally asserted that no such scheme had come into his head, or, as far as he knew, into the head of any man with whom he was acquainted.

It was the grievance of the merchants and his own investigation that induced him to seek a remedy. If he failed, he promised that this should be the last attempt he would ever make. For some time the American colonies had complained of the frauls on the part of their English agents. Remonstrance after remonstrance had been sent to the mother country, setting forth their 
grievances and praying for relief. His scheme was to remedy all these, and to secure fair dealing for the American planter.

There were several methods of fraud practiccl in robbing the government of its due revcnue. First, false quantities were entered in the columns of merchants' books on importation, and by collusion with the officers, slips of paper, upon which were written the real quantities which were entered, were skillfully pasted over the false figures. This was done because it was neccssary to produce the same book when the tobacco was entered for exportation. Secondly, drawbacks were received for tobacco on exportation and it was re-landed. Thirdly, the whole drawback was often given for a commodity of almost no value. It was customary to cut out and press the stalks of the tobacco; this was then mixed with dirt and sand, and the same drawback was obtained as for the true plant. Fourthly, great quantities of tobacco were stolen from ships anchored in the river. These four devices were the means of defrauding the government out of a large sum of money annually. Walpole held that there should be a way of checking these frauds, and thereby materially increasing the revenue of the country. The only remedy, it seemed to him, was to change the method of collecting these duties. To the laws of customs he proposed to add the laws of excise, and he trusted that by means of the two the frauds would cease.

The several imposts on tobacco amounted to six and one-third pence per pound, all of which had to be paid on importation, either in cash, with an allowance of ten per cent., or in bonds with sufficient securities for payment. By Walpole's scheme the whole duty amounted to no more than four pence and three farthings per pound. All tobacco on being imported was to be 
weighed at the custom-house, and charged with three farthings, ${ }^{1}$ whereupon it should be stored in warehouses to be appointed by the commissioners of excise for that purpose. The tobacco should remain there until a market was found; if the market were for exportation it could be exported, and the merchant would receive back the three farthings he had paid; but if the market were for home consumption he was to pay the additional fourpence per pound, and then he could deliver it to the buyer. ${ }^{2}$ This was the famous excise scheme which Tucker praised so highly, and which, if put in force, would undoubtedly have been a great boon to trade.

The main point which alone could admit of debate, $W$ alpole contended, was subjecting the dealers in tobacco to the laws of excise. To this change several objections would be raised. Firstly, the tobacco merchants declared that it would subject them to slavery, but Walpole pointed out that brewers and maltsters had been for years under the same laws, and were not slaves. Secondly, it was charged that the crown would gain, but this would not follow because the increase in inland luty would not go to the crown but to the public, and the subsidy of three farthings, which went to the civil list, would be paid at the custom-house. All fines, forteitures, and penalties, arising from inland duties, were renounced by the crown, and appropriated to the public. The crown would have no interest in inland duties, but as trustee for the public. Thirdly, it was objected that the merchants would be subject without appeal to the decision of the commissioners. For this a remedy was supplied by investing three of the twelve judges in

: This tax was a further subsidy.

"Hansard, op. cit., pp. 1268-1281. 
the city of London with a power to determine, in a summary manner, all appeals brought before them, and by giving the same power in the country to one of the judges of the assize. This rendered impossible the sacrificing of the interest of the subject on the one hand, or of the revenue on the other, through undue influence, private solicitation, personal friendship or regard. Fourthly, it was charged that the great increase in revenue officers would be a menace to the country. This objection, however, was greatly magnified because the change in tobacco would mean an additional increase of only one hundred and twenty-six men. Lastly, it was claimed that the power of officers to search houses would be a great grievance. This objection, however, could not have any weight except through misrepresentation. All warehouses, cellars, rooms, and so forth, used for keeping tobacco, were to be entered at the inland office. These were indeed liable to the inspection of the officers, but no other part of the house could be searched without a warrant and a constable. The poor man would not be affected, because the price of tobacco would not change. The whole outcry that was being raised was, he thought, in favor of the fraudulent tobacco merchant. ${ }^{2}$

The opposition in the House had long been preparing for the contest. The attack was to be made, not against the scheme, but against Walpole. He had kept down many jealous contestants for favor and power, and these were ready to use every possible means to compass his downfall. They were impatient for the bringing forth of the scheme, because by playing on the terms "general excise" they were confident that they would be sticcessful in causing Walpole's defeat. The feeling of

'Hansard, op. cit., pp. 1278-1281. 
impatience was shown at the opening of the session, in the speech of Sir John Barnard on the motion for the address. He said that there now seemed to be a great deal of jealousy without doors, as if something were intended to be done in this session of Parliament which might be destructive to liberty and detrimental to trade. ${ }^{\text {A }}$ few days later, in the debate on alienating part of the sinking fund, William Pulteney declared that there was another thing, a very terrible thing impending, a monstrous project, yea more monstrous than had ever yet been represented, that monster the excise, that plan of arbitrary power which was expected to be laid before the House. ${ }^{2}$ On the twenty-seventh of February, on Walpole's promise that he would be ready on that day fortnight to bring forth a motion to consider frauds in certain revenues, Sir Willam Wyndham said that the question was whether or not they should sacrifice the constitution to the prevention of frauds in revenue. ${ }^{3} \mathrm{He}$ was followed by Sir John Barnard, who said that the scheme at its first conception was for a general excise, but that it seemed afterwards to have been thought to be too much at once, and that therefore one or two branches were to be singled out in order that they might first be hunted down. ${ }^{4}$ When the scheme was presented, the following spoke against it: Perry, Methuen, Barnard, Heathcote, Pulteney and Wyndham. Their arguments were as follows: first, it was only a step toward a general excise, and in all countries excises of every kind were looked upon as badges of slavery; secondly, the increase of revenue, resulting from the change to excise, would give great arbitrary power to the crown; thirdly, the

${ }^{1}$ Hansard, op. ctt., p. II7I.

2 Ibid., p. 1203 .

"Ibid., p. 1233 .

Ibid., p. 1234 . 
commissioners, hearing all cases of excise, would rob the people of their right of trial by jury, thus directing a blow at liberty: fourthly, the patronage of the crown would be greatly increased by the additional number of excisemen, a fact that would be brought to bear at elections; fifthly, the frauds mentioned were greatly exaggerated, and the majority of them could be checked if the commissioners of customs would do their duty: sixthly, the laws of excise were very grievous to the subject, and many were the complaints of the cruel oppressions of the excisemen; seventhly, although the scheme would ease the lancled interests, it was only a bait to win over some refractory landowners and to set the landed interests at war with the trading interests." As we have seen, however, these objections were anticipated and answered by Walpole.

A few years before, Pulteney and several of his closest iriends had founded, for the purpose of attacking Walpole, a magazine called The Craftsman. This paper did its full share in exciting public clamor. The opposition made use of every possible means to rouse the general public; pamphlets flooded the country; public meetings were held in every part of the land; the people were told that Walpole intended to let loose that terrible monster, the excise, and that an army of excisemen would swoop down upon them, make them slaves and take the very food from their mouths. It was said that they would lose their liberty and be at the mercy of an absolute power, and that their houses would no longer be safe, but could be entered at any time by that terrible gorgon, the exciseman. Placards representing excise as a hideous vampire sucking the very blood of the people were 
scattered throughout the country. When Walpole introduced his scheme, the majority did not know its meaning or purpose, but were told and believed that it was the first step toward slavery. Almost immediately rioting began, and the popular clamors were increased by the imfiammatory speeches of the opposition. Within a week after Walpole's speech, the whole country seemed to be on the verge of revolt.

While the debate was in progress a vast number of people assembled at the door of the House. ${ }^{x}$ When Walpole rose to reply to the attacks of the opposition he was confronted, not only by a revengeful party in the House, but also by a clamorous, haranguing mob on the outside. He strongly resented the comparison of Epsom and Dudley to himself which had been made by the opposition, and declared that if he ever endeavored to. raise money from the people, or from any man whatever, by oppression and illegal means, or if his character should ever come to be in any respect like theirs, he should deserve their fate. His attention being attracted by the rioting without, he censured the opposition for being the cause of the clamors. He said that the people did not speak their own sentiments, but were played by others like so many puppets. They did not come to the doors of the House on their own accord, but very odd methods were used to bring them there. Circulars had been written and sent by beadles to every part of the city summoning the people, upon their peril, to come on this day to the House. They did not come, he asserted, as humble petitioners, but as mouth-pieces of a few members of the House. ${ }^{2}$

'There was likewise the greatest concourse of people in Westminster Hall, the Court of Requests and the Lobby that had been known for many years. London Magazine, 1733, March.

'Hansard, op. cit., pp. 1304-1306. 
The debate was continued until two o'clock in the morning, an hour at that time considered very late. The question was finally put in a motion by Walpole, and carried by a vote of two hundred and sixty-six to two hundred and five. The multitude remained to the last, and some claim that it had been designed to murder the statesman when he left the House. As he passed to his carriage some of the mob seized his garments, and had it not been for his son and General Churchill he would have been trampled under foot. ${ }^{\mathrm{T}}$

The committee's report, in four resolutions, was favorable to the scheme, and on March the sixteenth Sir John Turner reported the same to the House. ${ }^{2}$ After some debate each resolution was carried, and it was ordered that a bill be introduced embodying them. On April the fourth the excise bill was introduced and read the first time. Walpole, by the King's command, acquainted the House that His Majesty consented to such alterations in the subsidy on tobacco then payable to the civil list as they should think fit for the public service. ${ }^{3}$ Hereupon it was objected that some parts of the bill were not within the resolutions of the House pursuant to which the bill had been ordered to be introduced, and it was moved that the bill should be withdrawn, but this was defeated by a vote of two hundred and thirty-two to one hundred and seventy-six. A motion was made to adjourn, which was likewise defeated by a vote of two hundred and thirty-seven against one hundred and ninety-nine. But at last it was resolved that the bill

'Coxe, Memoirs of Sir Robert Walpole, vol. ii, p. 236.

' Hansard, op. cit., p. I3I3; Journal of House of Commons, vol. xxii, pp. $92-93$.

"Journal of the House of Commons, vol. xxii, p. 104. 
should be read a second time on the eleventh instant, and this was carried by a majority of thirty-six. ${ }^{1}$ It is eviclent, therefore. that there was a strong opposition to the bill-an opposition that was increasing to such an extent that, if Walpole had persisted and not withdrawn his measure, it is hard to say what the result would have been.

The country was in a very unsettled state and the Stuarts were taking advantage of every opportunity to further their interests. Ardent Jacobites were jubilant, and proclaimed that it would not be long before the Pretender would be on the English throne. Numerous petitions were poured into the House of Commons. Effigies of Walpole were burned in scores of cities, while the country seemed to be swaying toward the House of Stuart. At the court, the Queen became anxious concerning her own safety, and appealed to her friend Lord Scarborough for advice. He said that the bill must be dropped: "I'll answer for my regiment against the Pretender, but not against the opposers of the excise." The Queen after some hesitation, with great emotion and in tears said: "We must drop it."

On the morning of April the tenth, the city of London, through its officials, presented a strong petition, asserting that the bill would deliver the most fatal blow which had ever been given to trade and navigation." A long debate ensued, and petitions from other large cities were filed. In the evening, Walpole called a meeting of his closest friends and consulted them as to what was to be done when the bill should be taken up on the morrow. The majority were in favor of perseverance. He paced

'Journal of the House of Commons, vol. xxii, p. 104.

thid.. p. 108. 
up and down the room and heard the opinion of every one. Finally, after much thought, he said that he meant well, but that, in the present inflamed temper of the people, the act could not be carried into execution without an armed force, and that there would be an end of the liberty of England if the supplies were to be raised by the sword. If they decided to proceed with the measure, he would instantly request the King's permission to resign, for he never would be the minister to impose taxes at the expense of blood. ${ }^{\text {r }}$

On the opening of Parliament on April the eleventh, petitions were presented from the city of Nottingham, alleging that the bill if passed would encroach on the liberties and properties of the petitioners; and from Coventry declaring that the scheme would be prejudicial to the trade of the nation in general and the city in particular." Every one was eagerly waiting for the contest to commence anew. The order of the day was read for the second reading of the famous bill and greatly to the surprise of the opposition. Walpole moved that the bill should be read a second time on the twelfth of June. ${ }^{3}$ By this motion, it was apparent that the measure was designed to be dropped. Many members, who had from the beginning strenuously opposed it, wished to have it rejected. This proposition, however, did not come to a question, and the motion was agreed to. This meant the abandonment of the scheme, because it was understood that the House would be prorogued before that date. ${ }^{4}$ On the thirteenth of April, the day appointed for

'Coxe, Metnoirs of Sir Robert Walpole, vol. ii, p. 239.

'Journal of the House of Commons, vol, xxii, p. II4.

Ibid.

'The House, on June the ninth, was adjourned until June the thirteenth, and then prorogued until July the twenty-sixth; Journat of the House of Commons, vol. xxii, pp. 201-204. 
the further consideration of methods for improvement of revenue frcm tobacco and wine, ${ }^{1}$ a motion for the House to consider the matter on the fourteenth of June passed with a small majority. ${ }^{2}$ By this motion, that part of the excise scheme which referred to the duties on wines, was entirely abandoned. On the twenty-fifth of April, Mr. Perry succeeded in getting a committee appointed to investigate the frauds in the customs. The committee made a voluminous report in June, which was, however, not followed by any legislation. Thus we have the sad end of what had promised to be a great reform and a boon to the trade of the nation.

When the news of the abandonment of the measure reached the people, they became frantic in their rejoicing. The monument in London was illuminated, bonfires blazed in every county; and friends of the measure, if discovered, were subjected to all kinds of brutal insolence. The excitement soon calmed, and confidence in the government was quickly restored. In the next session of Parliament, Pulteney insinuated that the excise scheme was to be revived. Walpole answered: "As to the wicked scheme, as the honorable gentleman was pleased to call it, which he would persuade us is not yet laid aside, I, for my part, can assure the House I am not so mad as ever again to engage in anything that looks like an excise, though in my own private opinion I still think it was a scheme that would have tended very much to the interest of the nation." 3

What were the causes of the the failure of the scheme, or in other words, what gave rise to the great opposi-

'It was ordered on April the fourth.

"Journal of the House of Commons, vol. xxii, p. 116.

${ }^{3}$ Hansard, of. rit., vol. ix, p. 254. 
tion in the House, and among the general public? First, the energy and activity displayed by the opposition in the House and without. Secondly, the united opposition of the wealthy tobacco merchants, who not only used their own influence against the scheme, but furnished large sums of money to flood the country with pamphlets, placards and public speakers. Thirdly, the instilled hatred of the people to excise and everything that was connected with the name. Fourthly, the new theories of the incidence of excise which changed the views of many believers in the excise system. Fifthly, the universal belief that this was a step toward a general excise system. And lastly, the lukewarm support of many wealthy landowners who were in favor of seeing the land tax reduced to one shilling, but were very much against its abolition.

One feature of the scheme that attracted many later writers was the extension of the warehouse system. In this Walpole was years in advance of his times, for it was not until the latter part of the century that Pitt succeeded in introducing to an extended degree the system that Walpole designed. ${ }^{x}$ Walpole's aim was to improve and to extend the warehouse system to many articles of general consumption. He was unfortunate in introducing his scheme of reform so soon after the excitement caused by the revival of the salt duties. The opposition branded it as an excise for the purpose of attack. If he had omitted the frequent use of the word "scheme," " and labeled his measure as the extension of the warehouse system, the opposition would not have been so great, and the chances of success would have increased a hundred fold.

129 Geo. III, c. 68.

${ }^{2}$ In his speeches, he frequently spoke of his plans as a scheme. 
Warehouses were introduced in I 700 for the wrought silks of Persia, China and India. ${ }^{\prime}$ In order to give greater security to the revenue arising from duties on pepper, the warehouse system was, in I709, extended to that commodity. ${ }^{2}$ A half of the duty was to be paid on warehousing the pepper, and subsequently, if the pepper were taken out for home consumption, the other half was to be paid, but if the pepper were exported, no further duty was demanded. Two years later the system was extended to tea and coffee, ${ }^{3}$ but this was now permissive and not obligatory. Walpole, in 1724 , changed certain duties on tea, coffee and cocoanuts, and made the warehousing of these commodities compulsory. ${ }^{4}$ The "excise scheme" was simply a plan to prevent frauds in the customs of tobacco and wine, by extending to these commodities the compulsory warehouse system. It was the system that later proved exceedingly beneficial to English trade and commerce, and which was so highly praised by Tucker, lauded by Smith, and idolized by Pitt.

In Walpole's defence of his excise scheme, we notice that his previous warm support of general excise had grown cold, and that his views regarding the efficacy of the tax had changed. In his answer to the charges of contemplating a general excise, he said that if one commodity were more within the direct aim of fiscal imposition than another, it was a commodity of luxury that depended for its use on custom or caprice, and was by no means essential to the support or the real comfort of human life. ${ }^{5}$ The discussion over the revival of the salt $\operatorname{tax}$ seems to have changed his views regarding the com-

' $\mathrm{II}$ and $\mathrm{I} 2 \mathrm{Wm}$. III, c. 3 .

'8 Anne, c. 7.

8 ro Anne, c. 26.

'ro Geo. I, c. ro.

- Hansard, op. cit., vol. viii, p. 1270. 
modities that should be taxed. He then contended, as we have seen, that the tax which was the most equal and the nost general was the most just, and that in case of a levy on a real necessary of life the poor man contributed such a small trifle that it would hardly bear a name." From this it followed that the most general tax, and therefore the most just, was one on the necessaries of life. He apparentiy realized that such a tax was an unjust burden on the poor man, and this led him to a tax on luxuries. In a pamphlet in support of his excise scheme he definitely stated his opposition to a tax on the necessaries of life: "These men have rung the changes upon a general excise, and excise npon daily bread and everything necessary to the subsistence of life; this indeed would be a monster frightful enough, a hydra with heads and teeth sufficient to destroy the nation." " In the same pamphlet he gives his unqualified support to a tax on luxuries: "Nowhere can a tax be more reasonably made than upon commodities not necessary to human life, but only used through custom and luxury. All reasonable men agree that taxes upon luxury are the most just taxes." 3 Whereas he formerly held that the tax paid by the poor laborer was such a tritle that it was not a hardship, he now recognized it as a burden, and one from which the poor man should be free.

In speaking of the effect of an excise upon the food of the poor laborers, he said that an excise upon food and the necessaries of life would indeed be heavy upon them, as it would raise the price, and consequently lessen the quantity of their daily bread: a barbarous pro-

'Hansard, op. cit., vol. viii, p. 945.

-Walpole, Some Considerations on the Public Reterites, p. 19.

Ibid., pp. 16-17. 
ject never meant. ${ }^{\mathrm{r}}$ As a result he adopted a new scheme of taxation. Commodities were to be divided into taxed and untaxed: the untaxed to comprise the principal necessaries, and the taxed the luxuries of life. The poor man would be relieved of a burden which would fall on those more able to pay. Among the luxuries he favored those of wide consumption. His aim was to relieve the poor laborer from taxes on his daily food, or in other words to give him the free breakfast-table that Dr. Johnson claimed was the badge of national liberty." Thus the excise controversy resulted in greatly modifying the economic views of Walpole. It caused him to break away from old traditions in order to adapt his method of taxation to new conditions, but his change in thought and method came so suddenly that the people failed to realize it. In the face of all his denials, they persisted that he was following out his old policy and perfecting his plans of a general excise. We, however, realize that he was sincere in his denial of a general excise, and that his scheme, if carried out, would have greatly benefited landowner, trader and laborer.

The controversy over the excise scheme was in its nature a political struggle. The business of the opposition was not to alter, amend or improve, but to oppose and raise a ferment. Their chief end was to defeat Walpole by any means, fair or foul. The discussion in the House was limited to charges of a general excise and its resulting evils. More attention was paid to arousing the people by vindictive speeches than to discussing the theory and incidence of the tax. The discussions, in fact, were not productive of any new theories of the justice or the incidence of taxation.

\footnotetext{
'W'alpole, ibid., p. 6. $\quad$ "Boswell, Life of Johnson, vol. ii, p. 48.
} 
Hundreds of pamphlets were written and scattered throughout the country, the vast majority of which were of a purely political nature. Pamphlets worthy of mention are relatively few as compared to the number written. The most prolific pamphleteers were Caleb D'Anvers or Nicholas Amherst and William Pulteney. Amherst, who was the publisher of "The Craftsman" and a voluminous writer, quoted and agreed with Mr. Locke, that taxes ultimately fell on land. ${ }^{\mathrm{T}}$ William Pulteney, who took an active part in the controversy and contributed many pamphlets, was a devout follower of Locke, and did not make any contribution to theory. Vanderlint, without reference to the excise controversy, reached the conclusion that the soil was the chief source of wealth, and advocated laying the chief burden of taxation on land. " An anonymous pampleteer insisted that a land tax was shifted to the consumer, and therefore the lower the land $\operatorname{tax}$ the lower the price of provisions. ${ }^{3}$ Many who favored the excise scheme did so because they desired to see the tax on land lessened. ${ }^{*}$ At this time few distinguished between the landlord and the tenant; the first to make a clear distinction was Mr. Plummer, who said that the land tax took from the landed gentleman a part of his rent yearly, but that the salt tax was a charge upon trade and manufacture, and would at last disable his tenant from paying him any rent. ${ }^{5}$

In the theory of taxation the discussion of 1732 resulted in dealing a death-blow to the general excise. The inequality of the tax was henceforth recognized, and in

${ }^{1}$ Amherst, Arguments against Excises, part i, p. 63.

${ }^{2}$ Vanderlint, Money Answers All Things.

"Quoted in Seligman, Incidence of Taxation, p. 80 and note.

'Ibid., p. 82 and note. 'Hansard, op. cit., p. 947. 
its place a tax on luxuries received the greatest attention. Walpole himself was a convert to this form of tax. The scheme of a single tax on land received a champion, but he reached his conclusion independently of the excise controversy. The doctrine that land was the chief source of all wealth was advanced by Cantillon, whose pamphlet was written about this time. ${ }^{\text {I }}$ Regarding the incidence of the tax, the theory that it was shifted to the consumer and was an unjust burden on the shoulders of laborers received the greatest attention. Yet the theory that all excises fell ultimately on land secured a large following. So that from an economic point of view it might be said that the discussion was fruitful.

In 1736 an excise of twenty shillings a gallon was imposed on spirituous liquors, ${ }^{2}$ but this was for the purpose of prolibition and not of raising revenue. The following year the excise on sweets was abolished, and in lieu thereof a new excise of twelve shillings a barrel was imposed.3 During the renaining years that Walpole was in power he added only one excise, and that was for the purpose of furthering the public welfare.

Before concluding, it will be necessary to mention three slight changes in the inland duties. In 1729 an act imposed an annual tax of twenty pounds upon every retailer of compound. spirits in quantities less than a gallon.4 Seven years later the additional duties upon stamped vellum, parchment and paper were continued for four years, from $1742,{ }^{5}$ and an annual license of fifty pounds was demanded from all dealers who retailed spirituous liquors in quantities less than two gallons. ${ }^{6}$

' The pamphlet was not published until 1755 .

" 9 Geo. II, c. 23.

'1o Geo. II, c. 17.

2 Geo. II, c. 17.

${ }^{5} 9$ Geo. II, c. 32 .

${ }^{\circ} \mathrm{g}$ Geo. II, c. 23. 
In the sphere of taxation, the twenty years of the administration of Walpole are important. He was the first financier to be influenced in his policy by economic principles, and the first statesman to take any interest in the theoretical consideration of taxes. His speeches in behalf of the land tax showed a careful study of the economic basis of the tax, and his policy throughout was consistent with his economic views. At first, he was a firm believer in a general excise, and ardently supported it as the most equal and least burdensome means of raising a revenue; but as the result of the discussion over the revival of the salt excise, a change took place in his belief. He discarded the general excise as his ideal tax, and adopted one on luxuries. Whereas he had originally contended that a poor man should pay something for the support of government, and that what was so paid in an excise upon necessaries of life was not a burden, he now after 1732 looked upon the excise as a grievance, and desired to see the necessaries of life freed from all excises or duties. Walpole's scheme of extending the warehouse system, if it had been accepted, would undoubtedly have been a great triumph for him. It would have resulted in suppressing fraud, simplifying taxes, aiding trade and lessening the burden on the poor laborer. But Walpole, like other great reformers, was in advance of his time; and it took more than half a century for the people to realize the great advantage of his plan. Although Walpole was defeated in his reform, he will none the less go down in history as the first great reformer in taxation, and the first statesman to be guided in his policy by economic principles. 


\section{CHAPTER IV \\ Reforms IN THE TARIFF}

ThE English system of customs since the Commonwealths is the outgrowth of three acts $;^{x}$ the first, passed in I660, was for granting a subsidy of tonnage and poundage, the second, the same year, for the encouragement of shipping, and the third, two years later, for preventing frauds and regulating abuses in the customs. According to the first, every tun of wine imported or of beer exported paid a certain definite sum, which was called tonnage; certain goods imported or exported paid a fixed rate in the pound, according to their values in the book of rates, and this was termed poundage. All the customs, with the exception of tonnage and a small duty on woollens exported, were under the simple regulations of poundage. This system did not remain long without alteration, for in 1670 the duty on corn imported was changed from poundage to a certain rate per quarter, varying according to the different kinds of corn, and the circumstances of importation. ${ }^{2}$ Three years later, whale fins and whale oil underwent a similar alteration. ${ }^{3}$ In the reign of James II, new duties on wine, vinegar ${ }^{4}$ and tobacco ${ }^{5}$ were

'12 Chas. II, c. 4; 12 Chas. II, c. 13; I4 Chas. II, c. Ir.

${ }^{2} 22$ Chas. II, c. I3. $\quad{ }^{3} 25$ Chas. II, c. 7.

'I Jas. II, c. 3. Granted for eight years, but continued by different acts until by 9 Anne, c. 2I, they were made perpetual.

${ }^{3}$ I Jas. II, c. 4. Granted for eight years, continued by different acts and made perpetual by 9 Anne, c. 2I. This first included a duty on sugar, but this was repealed by 2 W. and M., c. 5 . 
added; the first two were based on tonnage and the third was a certain rate per pound weight. During the reigns of William and Anne, many new impositions were added, so that by I $_{2} 2 \mathrm{I}$ there were few articles that could be imported or exported without paying a duty.

One of the grievances presented at the Good Parliament in 1376 was that England suffered from the loss of precious metals. This was soon followed by a statute prohibiting the exportation of coin and bullion. From time to time acts were passed limiting trade to those countries where England gained by the exchange of commodities; prohibiting foreign goods from competing in the home market; and compelling the consumption of home products. By so doing the people believed that the gold that came into the country would be retained, and England would amass wealth and become powerful. The followers of this theory were called bullionists, and their views were dominant until after the middle of the seventeenth century.

The navigation laws gave assistance to shipping, but as yet the people paid little heed to the development of home industry. In 1663 an act was passed permitting the exportation of bullion, and marking the triumph of the mercantilists over the bullionists. Every person was allowed to export from England, duty free, any kind of foreign coin or bullion of gold or silver, provided that he make an entry in the custom house of the port from which it was exported. ${ }^{x}$ Silver continued to flow out of the country in such great quantities that by the time of the accession of William III the scarcity of the metal had become so great as to cause a petition from the goldsmiths of London to the House of Commons, com- 
plaining that, because of the exportation of silver, bullion had become so scarce that not only the petitioners had been injured in their trade, but the mint itself had been stopped from coining. The petition was referred to a committee of the House of Commons, and the remedies proposed were either a prohibition of export, or the enhancing of English moneys. Three measures were presented to the House for the prohibition of export, but all were lost. Their defeat was due to the activity of the members of the East India Company, who saw in prohibition a great loss to their trade. The prohibitive bullion act had been disadvantageous to the East India Company, so that when an agitation began for its re-establishment, the leading members became very active in promulgating the theory that England had to gain her wealth by a favorable balance of trade, and that bullion should be allowed free exportation. The war against the bullionists was waged by Mun, Child, North and the economists, Davenant, Petty and Barbon. They contended that wealth was secured by a favorable balance of trade, and that it should be the duty of the statesman to adopt measures that would assure this.

The old subsidy of 1660 imposed duties on corn, woollen manufactures and several other commodities. The people believed the foreign consumer paid the duty, and it was some time before the landed interests realized that the export duties were injurious to them. In I689 a bounty was granted on corn exported, ${ }^{\prime}$ but it was not until I 700 that the export duty was repealed." The landed interests controlled the Parliament of King William, and passed many laws beneficial to their class. They contended that agriculture was the prevailing oc- 
cupation, and that a favorable balance of trade could be secured by fostering it.

North, the most liberal of the seventeenth century economists, said that the source of wealth was industry applied to land or manufacture, and that that country was the richest which "raiseth more fruits or maketh most of manufacturing." Agriculture and manufacturing were encouraged for the purpose of causing a greater inflow of the precious metals by means of a favorable balance of trade. Encouragement had been given to agriculture, and commencing with the eighteenth century special care was taken to aid manufactures. In 1700, the woollen manufactures were benefited by the repeal of duties on the exportation of the finished articles. ${ }^{x}$ Later, provision was made for the repayment of the excise on all excise commodities exported.

The manufacturing intercsts were growing stronger and competition abroad was increasing at a rapid rate. If England were to continue her favorable balance of trade, steps must be taken to foster manufactures; and as a consequence manufactures, in place of agriculture, attracted the attention of the statesmen of the period. Cheap food, cheap labor, cheap raw material, was the cry. This program had been advocated by the economists at the close of the preceding century. Commencing with I72I, we enter upon the industrial stage of mercantilism. Every advantage had to be given to the manufacturers to enable them to produce as cheaply as possible. They had to be protected at home from competition with foreign finished products; free exportation of finished articles had to be secured; and where possible, encouragement had to be given by bounty and allowance. Industry, in 
short, had to be regulated to further trade. Such was the policy of the period and hence, in place of fewer regulations, we have more, all aiming to secure a favorable balance of trade, to encourage an inflow of gold and to increase national power.

In the King's speech on the opening of Parliament, on the nineteenth of October, I72I, we see the policy clearly outlined. After congratulating the Peers and the Commons on their diplomatic success abroad, he continued:

In this situation of affairs, we should be extremely wanting to ourselves if we neglected to improve the favorable opportunity which this general tranquillity gives us of extending our commerce, upon which the riches and grandeur of this nation chiefly depend. It is very obvious that nothing would more conduce to the obtaining so public a good, than to make the exportation of our own manufactures and the importation of the commodities used in the manufacturing of them, as practicable and easy as may be; by this means, the balance in trade may be preserved in our favor, our navigation greatly increased and greater numbers of our poor employed. I must therefore recommend it to you, Gentlemen of the House of Commons, to consider how far the duties upon these branches may be taken off and replaced without any violation of public faith or laying any new burden upon my people, and I promise myself, that by a due consideration of this matter the produce of those duties, compared with the infinite advantages that will accrue to the kingdom by their being taken off, will be found so inconsiderable as to leave little room for any difficulties or objections. ${ }^{\prime}$

The object in view, therefore, was to secure a favorable balance of trade; to increase shipping; to assist manu-

' Journals of the House of Commons, vol. xix, p. 646; Hansard, op cit., vol. vii, p. 913 . 
facturing; and to give employment to a greater number of laborers. All these were the essential doctrines of the mercantilistic school, the chief aim of which was to develop national power. The question as to the attaining of wealth was one that puzzled financiers for centuries. England being an insular power, it was natural that she should first look to shipping as the one great means of obtaining treasure. Its regulation, so as to give advantage to English commerce, was the chief aim of statesmen in their domestic and foreign policy. This was followed by assistance given now to agriculture and now to industry, to obtain the much-sought-for favorable balance.

Walpole, in the session of Parliament just opened. carried into effect this policy of encouraging industry by making many sweeping reforms in the tariff. It was enacted that all goods of British manufacture, with only a few exceptions, should be exported free of duty. ${ }^{x}$ This was the first attempt since I700 to repeal the export duties levied in 1660 , and was the first great step toward developing industry. Industry, more than agriculture, now occupied the attention of the statesmen. Further assistance was given, in the repeal of the import duties upon numerous drugs and goods used in dyeing, but in case such goods were exported they were to pay a duty of six pence upon every twenty shillings. The policy had been to increase duties, not to abolish them. This was the first attempt since the import duties were im-

' 8 Geo. I, c. I5, sec. 8 . The exceptions were-alum, lead, lead ore, tin, leather tanned, copperas, coals, wool-cards, white woollen cloths, lapis calaminaris, skins of all sorts, glue, coney hair or wool, hares' wool, hair of all sorts, horses and litharge of lead. A good account of export and import duties is found in Saxby, British Customs, London (1757), pp. 77-302. 
posed in $\mathbf{I} 660$ to relieve of duties articles used in manufacturing, although the scheme had received the support of economists for nearly half a century.

The act was also the first step toward the simplification of the customs. These were in a very complicated state, sometimes as many as ten or twelve different duties being levied on a single article. Several changes were made and many duties were lowered. Beaver skins were the first to be affected. They were rated, according to the old book of rates, at six shillings eight pence per skin, according to which many duties were payable. ${ }^{x}$ After the twenty-second of March, I722, the skins were to be treated at the rate of two shillings six pence, and it was provided that there should be paid for every skin six pence and no more, and in case of exportation a drawback of half the duty was to be allowed. The manufacturers of hats and furs were greatly benefited by this change. Pepper, imported directly from the place of growth in English-built ships, was valued in the book of rates at one shilling eight pence per pound, and in the same fashion several duties which amounted to one shilling eleven and one-half pence per pound ${ }^{2}$ were reduced to four pence per pound. Mace had its valuation changed from twenty to six shillings per pound, and its duties reduced from ten to three shillings, while cloves and nutmegs had their values lowered from ten and eight to four and three shillings per pound, and their duties

'The duties payable on beaver skins: A. Old subsidy 4d. per skin; B. Further subsidy 4 d. per skin; C. One-third subsidy $1 \frac{1}{3} d$. per skin; D. Two-third subsidy, $2 \frac{2}{3} \mathrm{~d}$. per skin; E. Additional impost $4 \mathrm{~d}$. per skin-total $16 \mathrm{~d}$. per skin.

${ }^{2}$ The following were the duties on pepper: A. Old subsidy one-half pence per pound; B. Further subsidy Id. per pound; C. One-third subsidy $1 / 3$ d. per pound; D. Two-thirds subsicly $2 / 3 \mathrm{~d}$. per pound; E. Old impost, 3d. per pound; F. New duty is. $6 \mathrm{~d}$. per pound-total is. ir $1 / 2 \mathrm{~d}$. 
lessened from five and four to two and one and one-half shillings per pound, respectively. Upon exportation, the same proportional drawback as previously allowed was to be paid. This act was the first important step in tariff reform, and the first initiative in the simplification of the duties. The same year, the duty upon all salt used in the curing and making of red herring was repealed and, in place thereof, a duty of one shilling eiglit pence per thousand was levied on all such herring entered for home consumption. In the case of white herring, the duty on salt was repealed, and in its place a duty of three shillings four pence per barrel of herring for home consumption was levied. ${ }^{2}$

The coinage duty, so called because the proceeds were to defray the expenses of the mint, was first granted in 1666. 3 It was an additional duty of ten shillings per tun on all wine, vinegar. cider, beer, brandy and strong waters imported into England. The duty was continued by several acts to the first of March, 1723 ; in that year it was continued for a further term of seven years, ${ }^{4}$ and by subsequent acts, was further continued. ${ }^{5}$ By the same act, the duties payable ad valorem on books, were abolished, and in their stead, a duty of fourteen shillings per hundredweight on all bound books imported was imposed.

In 1723 an important step was taken toward simplifying the management of the customs of England and Scotland. These had originally been farmed out. The tyranny of the farmers, however, became so oppressive that importers and financiers combined and succeeded, in $167 \mathrm{I}$, in transferring the collection of duties to Boards of

18 Geo. I, c. 4.

49 Geo. I, c. I9.
28 reo. I, c. I6.

${ }^{3}$ i 8 Chas. II, c. 5 .

${ }_{4}^{5}$ Geo. II, c. I2; i I Geo. II, c. 5 . 
Commissioners. ${ }^{1}$ By the Act of Union between England and Scotland in 1707 the duties were put under the direction of two different commissions, one of which was to have charge of the management of customs in England while the other controlled those of Scotland, each being vested with like powers. It was enacted in 1723 , that after the first of June the king might, if he judged it advantageous to trade, put the customs of Great Britain under one commission. ${ }^{2}$ This was a great advance towards England's present system.

England being favorably situated for fishing, a great number of people were engaged in that industry. Many believed that the industry should be fostered, if for no other purpose than to train men in hardiness and to furnish a supply of recruits for the navy. The herring fisheries had been favored, and now it was decicled to assist the whale industry-a policy which was hastened by the increasing demand for whalebone and whale oil. It was at that time necessary for England to look abroad for her supply, and large quantities were imported. It was thought that this could be overcome by giving an inducement to Englishmen to engage in the Greenland whale fisheries, and as a consequence it was enacted in I724 that the products of all whales caught on the Greenland banks should, for a period of seven years, be imported duty-free. ${ }^{3}$ In 1726 the privilege was extended to Davis' Straits, ${ }^{4}$ and six years later seal and fish products caught in these two waters were to enioy, for a period of nine years, the same privileges. ${ }^{5}$

Walpole's attention was next directed to the scandals

'The farming system continued on a small scale until 1707.

${ }^{2} 9$ Geo. I, c. 2 I.

'12 Gco. I, c. 26.
${ }^{3}$ io Geo. I, c. I6.

${ }_{5}^{5}$ Geo. II, c. 28 . 
and loss of revenue arising from the practice of appraising falsely the value of imported articles not mentioned in the old book of rates of r66o. The book, of course, did rot include all articles, and those not enumerated were to pay one shilling in the pound on their sworn value. This process, however, proved very unsatisfactory, as is seen from the preamble to the Customs Act of 1724 , where it is stated that it had been found by experience that on many articles imported and not in the book of rates, very unequal values had been sworn to by the importers; some persons greatly undervaluing the same, to the detriment of the revenue and the discouragement of the fair trader. Therefore, in order to remedy these abuses, it would be necessary to issue a supplementary book of rates, which would state the official value of a large number of articles either omitted from the book of 1660 or not then in use. An additional book, including the rates on articles not mentioned in the old, was accordingly made up, and it was enacted that the duties on goods not mentioned in the old should be paid according to the additional book of rates.' In case of goods imported and not rated in either book the luty was to be paid according to the price sworn to by the importer. These two books of rates remained in force until 1787 , when Pitt reduced customs and excises

${ }^{1}$ Some of the values from the new Book of Rates:

Dried plums, 6d. per lb.. pig iron, in 2 lbs., $\mathscr{E}$,

lard, per lb., 3d., pears, per bu., 5s., bologna sausage, per lb., Is., rum, per gal., Is. 8d., sheep's skin, 5d., hard soap, per II2 lbs., $\mathscr{6} 3$, hay, per load of $2016 \mathrm{lbs}$., $£^{2}$, lime juice, per gal., 6d., chestnuts, per bu., 5 s., pencils, per gross, 12 doz., 10s., clover seed, i 2 lbs., Ios., millet seed, 112 lbs., I6s., sheep's wool, per pound, 3 d., soft soap, per i 2 lbs., 6 I Ios. 
to a codified form, the articles being rated at specific duties, and books of rates ceasing to be necessary. The same act, known by some as the Customs Act of 1724 , repealed the additional duty of twenty per cent. on drugs imported into England. It was claimed that, because of excessive duties, these articles were smuggled into the country in large quantities, so that it was impossible for a fair trader to import them and compete with the fraudulent dealer. Aid was also given to the paper manufacturer, who was now allowed to import free of duty all old rags, old rope and so forth, used in the manufacture of paper.

The reason for the reduction of import duties had been either to give cheaper raw materials to the manufacturer or to prevent smuggling. The latter purpose caused the repeal of part of the duties on snuff in 1726 . The additional duty imposed on that commodity in $1710,{ }^{2}$ was repealed, and snuff from the British and Spanish colonies in America was rated at two shillings six pence, and from all other parts, except France, at five shillings per pound, according to which rates it was to pay the duties to which it remained liable. ${ }^{3}$

The manufacturers were in need of cochineal for coloring purposes. The supply was limited to the Spanish West Indies, and at this time, England and Spain were not on very friendly terms. Some inducement had to be given to encourage the importation of the commodity, or the manufacturers would suffer. Accordingly in 1727 an act was passed allowing its free importation for the period of six months from the twentieth of May of that year.4 At the end of that time the privilege was not

127 Geo. III, c. I3.

38 Anne, c. 7; this duty amounted to 3 s. per pound.

${ }^{3}$ I2 Geo. I, c. $25 . \quad$ 'I3 Geo. I, c. 25. 
continued, but in I729 it was revived for one year, ${ }^{\mathrm{I}}$ while in 1734 it was again revived for seven years, and the same privilege extended to the importer of indigo. ${ }^{2}$ At the expiration of that time, the privileges were further continued for a period of seven years. ${ }^{3}$ As the manufacturers used a considerable amount of these conimodities, they were benefited by the free importation.

Great frauds had been cliscovered in the importation of wine lees, the government being robbed of many thousands of pounds annually. Large quantities of wine were imported, mixed with and entered as lees, and were afterwards drawn off and sold as wine. Since the lees paid a much lower duty than the wine, the revenue from wine suffered. In order to remedy this evil it was enacted that after the twenty-fourth of August, I 728 , the duties on wine lees should cease, and in future the commodity imported should pay the same cluties as wine, and no drawback should be allowed on the exportation of the the article. ${ }^{4}$

We thus note the policy to develop every branch of industry that would tend to increase trade as the path to material wealth and power. Attention was now drawn to the demand of aid from the importers and cutters of precious stones, whose business had greatly increased, and who now demanded abolition of import duties on precious stones. In I733 it was enacted that after the tenth of April of that year all diamonds and precious stones should be exported and imported free of duty.5 The preamble states that the country had become a market

12 Geo. II, c. 28.

${ }_{7}^{2}$ Geo. II, c. 18 .

${ }^{3}$ I4 Geo. II, c. 34.

"I Geo. II, sess. 2, c. I7.

${ }^{3} 6 \mathrm{Geo}$. II, c. 7; this did not affect the act of 9 and Io Wm. III, c. 44, which imposed a duty on all precious stones imported into England from places mentioned in the Charter of the East India Company. 
for diamonds and other precious stones whence foreign countries were supplied; great numbers of rough diamonds were sent from abroad to be polished and cut, and there was reason to believe that if the importation were made easier the trade would greatly increase.

The failure of the Excise Scheme put a damper on Walpole's tariff reforms. From its defeat till the end of his administration we have only one slight change in the customs. French oysters paid an ad valorem duty according to the value sworn to by the importer. This practice was declared to be detrimental to the public revenue and disadvantageous to the English oyster industry. Accordingly in I737 it was enacted that in future French oysters should be rated at seven pence a bushel, and the duty be paid according to that value. ${ }^{\text {I }}$

Throughout the entire mercantilistic period the chief aim of the government was the maintenance of national power. It was not the individual but the nation that was the centre of all legislation, the individual being only the means to increase national wealth and power. As the one great source of obtaining wealth was trade, the shipping interests were the first to be protected and assisted. After shipping, agriculture received the greatest attention. England's wealth increased and capital began to be applied more freely to manufacturing, and we thus enter upon the last stage of mercantilism. It was industry that had to be encouraged and regulated in order to secure the much-desired balance of trade. Competition abroad was keener, and it was realized that England had to produce more cheaply if she wished to retain or to increase her commerce. Assistance, there-

${ }^{1}$ Io Geo. II, c. 30. For a good historical account of taxes from 10661727. vide, Stevens, Historical Account of the Taxes, London, 1733. 
fore, was necessary for manufacturers. The two first obvious means that presented themselves were relief from export duties on English-made goods and cheaper raw materials. Walpole accordingly, at one sweep, abolished nearly all the export duties which had been in force for well nigh three-quarters of a century, and also allowed many drugs that were used in dyeing to come in free of duty. But in order that their exportation might not assist foreign manufacturers they were made subject to an export duty. From time to time duties on raw materials were abolished, but we do not find the abolition of a single import duty on a finished product that would compete witl English-made goods. The great aim was to assist the manufacturer in order that he might successfully compete in the foreign market, and thus assure a favorable balance of trade.

Owing to the urgent need of revenue during the reigns of William and Anne a number of excessive duties had been levied. An extensive system of smuggling resulted. In many cases it was impossible for the honest merchant to pay the duty and to compete with the clandestine trader. At no time in English history was smuggling so dominant and carried on so openly as at the close of the first quarter of the eighteentl century. The high duties had rendered it very profitable, and few efforts had been made to check it. Not only were scores of smugglers made wealthy at the expense of the public revenue, but it was scarcely possible for an honest merchant to do business. Walpole knew that the public revenue suffered heavily each year on account of the extensive smuggling. He realized that the illicit trade could be checked either by lowering some of the excessive duties, so as to make it unprofitable, or by better regulations for the collection of the cluties. He therefore, in his 
tariff reforms, wished not only to encourage industry, but also to augment revenue by diminishing smuggling.

Soon after Walpole came into power he passed an act to check the clandestine trade. The preamble states that the laws already made to prevent the secret landing of prohibited and unaccustomed goods had been found insufficient for that purpose. It was notorious that such infamous and pernicious practices were continued in open defiance of the laws, to the great diminution of the public revenues and the discouragement of honest traders. In order to remedy part of these evils it was enacted that no brandy, arrack or spirits should be imported after the twenty-fifth of March, I722, in any vessels of less than forty tons burden, and that any violation of this act should be punished by forfeiture of the ship and cargo. It was also declared that many small boats were used for the clandestine landing of goods, as well as in the exportation of wool. To prevent these abuses it was further enacted that no small boats with more than four oars should be allowed above or below London Bridge, and in case of violation the punishment should be forfeiture. This act, however; did not apply to small boats in the service, of the King or admiralty, or attached to large merchant vessels. The act provided that all persons arrested and convicted of smuggling should be adjudged felons, and transported. If an offender arrested should discover two accomplices within two months of his arrest, he should receive forty pounds and be acquitted; and finally, if any person received goods knowing they were smuggled, and was found guilty of the same, he should pay a fine of twenty pounds. ${ }^{x}$ Thus

I 8 Geo. I, c. I8, enacted for two years; II Geo. I, c. 29, continued for three years; 2 Geo. II, c. 28 , continued for five years; 8 Geo. II, c. 2 I, continued for seven years. 
we have the beginning of a war against smuggling whicl was continued with great energy throughout Walpole's administration.

In 1725 the powers of the excise officers were greatly extended. In order better to secure the payment of the excise duties, the commissioners of excise were given the same power of searching vessels for articles subject to excise which were enjoyed by the commissioners of the customs.' Rigid laws were enacted for the sale of coffee and tea, and the adulteration of either was punished by a heavy fine. Strict rules were laid down for the making and sale of chocolate; any one found guilty of affixing a stamp on chocolate that had not paid the duty should be liable to a fine of five hundred pounds and imprisonment. Rigid regulations were also enacted for the making and sale of candles and soap, ${ }^{2}$ the powers of the excise officers being greatly increased. The regulations were so drastic, and the punishment for violation so severe that it was an easy matter for an officer to become oppressive. According to the petitions that were sent to Parliament, the officers were exceedingly tyrannical, a fact which no doubt, aroused the people against excise, and made it easy for the inflammatory speeches and pamphlets of I733 to excite them.

Laws had been previously passed liberally rewarding officers who seized goods that had been smuggled into the country. In order further to encourage officers to do their duty, the existing rewards were increased. It was enacted in 1726 that all the tea, coffee, tobacco, foreign brandy and exciseable liquors, seized and condemned for

II Geo. I, c. 30.

2 I I Geo. I, c. 30; the act went into the greatest detail, consisting of 44 sections. Cf. Pickering, Statutes at Large, vol. xv, pp. 262-288. 
violation of law, should be sold, and one third of the proceeds should go to the officer making the seizure. ${ }^{\text {' }}$ When so much smuggling was going on, such large rewards caused the officers to be active in performance of their duties. The final decision of all excise cases rested with the commissioners, and there was no redress for an honest trader who had been imposed upon. The excise officers accordingly became still more tyrannical, and many an honest trader suffered heavy losses through unjust seizures and forfeitures.

The makers of starch, it was declared, had been defrauding the government of a considerable amount of revenue. In order to prevent this, it was enacted that after the twenty-fourth of June, I73I, all starchmakers should use regular square or oblong boxes for drawing the green starch, the punishment for violation being forfeiture and a fine of ten pounds. Strict regulations were also made for boxing the starch, and if the rules were not followed, forfeiture and heavy fines were imposed on the offenders. Another fraud had arisen from the fact that great quantities of cocoanut shells and husks were imported and worked up so as to imitate either coffee or chocolate, and sold as such. To remedy this abuse, it was enacted that in future the shells or the husks should not be imported without the nuts. ${ }^{2}$

Although the laws against the clandestine trade in foreign goods were very strict, yet owing to the high profits

${ }^{1} 12$ Geo. I, c. 28; there were many minor regulations, as I. Tea not worth 5s. a pound, that was seized and condemned, should be burnt: 2. No officer should deal in tea, coffee, tobacco, etc.; 3. Vessels seized importing brandy, vinegar, etc., might be used by customs officers: 4. No dealer in cocoanuts should dispose of less than twenty pounds at one time. Ibid., pp. 318-33I.

${ }_{2}^{4}$ Geo. II, c. I4. 
they had very little effect in checking the practice. Many persons were hired by the merchants to carry on the illicit trade. These had been frequently caught and punished, while the real offenders had escaped, many of those convicted being the dupes of rich merchants. It was hoped that many of these persons might be reclaimed by clemency from offending in like manner in the future. For this purpose, it was enacted that all persons that had incurred any penalty by the clandestine running of goods before April the twenty-seventh, I736, should be acquitted, but that in case of a new conviction the offender should be punished for both the new and the old offence. The laws against clandestine dealing in prohibited goods were made more severe, and the punishment for violation more harsh. The rewards for the discovery of illicit goods were increased, and the powers of the officers in search and arrest greatly extended. ${ }^{x}$ It was, then, not the fault of the law that smuggling and fraud were not completely blotted out.

During this short administration of twenty years, more efforts were made to curtail smuggling and fraud than in all the records of English history up to this period. No man had been so firm an enemy of illicit trade, and none had so perseveringly tried to stamp out the evil practice as Walpole. He realized that as long as the duties were high, profits would be so alluring that it would be diffcult to check smuggling, not to speak of abolishing it. $\mathrm{He}$ accordingly lowered the duties on many articles in order to make smuggling less profitable. He also adopted the following means to check clandestine trading: extension of the powers of the customs and excise

${ }^{1} 9$ Geo. II, c. 35; the act consists of thirty-eight sections. Pickering, Statutes at Large, vol. xvii. pp. 63-8r. 
officers, strict regulation of the sale of excise commodities, strict laws of entry of imported goods, liberal rewards for discovery of illicit goods and conviction of offenders against excise or custom laws, heavy fines and severe punishments for violations of rules and regulations governing excises and customs. From the petitions that were from time to time sent to Parliament, it is evident that many of the officers were oppressive and tyrannical in the performance of their duties. Thus there arose a deep hatred of the excisemen, and of everything bearing the name excise. This made the people eager hearers and ready believers of the charges against general excise in the speeches and pampllets of the opposition during the fierce controversy of 1733 . We must, none the less, bear in mind, that Walpole's chief aim was to turn into the public treasury all that was rightly due it. For he thought that he could thereby increase the revenue to suci an extent as to be able, without levying extra taxes, to bring about reforms of benefit to landowners and manufacturers alike. 


\section{CHAPTER V.}

Bounties and the Colonial Policy.

In the preceding chapter we considered the abolition of export duties and the repeal of many import duties in order to assist the manufacturers. In the present chapter we shall take up the various other methods employed to encourage exportation, in order to increase trade and to assure a favorable balance. The commodities upon which England, during the seventeenth century, depended for exports were corn and woollen manufactures. Especially during the latter half of the century did these commodities come into the foreground in the statutes of the country. The exportation of wool was prohibited, and several regulations were made, enforcing the use of woollen articles. Laws were passed prohibiting the importation of foreign goods that competed with the English-made product. Nevertheless, along with these measures to encourage woollen manufactures an export duty levied at the time of the Restoration remained in force until 1700 .

The agricultural interests were much stronger than the woollen. In 1660 , corn was subject to an export duty, and could be exported only when the prices were below certain fixed rates. ${ }^{x}$ Three years later, the limit of prices was raised. During the eighties there was a great outflow of silver and many agitated for the prohibition of

$$
\text { ' } 12 \text { Chas. II, c. } 4 .
$$


the exportation of the precious metals. In I690, three different measures for that purpose were proposed in the House of Commons. As a result great activity sprang up among the East India merchants, who were compelled to send silver to India for the purchase of their goods. They claimed that it was folly to prohibit the export of gold and silver, and that wealth in these metals could be maintained only by fostering trade and industry, so that a favorable balance could be secured. Along with the agitation over the prohibition, came greater attention to exportation. Since corn was a great staple of export, we should naturally expect that steps would be taken to increase the production of it. In place of abolishing the export duties on grain, a bounty on its exportation was granted when the prices were at or under certain figures. ${ }^{x}$ Henceforth corn was to be produced as a commodity for export, and it was contended that agriculture and industry should be encouraged, so that England might be made to export as much as possible.

In 1707 , bounties were given on malt and oatmeal." As a consequence, agriculture flourished; for since the farmers were always assured of good prices, they greatly increased the crop acreage. The exports of all kinds of corn increased from 102,255 quarters in 1697 to 654,471 in 1722 . The crop failures of 1727,1728 and 1729 caused the exports to drop to 174,450 quarters in 1729 , but the return of bountiful harvests raised them to 719,137 in 1733. The poor crop of 1735 and 1736 caused another drop, but in 1738 the high figure of 923,459 quarters was reached. The imports varied from one quarter in 1722 , to 373,655 in 1729 . The bounties paid on the export of all kinds of corn ranged from $£ \mathrm{I} 8,580$

'i W. and M., c. 12 . 
in 1741 , to $£ 177,737$ in $1738 .^{1}$ The bounties were one of the chief reasons for the increase in corn production, and the exportation to the continent.

Walpole did not alter the bounties on corn, but made two important changes to check certain frauds that had arisen in measuring the grain and malt exported. According to the act for encouraging the exportation of corn in 1689 , the amount of corn exported was ascertained by the sworn certificate of the exporter. The number of quarters was greatly exaggerated, and in order to check this abuse, Walpole, in 1729 , enacted that the proper officers of the customs should be empowered to measure all corn and grain upon which there was an allowance payable for exportation. The maltsters had been defrauding the revenue by steeping, wetting and sprouting the malt for export, thereby considerably increasing the measurement. To remedy this abuse, it was enacted that after the twenty-fourth of June, I730, there should be paid to maltsters, for every twenty quarters of grain, after the same should be dried and made into malt for exportation, a bounty equal to that on thirty quarters, and no more, even though the maltsters by steeping, wetting and watering the twenty quarters should increase

${ }^{1}$ Bounties paid on exportation of corn from Great Britain.

$\begin{array}{lrrr}1721 & 664,375 & 1732 & 660,760 \\ 1722 & 91,304 & 1733 & 114,654 \\ 1723 & 86,558 & 1734 & 171,000 \\ 1724 & 77,935 & 1735 & 100,038 \\ 1725 & 107,524 & 1736 & 50,562 \\ 1726 & 83,308 & 1737 & 102,511 \\ 1727 & 48,756 & 1738 & 177,737 \\ 1728 & 28,296 & 1739 & 145,702 \\ 1729 & 18,945 & 1740 & 39,366 \\ 1730 & 40,590 & 1741 & 18,580 \\ 1731 & 58,492 & & \end{array}$

Thornton, H.. Historical Summary of Corn Laws, I84I, p. 42. 
them to more than thirty. These two changes were badly needed, and to a certain extent put an end to the prevalent methods of defrauding the revenue.

After the introduction of the bounty on grain it was some time before attention was given to assisting manufactures in order to increase exportation. Allowances were given, in 1699 and 1705 , on the exportation of refined sugar manufactured from raw sugar grown in the British colonies. ${ }^{x}$ Bounties were granted in $17 \mathrm{I} 3$ on the exportation of British-made sailcloth, ${ }^{2}$ but it was Walpole's administration that marked the beginning of the policy to increase the exportation of manufactured commodities by liberally assisting the manufacturer, through abolishing duties, granting drawbacks and giving bounties.

This policy is clearly outlined in the preamble of an act to assist the silk manufacturers, where it is stated that the wealth and prosperity of the kingdom depend to a large extent on the improvement of its manufactures and the profitable trade carried on by their exportation, which trade should by all proper means be encouraged for the more comfortable support and maintenance of great numbers of people and for the enlargement of the commerce of Great Britain. The attention that had previously centered about agriculture as the means of assuring a favorable balance now turned to manufactures. The act further declares that the manufacture of silk goods has been greatly developed, and that the exportation of them would be increased if some assistance were given to the silk manufacturers. It was accordingly enacted that on and after the twenty-fifth of March, I722, for the

${ }^{1} 9$ and ro Wm. III, c. $23 ; 2$ and 3 Anne, c. 9.

${ }^{2} 12$ Anne, c. I6. 
space of three years, certain allowances should be paid to exporters of silk commodities manufactured in Great Britain. ${ }^{2}$ From this time we find many industries receiving assistance, whereas before it was corn and wool that monopolized the attention of Parliament.

England, being a great ship-owning nation, consumed many thousand yards of sail-cloth in equipping her sailing fleets. All sailcloth was originally imported from France, but in 1590 , it began to be manufactured in England. During the time of the persecution of the French Protestants, thousands of skilled workmen sought refuge in England, among whom were many skilled in sail-making. In order to encourage them in their new home, it was enacted in 1696 that all British-made sail-cloth should be exported free of duty. A bounty of one penny per ell on all British-made sails exported was granted in I $713 .^{2}$ Still greater assistance was given in I73I, when it was enacted that all import duties on rough and undressed flax should be abolished; that all drawbacks on the reexportation of foreign sail-cloths should be repealed; that an additional bounty of one penny per ell should be granted on all British made sail-cloth exported. ${ }^{3}$ The bounty was not withdrawn until 1797 .

The import duty on saltpeter was very high, and proved

${ }^{1} 8$ Geo. I, c. 15. Ribbons and stuffs made in Great Britain of silk only and exported, 3s. per lb. avoir.; ribbons and silks made in Great Britain of silk mixed with gold or silver and exported, $4 \mathrm{~s}$. per lb. avoir.; silk stockings, gloves, fringes, laces and sewing silk, made in Great Britain and exported, Is. 3d. per lb. avoir.; grogram yarn, made in Great Britain and exported, 8d. per lb. avoir.; all stuffs made in Great Britain mixed with ingle or cotton, Is. per lb. avoir.; all silks made in Great Britain or silk and worsted and exported, 6d. per lb. avoir.

'I2 Anne, c. I6; continued by 5 Geo. I, c. 25, ro Geo. I, c. 17; 8 Geo. II, c. 18 .

4 Geo. II, c. 27. 
a heavy burden to the manufacturer of gunpowder. In order to encourage the production of this commodity, it was enacted, in I73I, that a bounty of five shillings a barrel be allowed on all British gunpowder exported as morchandise. ${ }^{x}$ The preamble to the act states that the wealth and prosperity of the kingdom depend greatly upon the improvement of its manufactures and the profitable trade carried on by their exportation, which trade should by all possible means be encouraged for the increase of the commerce of Great Britain. It is obvious that the object sought was the increase of national wealth, and that this was to be obtained through the channel of trade.

Although encouragement had been given to those engaged in the whale fisheries, it did not prove sufficient to improve the industry. The South Sea Company, in I724, decided to add whale fishing to their many enterprises, but the adventure proved a failure. Immediatcly before the company determined to abandon the enterprise, the directors applied to Parliament for a bounty on the products of the fishery, and although it could not then be secured, a bounty was granted in the following year. It is stated in the preamble that great quantities of whale-oil and whale-fins were, at a great expense, bought of foreigners, and annually imported into the country, and that to put a stop to this, care should be taken to increase the English production of these commodities. It was enacted that a bounty of twenty shillings per ton measurement be paid on the return of every ship of two hundred tons and upwards, employed by Englishmen in the whale fisheries to Green-

${ }^{1} 4$ Geo. II, c. 29, enacted for seven years, and continued for a further term of seven years by ro Geo. II, c. 27 . 
land and Davis' Straits, and licensed according to regulations laid down by the act. ${ }^{x}$ The greater frugality of the Dutch still enabled them to undersell the English in their own market, in whale-oil and whale-fins, and, consequently, further encouragement was given in $\mathrm{I} 740$ by an additional bounty of ten shillings per ton. It was also enacted that no Greenland sailors or fishermen should be impressed from the whaling service. ${ }^{2}$ In this case, in place of increasing exportation, the purpose of the bounty was to increase home production, in order to diminish the importation of the foreign commodities.

The production of raw sugar had increased to such an extent in the British plantations that in 1670 the planters were able to undersell the Portuguese in the English market. The refining of raw sugar, first introduced into England about $1659,^{3}$ had become quite an inclustry. In order to increase its output, Parliament in 1698 granted a bounty of three shillings per hundredweight upon the exportation of all British sugar refined from the raw product of the English plantations. ${ }^{4}$ Six years later an additional bounty of one shilling was granted..$^{\circ}$ France was slowly becoming England's rival in the sugar market, and so strong had the competition become that in the early thirties it was feared that England could not keep up her rate of export, let alone increase it. Accordingly in 1733 it was deemed necessary to grant an additional bounty of two shillings per hundredweight, ${ }^{6}$

${ }^{1} 6 \mathrm{Geo}$. II, c. 33, it remained in force until 1740 , continued by 13 Geo. II, c. 28 .

${ }^{2}$ I $_{3}$ Geo. II, c. 28.

"MacPherson, Annals of Commerce, vol. ii, p. 478 .

49 and ro Wm. III, c. 23.

${ }^{5} 2$ and 3 Anne, c. 9.

' 6 Geo. II, c. I3, granted for five years, continued by II Geo. II, c. 18 , for seven years. 
making a total of six shillings. This proved a great boon in developing England's sugar industry and in increasing her exportation of the refined product.

According to the bounty act of 1689 an allowance of two and a half shillings per quarter was allowed the exporter of barley or malt when barley sold at twenty-four shillings a quarter or under. Twelve quarters of barley were used to make a tun of spirits, but it was uncertain how much of the barley was made into malt. In order to prevent any dispute that might arise it was enacted that for every tun of spirits drawn from barley, malt or other corn, and exported, there should be paid to the exporter, when barley was at twenty-four shillings or under, a bounty of one pound ten shillings. To encourage the exportation of spirits drawn from wheat it was further enacted that for every tun of spirits drawn from that grain, without any mixture of any other materials, there should be allowed on its exportation a bounty of four pounds eighteen shillings. ${ }^{\mathrm{r}}$

Bounties were used by Walpole to increase exportation, by encouraging the production of certain commodities. In every case, the chief point emphasized was the increase of British commerce and national wealth. As yet, there

I was no tlought of the infant industry argument, but fullfledged industries were chosen for encouragement. The manufactures selected were those which had reached a certain degree of perfection, and which with a little assistance could, therefore, greatly increase their production. The whole policy was mercantilistic, and the sole aim was to obtain a favorable balance of trade.

Drawbacks were originally granted for the purpose of encouraging trade. As the foreigners paid their freight 
in coin, the people believed that the country would gain in gold and silver. The repayment of the duty rarely amounted to the original amount paid, so that the country made an extra gain. This was simply carrying out the fundamental iclea of the time, that treasure was obtained by a necessity of commerce. Thomas Mun, attracted by Spain's failure to keep her incoming treasure in spite of her laws prolubiting the export of the precious metals, resolved to make a careful study of the means of acquiring national wealth. The result of his investigation was published in a pamphlet entitled England's Treasure by Foreign Trade, in which he lays down the golden rule that England should sell more to strangers than she consumed of theirs in value. This became the fundamental basis of the policy, not only of England, ' but of all other commercial countries. The problem that confronted the statesman was how to increase exports and to decrease imports. The statesman had to look to the producer, either in agriculture or in manufacture, as the great source of national wealth. With the accession of William and Mary we find Mun's maxim becoming the open and avowed policy of England. In the same year that a bounty was given on the exportation of English-grown corn, a drawback of the excise was granted on the exportation of beer, ale, mum, cider and perry made in Great Britain." This is the first instance of a drawback on the exportation of home-produced commodities.

During the reigns of William and Anne many duties and excises were imposed. On the re-exportation of foreign commodities, with but few exceptions drawbacks were paid to the exporter. When home-made excised 
articles were exported the excise was invariably repaid. Thus, when Walpole took office, drawbacks were used either to foster trade or to increase the exportation of English-made commodities. During his administration the same policy toward drawbacks was pursued with the exception that on a few occasions assistance was given to the English producer by abolishing them.

Walpole, soon after coming into power, commenced his war against fraud and smuggling. In I 723 he determined to check the frauds in the drawbacks on tobacco. The regulations governing its exportation were not only made more strict, but it was enacted that in the case of tobacco exported in casks of at least three hundred pounds, the whole duty should be repaid; that no drawback should be allowed for tobacco exported in packages unless it were cut or rolled, or for the exportation of tobacco stalks or stems." Certain frauds had arisen in the trade with the Isle of Man. The same drawbacks as to a foreign country had been allowed on the exportation of commodities to that island. It was discovered that great sums of money were fraudulently paid as drawbacks for merchandise and tobacco shipped to the island, the inajor part of the goods being relanded on the coast of Great Britain or Ireland, and the customs being therefore leirauded of large sums of money. To remedy this state of affairs it was enacted that no drawback should be allowed for any tobacco or merchandise exported after the twenty-fourth day of July, 1726 , from Great Britian or Ireland to the Isle of Man."

By an act of 1731 , the drawback on the re-exportation of foreign sails was abolished. In another section of the same act it was declared that foreign unwrought hemp

'9 Geo. I. c. 2 r. ${ }^{x}$ I2 Geo. I, c. 28. 
re-exported drew back part of the duties payabie on the importation thereof to the great discouragement of the English manufacturer of cordage. To overcome this grievance, it was enacted that after the twenty-fourth of June, I73I, there should not be allowed any drawbacks on the re-exportation of unwrought hemp to any of the British dominions in America.'

In order to satisfy the complaining paper manufacturers, the drawbacks on the re-exportation of foreign paper were, after the twenty-fourth of June, I737, abolished. ${ }^{2}$ During the same session of Parliament, the English oyster industry was encouraged by the abolition of the drawbacks on the re-exportation of imported oysters. ${ }^{3}$ Where drawbacks had previously been allowed with a view to encouraging trade, they were now abolished to aid English industry. In every case it was not the consumer but the producer that was considered.

1 Prior to the Commonwealth, the attitude of England toward her colonies was a generous one. In order to strike a blow at the frugal Dutch trader, Cromwell issued his famous Navigation Ordinance, which proved to be the beginning of a policy of colonial regulation and restriction. The Navigation Act of 1660 not only continued the commercial restrictions, but in order to benefit the English trader confined certain colonial commodities to the market of the mother country. During the later years of the Stuarts, many laws were passed that imposed still greater restrictions, and carried out the then established maxim, that the colonists existed only for the benefit of the mother country.

With the accession of William of Orange and the acceptance of Mun's balance-of-trade theory a more rigid

${ }^{1} 4$ Geo. II, c. 27.

" Io Geo. II, c. 27.

s io Geo. II, c. 30. 
colonial policy was adopted. The trading and manufacturing interests gradually became more powerful, and exerted considerable influence in dictating England's policy toward her colonies. These were looked upon as the producers of the raw material which the industry of England should work up, and were regarded rather as foreign plantations than as settlements of kith and kin. It was, therefore, not so much the interests of the colonists that guided England in her colonial policy as her jealous fear of their possible interference with her own. Although the colonies were not allowed to compete or fin any way to interfere with the English manufacturer, yet they were encouraged by bounties and preferential treatment to produce the raw materials that were needed by the mother country. The policy throughout was to keep the colonies entirely dependent upon and subordinate to England. They were to exist to foster the trade and industry of the mother country in order that she might acquire national wealth and power.

During almost the entire administration of Walpole the 'Duke of Newcastle was Secretary of State. The Duke was a man whom all historians ridicule on account of his inattention to the colonies and his lack of knowledge of colonial affairs. We should naturally expect the colonies to be left to themselves, and yet England showed considerable activity in her colonial policy. On the opening of Parliament, October the nineteenth, 1721 , the King in his address paid particular attention to the supply of naval stores. The plantations in America abounded with most of the proper materials for this essential part of of England's trade and maritime strength. If by encouragement the colonies could be induced to produce those naval stores which were then imported from foreign countries, it would not only greatly increase the riches 
and power of the nation, but by employing the colonies in this useful and advantageous service would divert them from carrying on manufactures which interfered with those of England. Here was shown the aim of the colonial policy of the period. The colonies were to be encouraged to produce those raw materials that might benefit England's trade and manufactures. They were not to manufacture their own materials, but their markets were to be reserved for English goods.

The address of the King was followed by an act further to encourage the importation of naval stores. The bounty of six pounds per ton on colony-grown hemp, which was to expire the first of January, I725,' was continued for a further term of sixteen years. As an additional encouragement all hemp, wood, timber and lumber imported from America should after the twenty-fourth of June, I722, be duty free. Special regulations were prescribed for the production of tar, and as there was a great demand for masts and spars for the English navy and shipping fleets it was ordered that no white pine trees growing without the limits of any township in America should, after the twenty-first of September, 1722 , be cut, felled or destroyed withou a royal license. Although this act assisted the colonies by abolishing import duties on some of their forest products, yet the policy of regulation was not wanting. ${ }^{3}$

The manufacture of copper in England had reached,

13 and 4 Anne, c. I0; I2 Anne, sess. I, c. 9 .

28 Geo. I, c. 12 .

The bounty on imported naval stores: water-rotted hemp, and so. forth, per ton of $20 \mathrm{cwt}$., $£ 6$; masts, yards and bowsprits, per ton, $£ \mathrm{I}$; tar, clean and so forth, fit for making cordage, per ton containing 8 bbls., $\mathscr{L}^{2} 4 \mathrm{~s}$; tar made from trees according to certain directions, $\mathscr{L}_{4}$; pitch, per ton of $20 \mathrm{cwt} ., £ \mathrm{r}$; turpentine, per ton of $20 \mathrm{cwt} . \not \mathrm{I}$ ros. 
even as early as I7I3, a marked degree of perfection. In that year, the drawback on the exportation of copper bars imported from abroad expired, and as England manufactured a sufficient amount for home and for her plantations, it was enacted that no drawback be allowed on the exportation of any copper but such as should be imported from the East Indies and the coast of Barbary.' The production of copper ore had greatly increased in the colonies, and it was being exported to foreign markets. The English manufacturer wanted the colonial ore, and the trader desired the trade. These two interests succeeded in 1722 in having it enacted that copper ore, the product of British plantations, should be treated as an enumerated article, and be subject to the same regulations." During the same session of Parliament, beaver skins were added to the enumerated list. ${ }^{3}$

Sir William Keith, writing in 1726 , states that all advantageous projects or commercial enterprises in any colony, which were prejudicial to the interests of the mother country, must be understood to be illegal and the practice of them unwarrantable, because they contradicted the end for which the colonies existed. ${ }^{4}$ Here is clearly stated the policy of the time. To encourage the fishing industry, salt, by an act of 1727 , was allowed to be imported from any part of Europe directly to Pennsylvania.5 The preamble states that this would benefit the trade of Great Britain and assist the colonists by enabling them to pur-

'I2 Anne, sess. I, c. I8, allowed for 14 years, continued by 13 Geo. I, c. 27 for 14 years.

${ }^{2} 8 \mathrm{Geo}$. I, c. 18 , continued by various acts to 1743 .

38 Geo. I, c. 15.

- Paper in Record Office, quoted by H. E. Egerton, A Shurt History of British Colonial Policy', p. Ig6.

${ }^{\circ}$ I3 Geo. I, c. 5. 
chase more of the-British manufactures than they then did. Three years later, the same privilege was extended to the province of New York." The purpose was to increase English trade and to give the English manufacturers a large market for their goods.

The colonists. in order to evade the law governing the cutting of white pine trees, converted into townships great tracts covered with valuable timber. This enabled them to cut large quantities of choice timber. The howe government, to protect the pine forests, enacted that after I 729 no person in any colony in America should cut or fell any white pine trees except only such as were the property of private persons. The bounties, which owing to the several frauds that had arisen had been allowed to expire, were by this act revived. Several regulations were made to govern production and to guard against fraud in connection with each of the articles upon which a bounty had been given. ${ }^{2}$.

In 1704 rice, a staple product of the colonies, was made an enumerated article. ${ }^{3}$ This proved a great disadvantage in competing with foreign rice in the southern markets of Europe. Since rice was sent to England, it did not benefit the English manufacturer, and he was therefore indifferent. The trading interests thought that if rice were allowed to be carried directly from America to Southern Europe it would encourage the colonial production of the article, and that the increased shipping would more than offset the loss caused by not taking it first to England. Carolina was the province specially adapted for the growing of rice. It was accordingly

${ }^{1} 3$ Geo. II, c. I2.

22 Geo. II, c. 35 ; bounties on masts, spars and so forth were given to importations from Scotland.

" 3 and 4 Anne, c. 5. 
enacted that after the twenty-ninth of September, I730, rice might be carried from that province directly to any part of Europe south of Cape Finisterre, in ships built and navigated according to law. From all other provinces it was still to be an enumerated article. In I732, the colony of Georgia was founded. Hitherto, American colonies had been planted for the benefit of the undertaker, but Georgia was started purely for patriotic and charitable purposes. It was the first time that the state aided immigration to relieve the distress at home. When the rice act was continued, in 1735 , the privilege of Carolina was therefore extended to Georgia, ${ }^{2}$ because it was thought that this would encourage the production of this staple article in the new colony.

It was due to the influence of the hat manufacturers that beaver skins were made enumerated articles. They now became jealous of the hat industry which had reached some perfection in the colonies. In I732, it was declared that the colonies were not only manufacturing for themselves great quantities of hats, which had originally been supplied from England, but that they were exporting them to foreign countries and competing with the mother country. To put a stop to this grievance, it was ordered that after the twenty-ninth of September, 1732, no hats be exported from a British plantation, either to foreign countries or to other colonies. The British manufacturers also complained that hats were made in the colonies by men who had not served their seven years' apprenticeship. This, they said, cheapened the manufacture and lowered the quality of the hats. To remedy this grievance, it was further enacted that none

' 3 Geo. II, c. 28 , granted for five years.

$28 \mathrm{Geo}$. II, c. I9, continued to 1742 . 
were to make felts or hats but such as had served the seven years' apprenticeship, and that no maker of felt or hats should have more than two apprentices at one time, or take any apprentice for any less time than seven years. The regulations were doubtless harsh, but as the act was not very strictly enforced, and as an extended system of smuggling was carried on in the colonies, it is doubtful whether many of the colonists really suffered as a result of it. ${ }^{x}$

Great quantities of coffee were used in England, which were imported for the most part from foreign countries. The production of coffee in Jamaica had become quite an industry, but the planters could not compete with those of the Dutch and French islands. To encourage the production of the bean, it was ordered that after the twenty-fifth of March, I735, all coffee, the growth of any British plantation in America should, in lieu of the inland duty of two shillings per pound, pay one shilling sixpence. $^{2}$ The aim was to increase the production of the colonial article in order to decrease the importation of the foreign.

The British North American colonies had developed quite a considerable trade with the French, Dutch and Danish sugar-producing islands. They took rum, sugar and molasses in exchange for horses, lumber and provisions. This angered the British Southern colonies, and petitions were sent to the home government complaining that they were suffering from the competition of the foreign sugar colonies and praying for some aid, in default of which their industry would suffer. In answer, Parliament in I733 said that the sugar colonies

${ }^{1} 5$ Geo. II, c. 22.

${ }^{2} 5$ Geo. II, c. 24 , remained in force for four years, and was continued by II Geo. II, c. I 8 for seven years more. 
in America were of the greatest consequence to the trade of England, and that the planters were unable to carry on their sugar trade on an equal footing with the foreign sugar colonies without being given some advantage. It was accordingly enacted that after the twenty-fifth of December, I733, nine pence per gallon should be paid on rum and spirits manufactured in the foreign colonies on importation to the British plantations; that six pence per gallon should be paid on all molasses and syrups, and five shillings per hundredweight on all sugars, if made in foreign colonies and imported into the British plantations. It was further enacted that no sugar, syrup or molasses, of the growth of any colonies in America, nor any rum or spirits of America, except the growth or manufacture of English colonies, should be imported into Ireland unless first shipped to Great Britain in ships built and navigated according to law; that all duties paid for sugar imported from the British colonies should, after the twenty-fourth of June, I733, be repaid on exportation. ${ }^{3}$ The keen competition, especially with the French, in the foreign sugar market had been felt by the English trader. He saw that unless some change were to take place he would lose a lucrative trade. With sugar an enumerated article, and a duty on importation, he was placed at a great disadvantage in competing with the French. Thus it was the trading interests that sought the granting of drawbacks on exportation, and it was the trader whom they were designed to please; the benefit to the planter was a matter of only secondary consideration. A drawback would place the English trader on a more nearly equal footing with his

${ }^{1} 6 \mathrm{Geo}$. II, c. 13 , in force for five years, continued for seven years by II Geo. II, c. 18. 
French rival, for England looked upon colonial interests as only subservient to her own.

The sugar industry in the British colonies had developed into a very important one. In 1734, the production had increased to $\mathrm{I}, 200,000$ hundredweight. ${ }^{2}$ The French, Dutch and Danish West Indies were strongly competing with the British in the European markets. At the same time, jealousy had sprung up between the Southern and Northern colonies, because the latter took the products of the foreign sugar plantations in exchange for their provisions, lumber and horses. The sugar planters, through their trading interests, exerted considerable influence on the home government, and it was through that influence that they succeeded in taking revenge on their northern countrymen. The levying of the duties was thus simply the result of a petty jealousy that had arisen between the sister colonies.

The act was considered by the Northern colonies as a cruel grievance. If it had been strictly enforced it would undoubtedly have ruined a very prosperous trade. The people felt that it was passed by the home government simply to please the Southern sugar planters, without a consideration of the result. An American writer said later in speaking of the act that it did not increase the royal revenue, that it did not bring any real advantage to the mother country, and that it had been more beneficial to British sugar colonies, at whose instance it was passed. Many great disadvantages, as well as corrupt and scandalous practices, had followed from it in all the English colonies. The merchants, unwilling to quit trade which was, in a great measure, the foundation of their whole circle of commerce, had gone into illicit methods to en-

${ }^{1}$ Report of Commissioners of Trade and Plantations quoted in Anderson, op. cit., vol. iii, p. 466. 
able them still to carry it on; while the custom-house officers had made a lucrative job in shutting their eyes, or at least, in opening them no further than their own private interests required. ${ }^{\mathrm{r}}$ The act itself clearly demonstrates the spirit in which colonial affairs were treated. As long as the mother country was not concerned, it was immaterial what the result of any act would be on the colonies concerned. This act was, thus a very decided step in that series of commercial legislation which gradually alienated the colonies from the mother land, ${ }^{2}$ for such commercial oppression tended to make the colonists look upon England as a foreign country rather than as a parent.

The French had in 1726 and 1727 granted the privilege of carrying sugar directly from the place of growth to European markets without first landing at a French port. They were vigorously conducting the sugar trade, and by I739 had about driven the English out of the markets of Southern Europe. ${ }^{3}$ Things had come to such a pass that England had to make some concession, or else lose her share of the sugar trade of Europe. The trading interests were deeply interested, but although they had a powerful influence, yet in I 739 only a partial victory was won. The trader was granted the privilege of taking sugar, produced in English plantations, directly from the place of growth to any port in Europe south of Cape Finisterre. ${ }^{4}$ It was the last thread by which England hoped to retain some of the sugar trade of Southern Europe. Thus, we see, it was not for the love of the colonies, but for self-preservation, that the act was passed.

'Essay on the Trade of the Northern Colonies, printed at Philadelphia and reprinted at London, I764, p. 20.

${ }^{2}$ Vide Kahm's Travels, Pinkerton's Travels, vol. xiii.

${ }^{3}$ Present State of British and French Sugar Colonies, 1740, p. I5.

'12 Geo. II, c. 30. 
Throughout the Walpolian administration we have learned that the two great interests that influenced the colonial policy were those of the trader and the manufacturer. They worked together hand in hand, and the government was eager to gain their support. It was to their interest to increase trade, and this the people thought would increase the national wealth and power. Though Newcastle paid little heed to the state of affairs in the colonies, the traders and manufacturers were always on the alert to protect their own interests. If more attention had been paid to colonial conditions the sugar duties would never have been passed in 1733 . Everything was done to promote the trading and manufacturing interests, and the home government paid little heed to the effect of any act upon the colonies. Many acts, on their face, appeared to be designed to promote the interest of the colonies, but this was only a blind. Their main purpose was to aid greater interests at home. Many severe commercial regulations were added to the existing large number, and if they had been enforced, there is not much doubt that the American Revolution would have occurred long before it actually did. The main salutary effect of Newcastle's lethargy was the laxity given to the enforcement of English laws, and it was owing to this that the colonists had nearly ceased their murmurings. By commercial and industrial regulations attempts were made to restrict the colonies to the production of raw materials which England was to work up, to discourage any manufactures that would in any way compete with the mother country, and to confine their markets to the English trader and manufacturer. To a certain extent it was a policy of servitude, and one that no freedom-loving people could long endure even from their own kith and kin. 


\section{CHAPTER VI}

THE INDUSTRIAL POLICY

The Revolution was not only the beginning of a new era in representative government, but it also marked a new phase in economic life, and a new epoch in England's economic policy. The chief cause of this was the discovery of the fallacies of the old bullionist idea of wealth, and the adoption of the mercantilistic theory. In the future, trade was to be gauged by its reaction on native industry. It became the policy of the government to watch this reaction with a jealous eye, and to discourage all commerce that was unfavorable. The producer became the all-important person, and it was through him that the country was to secure the means of increasing national wealth and power. The government had to assist him to produce as cheaply as possible, so that great quantities of English-made goods could be sold in foreign markets, and at the same time care had to be taken that as few as possible of foreign commodities were consumed at home. It was an imitation of the policy of the great French minister, Colbert, the great difference being that the restrictions and regulations were made by parliamentary legislation, and not by royal mandates.

The revocation of the Edict of Nantes, in October, I685, was in some respects one of the most important events in the development of English manufactures. Under the careful tutelage of Colbert, the French artisans had reached a perfection in skill that was unrivaled 166 
in Europe. England could not compete with France in quality and cheapness of commodities. After the death of Colbert, Louis XIV began to fear the strength of the Protestants and commenced a policy of persecution. With the severing of the last thread of protection in 1685 , thousands of French Protestants sought refuge in England. Among these were some of the most skilled workmen in the country. What France lost, England gained. It was only a short time before England commenced to manufacture goods as cheaply, and of as good a quality as her French rival, and to compete successfully with her in the markets of Europe.

Bounties, drawbacks, repeal of duties, regulation of colonial industry and commerce were used to foster the growth of home industry. Laws were passed, enforcing consumption of English-made goods, and treaties were made, extending the markets for English commodities. Labor and wages were carefully regulated by statutes, the first of which were passed in the reign of Queen Elizabeth. Guilds, with their by-laws, protected their members and regulated the quality of their wares. The state by numerous regulations guaranteed the genuineness of commodities, regarding it as its duty to do so, rather than to leave it to the consumer to discover their qualities. Such, at the beginning of the administration of Walpole, was the policy of govermental regulation and supervision.

Walpole believed that the prosperity of a nation depended upon its industry, and that the government should give every possible encouragement to the producer. In accordance with this belief, he introduced a number of reforms in his first Parliament. Since England gave employment to many people in the contiguous fishing grounds, the fishing industry was encouraged by the abolition of all duties on salt used in the curing 
of herring for exportation. ${ }^{x}$ Furthermore, as American hemp was badly needed by English rope and sail makers, not only was the bounty on hemp continued, but the duty on its importation was repealed. ${ }^{2}$ Again, the British forests could not supply the demand for lumber and timber, and accordingly in order to assist the manufacturers all import duties on these colonial products were abolished. ${ }^{3}$ The French were very strong competitors of the English silk and woolen manufacturers in foreign markets. Since the English felt themselves at a considerable disadvantage in being burdened with import duties on raw products, a bounty was given on Englishmade silk products on exportation, in order to remedy this grievance, and certain import duties on drugs used in dyeing were abolished. ${ }^{4}$ In order to place the English producers on a more equal footing with their foreign rivals, the export duties on English-made commodities were, with but few exceptions, repealed. The hat manufacturers contended that the American furs were shipped abroad to the great advantage of their foreign competitors. To remedy this, it was enacted that all furs should be enumerated commodities. ${ }^{5}$ The copper manufacturers occupied quite a prominent place, and were ever jealous of any advantage that might be given to the foreigner. Copper had been discovered a few years before in the colony of New York, and complaints were made that it was being sent abroad. To put an end to this grievance it was made an enumerated article. ${ }^{6}$ Exporters of butter from the city of York complained not only of

'Red, 8 Geo. I, c. 4; white, 8 Geo. I, c. 16.

$38 \mathrm{Geo}$. I, c. I2.

'8 Geo. I, c. 12.

48 Geo. I, c. I5; also rags used in manufacturing were allowed to be imported free of duty.

${ }^{3} 8$ Geo. I, c. I5.

${ }^{6} 8$ Geo. I, c. 18. 
the poor quality of the commodity, but also of a shortage in weight. It was enacted that all butter sold in the city should be weighed, tasted, and sealed at the market, at a fee of one-half penny a firkin. ${ }^{x}$

The strict government surveillance over manufacturing is seen in two acts of $I 724$ and $I 725$. In the former, minute regulations were made to govern the breadth, length, and fineness of rock serges manufactured in Scotland. The magistrates of the head boroughs of every shire were to have made a stamp or stamps, and to appoint one or more stamp masters to inspect all the said serges. The sealing fee for each piece of sixty-three yards was to be one Scottish shilling, and serges not sealed and stamped were to be forfeited. ${ }^{2}$ The later act governed the manufacture of broadcloth in the West Riding of York. It was enacted that the breadth of the broadclotin should be five quarters and a half, and that the half cloth, fully wet, should not exceed twentyfour, nor the long, forty-eight yards in length; that the penalty of clothiers should be twenty shillings for a difference of every inch in breadth and of every half-yard in length; that the broadcloth should be measured at the fulling mill, and the millman affix a seal of lead; and that every clothier should, at the time he made the cloth, weave into the head, in distinct letters and words, his name and abode. ${ }^{3}$ These strict regulations raised the standard of the goods, and proved to be a decided advantage to the foreign trade in these commodities.

Attention was drawn to several abuses that had arisen in the making of brick and tile for building purposes. Many brick and tile makers were accused of making the articles under size, and of inferior quality. To remedy

${ }^{1} 8$ Geo. I, c. $27 .{ }^{2}$ Io Geo. I, c. I8. ${ }^{3}$ II Geo. I, c. 24. 
this abuse, it was ordered that the preparation of earth, the burning and the size of bricks and tiles should be according to a prescribed standard. ${ }^{x}$ It is probable that such strict regulations for guaranteeing the proper standard of brick and tile were necessary at that time.

The year 1727 is noted for its laws to prevent abuses and frauds in various manufactures of cloths and linens. Rigid regulations were made governing the length of warping bars and thrums used in mixing with cloths. It was enacted that every maker of goods mixed with wool should give out wool or yarn to the manufacturer by weight of sixteen ounces to the pound, and that no clothier should use ends of yarn or other refuse of cloth in manufactures. For the carrying out of the above regulations, inspectors were to be chosen annually by the general sessions. ${ }^{2}$ In order to guarantee a higher standard of dyed woollens, it was provided that all black baize or woollen goods should be dyed only with woad, madder and indigo; that all woollen goods properly colored should be duly marked and that searchers should be appointed by the company of dyers in London, and by the quarter-sessions elsewhere, to see that the regulations were carried out. ${ }^{3}$ Complaints were made that the manufacturers of linen and hemp goods in Scotland were much injured by lack of regulations governing the same. To remedy this grievance and to raise the standard of these manufactures, it was enacted that no bad hemp or linseed should be imported into Scotland; that no person should import into that country, or offer there for sale, any hemp yarn that was not of standard quality; that all linen cloth should be of a standard length and breadth, and properly bleached; that the king might appoint trustees.

$$
\text { 12 Geo. I, c. 35. '13 Geo. I, c. 23. "'13 Geo. I, c. } 24 .
$$


to oversee the linen and hempen trade, who might choose inspectors or lappers to inspect, measure, and stamp all linen goods before they were offered for sale; and that it should be lawful for the linen manufacturer to weave some known mark in any piece of linen of his manufacture, and that if any person counterfeited it, he should be subject to a fine of one hundred pounds. ${ }^{x}$

The making of sailcloth had reached a marked degree of perfection. The British statesmen were always careful to assist this industry, not only in order to increase the exportation of the commodity, but also in order to better the quality, and to decrease the importation of foreign-made sails. In 173 I the industry was greatly assisted by an act providing that undressed flax should be imported free of duty, that no drawback should be paid on the re-exportation of foreign sailcloth, that the maker should affix his name and abode to every piece manufactured, and that a bounty of one penny per ell should be paid on all British sailcloth exported. ${ }^{2}$ As a rule, it was the well-established industries that received the greatest attention, because with a little assistance they would be able to undersell their foreign competitors and thus increase the exportation of English-made goods.

The jealousy with which the English manufacturer looked upon colonial competition is seen in the enactments of the year I732. There had been considerable smuggling of Irish woollen manufactures from Ireland to Europe, a custom which the English manufacturers declared was to their disadvantage. To prevent the illicit

${ }^{1}$ I3 Geo. I, c. 26.

${ }_{4}^{2}$ Geo. II, c. 27 . By 9 Geo. II, c. 37 , all imported sailcloth should be stamped at point of landing. Every ship built in Great Britain or British plantations should have a complete set of British-made sails; if not, it should be liable to a fine of fifty pounds. 
trade, three ships and eight armed cruisers were ordered to be selected by the admiralty to cruise along the coast of Great Britain and Ireland, with the right to search and seize all vessels having woollen manufactures aboard, without a lawful warrant granting the transportation thereof. ${ }^{x}$ England believed that Ireland should develop only the linen industry, and not compete with her in the woollen manufactures. At this time the American hat industry had reached such a point of perfection that many hats were annually exported to Europe. The English manufacturer strongly opposed this, and succeeded

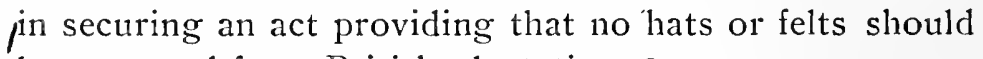
be exported from British plantations. ${ }^{2}$

After the defeat of the excise scheme in 1733 , the interest taken in industrial regulations was slight. In I73 8 an act was passed to better regulate the manufacture of narrow woolen cioths in the West Riding of York. It was provided that the makers of these cloths should set their initials at the head of each piece; that the cloth should be measured while wet at the mill, both by the millman and by the searcher, and that the millman should rivet a seal of lead to one end of each piece and stamp thereon its length and breadth and his own initials, while at the other end the searcher should affix a similar seal, and theretipon stamp his name and the length and breadth of the cloth. ${ }^{3}$ The following year the manufacture of gold and silver wares was regulated. All gold wares should be in fineness not less than twenty-two carats, and silver not less than eleven ounces two pennyweights in every pound troy, and should bear a stamp with the initials of the maker and the fineness. ${ }^{4}$ The act

\footnotetext{
${ }^{1} 5$ Geo. II, c. 2 I.

${ }^{2} 5$ Geo. II, c. 22.

"II Geo. II, c. 28.

4I2 Geo. II, c. 26.
} 
was necessary because large quantities of gold and silver commodities of inferior quality were being sent abroad.

The laborers, having greatly increased in numbers and in skill, were becoming bolder in the assertion of their rights. In I72I, on the master tailors' complaint to Parliament of the journeymen combining to raise wages and reduce the hours of labor, ${ }^{\prime}$ an act was passed restraining the former from giving, and the latter from receiving, wages in excess of a stated maximum. ${ }^{2}$ The men strenuously resisted the law and it remained a dead letter. ${ }^{3}$ The want of fixed wages led to the oppression of the workmen by their masters, and induced the men to combine. $^{4}$ As they became bolder, their combinations increased in numbers, and their greatest strength was seen in the woollen manufactures. The Journal of the Housc of Commons contains evidence of combinations in Devonshire and Somersetshire as early as I7I8.5 It was thought that the practice could be abolished by royal authority, and accordingly, on February the fourth, I7r9, a royal proclamation against combinations was issued. This did not deter the laborers, for the Journals of $1723^{6}$ and $1725^{7}$ contain frequent complaints of the continuation of combinations. Parliament listened to the complaints, and in I 726 passed an act "to prevent

${ }^{1} \mathrm{~S}$. Webb, History of Trade Union, p. 27.

${ }^{2} 7$ Geo. I, sess. I, c. I3.

"W. A. S. Hewins, "The Origin of Trade Unionism," in Economic Review, vol. v, p. 206.

${ }^{4} \mathrm{~L}$. Brentano, On the History and Development of Gilds, p. I04.

${ }^{3}$ Journal of the House of Commons, vol. xviii, p. 715.

'Petitions from Dartmouth and Exeter, February the twenty-fourth, I723, Journal of the House of Commons, vol. $\mathrm{xx}$, pp. 268-269.

${ }^{7}$ Petitions from Taunton, Tiverton, Exeter and Bristol, March the third and the seventh, I725; ibid., pp. $598 \& 602$. 
unlawful combinations of workmen employed in the woollen manufactures and for better payment of wages." * The recital declared that great numbers of weavers and others had lately formed themselves into unlawful clubs and societies, and had entered into combination to regulate the trade and the prices of goods, and to advance wages. They had committed great violences and outrages, and by force protected themselves and their wicked accomplices against law and justice, so that it was necessary that more effectual provisions should be made against such unlawful combinations.

It was enacted that all contracts, covenants, agreements, or by-laws for regulating the price of goods, for advancing wages, or for lessening the usual hours of work, were and shotild be declared to be illegal and void; that any person who knowingly entered into the same in future, or attempted to plit any illegal agreement into execution should, on being convicted thereof before two or more justices of the peace, be committed to hard labor for three months in the house of correction or the county jail, as the justices might determine; that if any weaver should leave his service before the expiration of the term for which he had been hired, or if he failed to finish his work according to agreement, unless for some reasonable cause to be ailowed by two justices of the peace, he should on conviction be committed to hard labor in the house of correction for a period not exceeding three months; that if any weaver willfully destroyed articles or work entrusted to his care, he should pay the owner double the value thereof, or be committed to hard labor for a period not exceeding three months. The act also directed that clothiers should pay their em- 
ployees the full wages agreed upon in money, and if any clothier should pay the wages agreed upon, or any part thereof, in goods or by way of truck or in any other manner, as aforesaid, he was to forfeit ten pounds, onehalf to the informer and the other half to the party aggrieved. Care was taken to protect the masters against assault and violence by the workmen, in that if any person should assault or abuse a master clothier for not complying with the rules or by-laws of any of the illegal combinations, or should write or cause to be written any letter to such master, threatening to burn or destroy any buildings, or to cut down or destroy any of his trees, or to maim or kill any of his cattle, for not conforming to the demands of the workmen, he should on conviction be adjudged guilty of felony, and be transported for a period of seven years.

In February, 1727, the weavers of Wilts and Somerset combined to petition the king to redress their grievances against the master clothiers. A committee of the Privy Council investigated their grievances, and drew up "Articles of Agreement" for the settlement of the matters in dispute. "The Committee admonished the weavers, in the future, to lay their grievances in a regular way before His Majesty, "who would be always ready to grant them relief suitable to the justice of their case;" and warned them that if they attempted to seek relief through combination, the Lords would recommend that the laws be rigorously enforced. ${ }^{2}$ In 1728 , the weavers of Gloucestershire appealed to the justices of the peace, and induced them to fix a liberal scale of wages. ${ }^{3}$ The weavers for a time appealed directly to the House of

'Journals of the House of Commons, vol. xx, p. 747.

${ }^{2}$ Ibid.

'Ibid., vol. xxvii, p. 503. 
Commons, but when their petitions did not receive due recognition, they resorted to combination, as the only means of righting their wrongs.

During this period, the most successful attempt at raising wages by combination was in 1738 . The clothiers in certain towns of Wiltshire had solemnly promised to raise the wages of their workmen one penny a yard, the amount they had demanded. On the day following this agreement the prices were lowered. The weavers openly attacked, and nearly demolished, the house and factory of Mir. Coulthurst, the leading clothier of Meeksham, and then marched to the market-place and demanded a fifty-pound note, signed by all the clothiers of the place. that they would henceforth give fifteen pence a yard for weaving, and one shilling for spooling. This complied with, they demanded and received a bond from four of the members that the agreement be carried out, on pain of forfeiture of one thousand pounds. ${ }^{x}$

With the great development of manufactures, especially in the woollen industry, we thus notice a tendency on the part of the workmen to combine. As they became more skillful, they were raised from servitude to freedom, and evils and oppressions, which they had borne for generations, were now resented and opposed. Wages were higher than they were at the beginning of the century. Manufacturers and statesmen looked askance at this increase as a menace to national wealth, believing that exportation abroad and not consumption at home would bring wealth to the kingdom. It was on exports,

'The difficulties of the weavers may be obtained from an Essay on Riots, published in 1739 and republished in Gentleman's Magazine, I739, vol. ix, pp. 7-I0, replies, pp. I23-I26; Smith, Memoirs of Wool, vol. ii, pp. 78-88; Gentleman's Magazine, vol. viii, p. 658. 
they thought, that the wealth of a nation depended,' and in order to assist exportation, goods must be produced at a low cost. One of the factors of cheap production, the manufacturers believed, was low wages; it should, therefore, be the duty of the magistrates to keep wages as low as possible. The majority of the magistrates shared this belief, so that the workingmen had to fight, not only for an increase, but very often against the lowering, of their wages. Thus they were driven to combination, for only by united strength could they meet the employers. During this period accordingly we notice the beginning of the social chasm that wealth was making between the employer and the workman. With the chasm widening, the wage-earners became more conscious that they formed one great body and that it was necessary to fight in unison in order to obtain relief from the oppressions of the encroaching employer.

A pamphleteer, in $173^{8}$, stated that the chief methods of gaining riches were agriculture, fisheries and manufacture, and of these, manufacture was the most advantageous to a nation. ${ }^{2}$ During this period the public eye was therefore directed to manufacture, where previously agriculture and still earlier trade had monopolized public attention. The goal was in all cases national wealth. The means used were measures to foster industry so as to export more than was imported. Thus we see the reason , for the favorite belief of the time: "It was exportation abroad and not consumption at home that would bring profit to the kingdom." The aim, therefore, of the in-

'Smith, J., op. cit., p. 84.

${ }^{2}$ The Case of the British and the Irish Manufacturer of Linen, Threads and Tapes fairly stated, and all Objections against Encouragement proposed to be given to that Manufacture fully answered. In a letter, 1738 . 
dustrial policy was to encourage the three great occupations, but especially manufactures, so as to increase exportation over importation and secure a favorable balance of trade. It might be asked how far the government succeeded in developing industry. To answer this, let us make a short survey of the important manufactures. The manufacture of woollen goods was the one that was by far the most important. In 1699 the total value of all woollen manufactures was $£ 8,000,000$, ${ }^{1}$ of which $£ 2$,932,292 were exported. ${ }^{2}$ This is very significant, because the total exports of that year amounted to $£ 6,788,166 .{ }^{3}$ The annual value of British woollens exported reached $\mathfrak{E}_{3,384,842}$ in 1722 , and $\mathfrak{f}_{4}, \mathrm{I}_{5} 8,643$ in 1738.4 Judging from these returns, woollen manufactures in England had never been so prosperous, and it was a long time before they again reached so high a pitch of activity. ${ }^{5}$ In 1739 it is stated that more than $1,500,000$ people were employed in the woollen manufacture. ${ }^{6}$ But from 1735 to I740 there were written many pamphlets that deplored the ruinous state of the woollen industry. ${ }^{\text {? }}$

'MacPherson, Annals of Commerce, vol. ii, p. 707.

${ }^{2}$ British Merchant, vol. ii, p. 276; D'Avenant, Report to the Commissioners of Accounts for the year 1712, I'art II, p. 71 .

${ }^{3}$ Ibid., p. 71 .

'Brothers, Wool and Woollen Manufactures of Greal Britain, pp. 128-129; also Smith, J., Memoirs of Wocl, vol. ii, p. 396.

"The annual average value of British woollens exported during six years ending in $1790, \not 3,544,160$. Brothers, op. cit., p. 129.

${ }^{6}$ MacPherson, op. cit., vol. iii, p. 22r.

${ }^{7}$ A. An Argument upon the Woollen Manufacturc of Great Britain, plainly demonstrating that Ireland must speedily be employed therein, as the only means to recover its Dicay and to prevent its Ruin, London, 1735. B. The Golden Fleece; or the Trade Interest and Well-being of Great Britain Considered; with Remarks on the Rise, Progrcss and present Decay of our Woollen Manufacture, etc., 1736. C. The sinking Stat' of the Woollen Extortation and Trade, humbly re- 
After the woollen industry iron manufactures reached the greatest degree of perfection. In 1685 they were greatly benefited by the addition of many skilled French artisans to the ranks of their workmen. As early as I 7 I9 it is stated that two hundred thousand persons were employed in the iron industry. The following year, in a pamphlet on the subject published by Mr. Wood, England's greatest iron producer, it was maintained that the iron industry was next in importance to the woollen, and that England produced about ten thousand tons of iron annually, and imported about twice as much more. ${ }^{2}$ During I737 many petitions were sent to Parliament asking encouragement for importation of iron from America, and stating that England made annually at home about eighteen thousand tons of bar iron, and that this quantity could not be increased on account of the forests being about exhausted. ${ }^{3}$ In a pamphlet published in 1739, it is stated that the manufactures of iron, brass, copper, gold, silver and other metals of late invention, had reached such perfection, and were so generally esteemed abroad, that there was scarcely a retailer in the known world that had not a constant supply of them for the use of his customers. ${ }^{4}$

Presented by the Britisit Woollen Manufacturers lo the Members of l'arliament, 1737. D. An Essay on Riots, 1739. E. Remarks on the Essay on Weaver's Riots, 1739. F. Observations on British Wool, etc. 739. G. A short Account of the State of our Woollen Manufactures from the Peace of Ryswick in 1697 to this Time 1739, their former fiourishing and their present ruinous Condition, 1739. H. The Conscquences of Trade and of the Woollen Trade in particular, 1740.

${ }^{1}$ MacPherson, op. cit., p. 73.

'Ibid, vol. iii, p. I14. The same Mr. Wood afterwards undertook the coining of copper halfpence for Ireland.

"Ibid., vol. iii, p. 214 .

- The late Improvement in Trade, Narigation and Manufactures considered, etc., 1739. 
The silk manufactures also showed great development. The British Merchant, in I72I, states that the silk product amounted to $£_{700,000}$ per annum in value more than it did at the time of the Revolution. ${ }^{\mathrm{I}}$ The year following came the bounties on English-made silk goods exported. By I730, the high quality of the English silks was known throughout Europe. In that year, Mr. Keystler in his Travels through a great Part of Europe says that in Italy itself the silks of English manufacture were most esteemed, and bore a greater price than those of Italy, so that at Naples, when a tradesman recommended his silk stockings, he protested they were of English make. ${ }^{2}$ The improvement continued, and a pamphleteer in 1739 declared that many other manufactures besides the woollen, particularly those of silk, iron and brass, had been immensely increased within the last twenty years. Before that time. England had received all, or almost all, of her wrought silk from Holland and Italy. Now he asserted the case was different, the English not only producing better work than they, but being able to export these goods, besides furnishing their own consumption. ${ }^{3}$

The manufacture of wares of copper, brass, gold and silver occupied a prominent place. According to a pamphlet published in $\mathrm{x} 72 \mathrm{I}$, about thirty thousand people were engaged in manufactures of copper and brass. ${ }^{4}$ By I739, such great skill had been obtained in all four lines of manufacture, and the quality of the goods was so high,

${ }^{1}$ British Merchant, vol. ii, p. 220, edition I72I.

${ }^{2} \mathrm{Mr}$. MacPherson speaks of Mr. Keystler as an author of credit and esteem, Annals, vol. iii, p. I60.

s The tate Improvement in Trade, Navigation and Manufactures considered, etc., 1739.

"Wood, William, The State of the Copper and Brass Manufactures in Great Britain, 1721 . 
that the English wares were known and sought throughout Europe. ${ }^{I}$ There were many other manufactures that had established themselves and were gaining prominence. Parliament had several times encouraged the production of linen and especially of sailcloth. Linen was an Irish and Scotch, rather than an English product. By 1739, the value of the linen manufactures of these two countries had reached an annual total of $£ 700,000$. The cotton industry was another that was being slowly but firmly established. Its development can be clearly seen from an article in the Daily Advertiser of September the fifth, I739, which says that the manufacture of cotton, mixed and plain, had reached so great a perfection within the past twenty years, that England not only made enough for her own consumption, but supplied her colonies and many of the nations of Europe, and that the benefits from this branch were such as to enable the manufacturers of Manchester to lay out about thirty thousand pounds a year, for many years past, in additional buildings. ${ }^{2}$ During the thirties, a decided activity was shown in the manfacture of threads, tapes, paper and many other smaller articles which, with the improvement in the linen industry, a pamphleteer in I739 asserted, considerably lessened their importations from Holland and Germany every year. ${ }^{3}$

During Walpole's administration, many commercial towns made rapid strides in wealth, population and manufactures. London had become the greatest commercial metropolis in the world. Liverpool and Bristol had grown from small towns in I 700 to large bustling

${ }^{1}$ The late Improvement in Trade, Navigation and Manufactures considercd, $c t c ., 1739$.

'This was also copied into the Gentleman's Magazine.

${ }^{3}$ The late Improvement in Trade, Navigation and Nanufactures considered, etc., I739. 
cities and, after London, the great emporiums of England. Manchester, Defoe stated in 1727 , was the center of the cotton industry and had a thriving population of fifty thousand. Birmingham and Sheffield had become noted throughout Europe for their fine hardware and cutlery. Norwich had risen from a small town to a city of many thousand people, and sent forth the finest worsted cloth in Europe. Newcastle-upon-Tyne had become, not only a leading coal emporium, but also a large manufacturing center. Many small manufacturing centers sprang up throughout many parts of England, and the country had never before experienced such a period of prosperity.

The development in agriculture was as notable as in manufactures. The chief articles of production were wool and corn. With the great impetus given to the woollen manufactures, large quantities of wool were needed. A writer in 1739 declared that fully one-third more wool was being produced than twenty years before, and that the chief cause of the increase was the improvement in

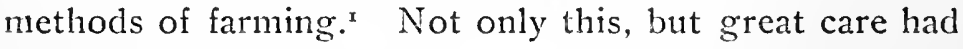
been taken to improve the grade of wool. A woollen manufacturer in 1739 stated that in late years there had been many improvements made in the breeding of sheep, and that there was produced in several of the counties some of the finest combing wool suitable for making all kinds of fine cloths and hose. ${ }^{2}$

With the bounty on the exportation of corn, great strides were made in its production. Corn was grown

'The late Improvement in Trade, Navisation and Manufactures considcrea, ctc., 1739.

"Observations on British Wool and the MIanufacturing of it in this Kiniga'on, etc., by a Woollen Manufacturer of Northamptonshire, 1739. p. 4 . 
as an article of export, and during the first half of the century England was an exporting country. From I 70I to 1721 the excess of exports of corn over imports amounted to a total of $7,206,357$ quarters. During this period there were no bad crops, and only once did the annual excess drop below 200,000 quarters. From I72I to $\mathrm{r} 74 \mathrm{I}$ the excess increased to $9,290,689$ a gain of 2,084,332 quarters. This is all the more remarkable, because during this period England had three years of very poor crops. During 1727 the excess was only 20,460 , while the following year no corn was sent abroad, and I99,205 quarters were imported. The poor crop of I 74 I caused the excess of exports to drop to 25,959 quarters. The most profitable year was 1738 , when the exports exceeded the imports by the unprecedented amount of 923,459 quarters.

The bounties assured the farmers a good price for their grain, and they greatly increased their acreage of corn. New methods of tilling the soil and a new rotation of crops greatly increased the yield per acre. There was no period in this century when the farmers were more eager to improve the methods of farming. Townshend's experiment and the success of turnips and clover led to a new vein of farming. ${ }^{2}$ But it was many years before his system was adopted throughout England. The country was flooded with scores of pamphlets on new and better methods of tilling the soil. With the increase of wealth, buildings on the estates were improved, swamps and fens were drained and more interest was taken in stock-breeding. The

'Thornton, A Compendium of the Laws Governing Corn. London, 1826, p. 33.

${ }^{2}$ Prothero, The Pioneers and Progress of English Farming, p. 46. 
standard of living was greatly increased among all classes. Prothero says that wheaten bread, by 1760 , was no longer a luxury, but was daily used by five-eighths of the agricultural population. From the point of view of agricultural improvement and prosperity, there is not a more interesting period in the eighteenth century than the twenty years during which Walpole was Prime Minister of England.

If wealth and prosperity are any criterions of success, every one must agree that Walpole's industrial, policy was the best that could have been adopted for England at that period. He realized that England needed peace in order to be able to devote her entire energy to her rapidly-developing industries. It was his aim to make England an industrial center, and a shipper of great quantities of manufactured commodities. Competition abroad was becoming extremely keen, and to accomplish his aim many reforms were necessary. The English manufacturer had to be placed as far as possible on an equal footing with his foreign competitors, and if necessary given encouragement. The abolition of duties on importation was somewhat of an innovation, and it was therefore necessary to proceed very slowly. The cloth and fabric manufactures were benefited by the repeal of duties on certain dye-goods. To take the place of Eng(lish lumber, encouragement was given to the importation of the colonial product. The colonies were to be the producers of the raw materials which the mother country was to work up.

It was not only necessary to secure a supply of cheap raw material, but a market had to be provided for the finished goods. The French and Dutch could manufacture as cheaply as the English, if not at a lesser cost, so that the race for the market was very keen. Duties were 
at once abolished on nearly all English-made goods exported. When it was deemed necessary to assist English manufactures still further, bounties were given on exportation. Walpole was always on the alert to extend, by concessions and treaties, the sale of English goods. The colonies were limited to the home market, and were in-t. tended to increase English wealth by aiding the English manufacturer and shipper, while high duties and prohibitions reserved the home market to the home producer. Every possible means was utilized in order to sive the English manufacturer an extensive and profitable market for his goods. Walpole understood that, in order successfully to sell in a strongly competitive market, a high standard of goods was necessary. The manufacturer, being too eager to undersell his rival, would lower the quality of his wares which, in the end, would reflect on other English-made goods. There was only one way to secure goods of a high standard, and that was to regulate their manufacture by governmental supervision.

With the great industrial growth, it is no wonder that Walpole was willing to make great sacrifices, rather than to impecle it by going to war. He was aware that a country, in order successfully to carry on a great war, must have an abundance of national wealth behind it. No doubt he foresaw the impending conflict between the European powers for supremacy, and he believed that when the time should come, England must be ready to carry her arms to victory. As a matter of fact when the struggle came, it was England's manufactures that carried her safely through. Great credit must be given to the fostering care of Walpole, that safely started England on the road leading to the mastery of Europe. 


\section{CHAPTER VII}

Foreign Trade

From the earliest times commerce has been of the greatest importance to England. She did not possess any important mines of gold and silver, and it was to trade that the people early turned as the means of securing the precious metals. Locke observed that trade was a shorter and surer way to riches than any other. ${ }^{x}$ In r757 Postlethwayt said that the greatness of the British nation was not owing to war and conquest, but to trade and commerce. ${ }^{2}$ For nearly a century and a half after the enactment of the Navigation Act, nothing attracted the attention of the statesmen more than foreign trade. Its history is in fact closely connected with that of civilization in general.

Early English commerce was largely dependent upon the will of kings. It was not until the middle of the seventeenth century that it broke away from this bondage. In spite of royal interference, the shipping and foreign trade of England had by the time of Cromwell reached a prominent place. At that period the Dutch were the traders of the world and masters of the seas, and their chief city, Amsterdam, was the world's commercial metropolis. James and Charles I paid but little attention to English trade, and made but slight attempts

'Locke, J., Woiks, vol. ii, p. 8.

'Postlethwayt, M., Universal Dictionary of Trade and Commere, vol. i, p. 542. 
to check the Dutch in their encroachment on English commerce. It was left to Cromwell to strike the fatal blow at Holland as a great trading nation, and to lay the foundation of England's future greatness. The first step was taken by the Ordinance of 1646 , which prohibited the carrying of goods of the American colonies to foreign ports except in English ships. ${ }^{x}$ This was followed in I65I by the first Navigation Act, by which foreign vessels were forbidden to bring into an English port any goods other than those produced in their own countries.

Charles II and his ministers were much opposed to the legislation of the Commonwealth, yet they favored the Navigation Laws of that period. During the first year of Charles' reign, Parliament passed a Navigation Act which was simply a complement of the ordinance of 1646 and of the act of $165 \mathrm{I}^{2}$ This was very favorably received by all merchants, and Sir Josials Child lauded it as "the Maritime Charter of England." In this act we here have clearly defined the so-called colonial system, or the practical application of the theory that colonies exist solely for the benefit of the mother country. In 1662, a second decisive blow was aimed at the Dutch trade in an act that prohibited the importation of a long list of enumeraied articles, whether from Holland, The Netherlands or Germany. This proved the final blow to Dutch commercial supremacy.

The Navigation Act was followed later by an act designed to check the trade with France. Anderson states that the importation of French goods occasioned a great annual loss in the general balance of trade. ${ }^{3}$ The French

'Ordinance quoted in MacPherson, Anilals of Commerce, vol. ii, p. 430. 'Tbid., pp. 484-486.

'Anderson, Annals of Commerce, vol. iii, p. 69. 
ministry from time to time levied duties on English products, and as a result the English foreign trade suffered. Such enmity was aroused against France that in 1678 it was declared that the importation and sale of French goods in England was a common nuisance, and Parliament enacted that a long list of articles should be prohibited from importation. Upon the repeal of the measure in 1685 , a marked increase took place in the French trade. In the following year, the English imports from that country amounted to $\mathfrak{E}_{\mathrm{I}, 284,4 \mathrm{I} 9}$ and her exports only to $\mathfrak{E}_{5}$ I 5,228 , which left an "adverse balance"

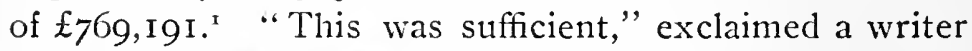
in the British Merchant, "to ruin this kingdom in a few years." = The policy throughout the Stuart period was to develop trade as a means toward the security and power of the kingdom rather than toward the increase of national wealth.

The Revolution introduced a new era in the policy of foreign trade. The bullionist theory gave way to the mercantilistic and the chief aim now was to increase national riches through trade. Trade, as Postlethwayt and Sir Josiah Child observed, should be the chief interest of the nation; its good effects should be judged by its reaction on industry in the increase of the number of workmen and of the nation's capital in commodities. Statesmen should be careful to obtain a favorable balance of trade. ${ }^{3}$ This doctrine formed the basis of the policy of England for more than a century, and was the foundation of the ardent spirit of nationalism that so strongly pervaded

${ }^{1}$ Craik, History of British Conmerce, vol. ii, p. 179.

${ }^{3}$ British Merchant, vol. i, p. I37.

"Postlethwayt, M., Britain's Commercial Interest Explained and Improzed, vol. ii, p. 528 . 
the minds of English statesmen for many decades. Trade was judged by its reaction on industry, and both trade and industry were carefully regulated in order to increase the nation's riches. With this object in view, various encouragements were given to the landowners and manufacturers. New markets were found for English goods, and the colonial system was closely followed. All these objects were followed by Walpole and formed the basis of his policy, the chief aim being to increase the national wealth and to bring riches into the country through a favorable balance of trade.

After the Revolution, the enmity against France increased. In order to cripple French trade, an effort was made to secure a market for English goods in the southern part of Europe. Accordingly, in I703, the famous Methuen Treaty was signed, which secured the entrance of British woollen goods into Portugal duty-free, in exchange for admitting Portuguese wine into England at a lower duty than was charged on foreign liquors. With the Methuen Treaty was put in force the policy of exchanging trading privileges and of securing by treaty new markets for English goods. The Peace of Utrecht is another great example of this policy.

Bacon said he always thought that trading in companies was most agreeable to the English nature.' This appears to have been the belief of the sixteenth and seventeenth centuries, for during this time, whatever trade was carried on by private individuals was considered of secondary importance. As trading companies occupied a prominent place in the commerce of England during the first half of the eighteenth century, it is nec-

'Bacon, Letter to King James, etc., quoted by Craik, History of Brilish Commerce, vol. ii, p. 47. 
essary to pay some attention to their origin and growth. The most important of these chartered bodies was the East India Company. Its charter was first granted by Queen Elizabeth for a period of fifteen years and was renewed from time to time. In later years, many clianges were introduced in its charter, but it did not lose its monopolistic character until 1833 . The strongest rivals were the Dutch, who soon after the example set by the English incorporated an East India Company of their own. Roberts, writing in 1638 , stated that the trade of the English Company did not equal that of the Portuguese or the Dutch, yet in candid fair dealing, the pagans held them in esteem far above their rivals." The English trade increased rapidly, as is shown in a treatise of Sir Josiah Child, who stated in I68I that while the English Company had a greater trade than its rival, the Dutch, the stock of the latter sold at four hundred and fifty and that of the English company at not above three hundred per cent. ${ }^{2}$ In the same treatise, he stated that the importations of the company amounted in 1681 to $£ 600,000$. In a presentation of the East India Company to the House of Commons in 1712 , it is alleged that the conpany exported to the East Indies about $\mathcal{E I}_{150,000}$ of woollen goods and other English products. ${ }^{3}$ James Mill states that from 1708 to 1728 the average annual exportation of English goods to the East Indies was $\mathcal{E}_{92,228,4}$ and that this increased in $x 730$ to I $_{135,484,5}$ and in 1744 to $\left\{231,318 .^{6}\right.$ The same writer says that the average

'Roberts, L., The Map of Commerce, London, 1677, p. 308.

"Josiah Child, Treatise wherein it is demonstrated that the East India Trade is the most National of all Foreign Trades, London, 1681.

Anderson, op. cit, vol. iii, p. 265.

'Mill, J., History of British India, vol. iii, p. Io. 'Ibid., p. 25.

Bloid., p. 84. 
exportation of bullion from 1708 to 1728 was $\mathfrak{f}_{442}, 350,{ }^{x}$

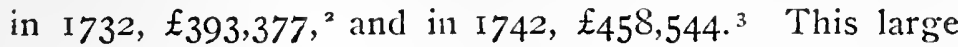
exportation of builion aroused considerable criticism and antagonism to the company.

The imports of the company in I 708 were $£ 493,257,4$ and the average annual importation from 1708 to 1728 was $\mathfrak{x}_{758,042.5}$ During 1730 , goods to the value of $\sum_{1,-}$ 059,759 were brought into the country, ${ }^{6}$ while in 1732 , the sales of the company amounted to $E_{1}, 940,996.7$ This included the thirty per cent. duty paid to the government; a deduction which would bring the sales to nearly the official value of the importation. ${ }^{8}$ The sales increased only a few thousand pounds in value during the following twelve years, and in 1744 amounted to $E_{1}, 997,506.9$ This small gain is due to the fact that the company suffered many losses by the incursions of the native Indian tribes. In 1730, in spite of the opposition of the leading trading centers, the company's charter was continued to $\mathrm{I} 769$; for the company had acquired considerable influence, and its trade was considered to be of great importance to England.

Walpole's policy of protecting English trading interests abroad is seen in the struggle with the Emperor over the Ostend Trading Company. In I7I4, Emperor Charles VI granted commissions to ships trading from Ostend to the East Indies, and eight years later he granted a charter to an East India company at Ostend. Its competition with the English and Dutch companies resulted in a heavy loss to the latter, and as a result brought the Emperor into difficulties with England and

'Mill, J., History of Eritish India, vol. iii, p. ro.

"Ibid., p. 49.

"Ybit., p. 84 .

'Iuid., p. 10.

'Ibid., p. II.

'lbid., p. 25.

' lbid., p. 49.

* rbitt.

"Ibid., p. 84. 
Holland. The Treaty of Vienna in 1725 , between the King of Spain and the Emperor, whereby the former recognized the privileges of the Ostend Company, struck a severe blow at English foreign trade. Now began a long series of negotiations between England, France, and other countries of Europe, to form a confederation against the Emperor and Spain. Commercial motives, both in relation to the Emperor and to Spain, were the guiding principles of these negotiations. By 1727 all Europe was divided into two great camps, the Hanoverian League and the allies of Vienna. Each party made great preparations for war, but after six months of negotiations, terms of peace were signed. The Emperor, among other things, agreed to suspend the Ostend trade for seven years. The Second Treaty of Vienna was signed in I73I between the Emperor, George II, of Great Britain, and the States General of the Netherlands. According to the fifth article the Emperor revoked the charter of the Ostend Company, and declared that no other company from his dominion should trade with the East Indies. He reserved for the said company the privilege of sending two ships to the East, which should return to Ostend and there sell their cargoes. ${ }^{2}$ Walpole thus triumphed in winning a greater monopoly for the English company.

Another chartered company that showed considerable growth during this period was the Levant or Turkish Company. This company in $\mathrm{r}_{5} 8 \mathrm{I}$ obtained its first temporary charter for a period of seven years, and in $\mathrm{I} 593$ a second temporary company was chartered for twelve

'Williams, B., "The Foreign Policy of England under Walpole," English Historical Reviez, vol. xv, p. 696.

${ }^{2}$ Anderson, op. cit., p. 432. 
years. It was not until 1605 that the permanent company was formed. To facilitate the trade with Turkey, Charles II, in 1675 , signed a commercial treaty with the Sultan whereby all former treaties from Queen Elizabeth's time were confirmed; freedom was granted to all English subjects to reside in, and to trade with, Turkey; guarantee was given that English merchants and all others who came under the colors of England might trade with all possible security, and sell and buy all sorts of merchandise not prohibited, not only in Turkey, but likewise in Muscovy. ${ }^{3}$ Six years later, the Turkey Company in a complaint to the King's Council concerning the importation of raw silk by the East India Company, alleged they exported yearly $\mathfrak{E}_{500,000}$ of English products. ${ }^{2}$ The extent of their trade is clearly seen from a Memorial of the French Council of Commerce, presented to their King in I70I. ${ }^{3}$ The French declare that the English carried on the trade with the Levant with much more advantage than the French on account of their woollen goods being better and cheaper. In 1720 , the Company made a complaint to Parliament against the English traders who carried on a trade with Italy. As a result, an act was passed that prohibited the importation of raw silk and mohair yarn from Asia, except from the ports within the dominions of the Grand Seignior. During the following ten years, the trade increased very rapidly, and in I730 some ten thousand pieces of broadcloth were shipped to the Levant. Owing to the fact that the company imported large quantities of raw silk, and paid for its imports chiefly through exportation of English goods, its trade was considered by the English people as exceedingly important to the nation.
'Anderson, op. cit., p. 49.
${ }^{2}$ Ibid., p. 78 .
"Ibid., p. 209. 
The English merchants had early opened up trade with Guinea and the West Coast of Africa. King James, in I618, granted an exclusive charter to certain merchants to carry on a trade with Guinea. ${ }^{r}$ The interlopers so interfered with the trade that it was not long before the company was dissolved. In I63I, a second company was formed. They built forts and warehouses, but the interlopers again forced the trade open, and during the Civil War their forts were destroyed by rival Dutch and Danish merchants. At the accession of Charles II, American plantations were in sore need of laborers and accordingly, in 1662, Charles incorporated the third exclusive English African Company which undertook to supply the West Indies with three thousand slaves annually. The company erected forts and warehouses and like its predecessor had a great deal of trouble with the interlopers. Its trade was practically thrown open by the Declaration of Rights, yet in 1698 the company was allowed to levy a tax of ten per cent. on all private traders for the purpose, as alleged, of supporting its posts and warehouses. The trade was never a profitable one because the private traders or interlopers were too numerous. Finally, in I730, the state of the company had reached such a low ebb that it was not financially able to support its ports and warehouses, and its property was greatly endangered. It was considered a great advantage to trade, even to that of the interlopers, to have the company's forts garrisoned as a protection against the natives. Parliament was appealed to and gave a grant of $\mathfrak{f}_{10,000}$ annually, to be used for the protection of the company's forts and warchouses on the African coast. The company imported some gold, and this brought it into the favor of Parliament. 
The trading company that attracted by far the most attention during our period was the South Sea Company. The origin of the company was due, as Coxe states, to a project of Harley's to restore public credit. ${ }^{x}$ An act was passed in I7II, which gave the exclusive privilege of trading to the South Seas to subscribers of certain debts of the nation. $^{2}$ The royal charter which incorporated the subscribers of the debts under the name of the South Sea Company, trading to the South Seas and other parts of America and encouraging the fishery, was dated the eighth of September of the same year. ${ }^{3}$ Harley accomplished his purpose of securing funds for current expenses and restoring, to a certain degree, confidence in the public credit. The act itself was regarded by friends of Harley as his masterpiece, but we must agree with Anderson that it was almost wholly borrowed from an act of William III for doubling the capital of the Bank of England.4

In the terms of peace with Spain, Harley expected great concessions of trade with Spanish America. At first the British minister demanded free trade with that country, but this was an impossibility. The privilege obtained was known as the Assiento Contract, which granted to Queen Anne the right of introducing negroes into several parts of the Spanish dominions in America, at the rate of four thousand eight hundred yearly for the space of thirty years, from the first of May, 1713, on the same conditions that the French company had formerly enjoyed. The Spanish King also granted to the English

'Coxe, Memoirs of Sir Robert Walpole, vol. i, p. 218.

${ }^{2}$ For full details, see Anderson, op. cit., pp. 258-26r .

${ }^{3}$ MacPherson, op. cit., vol. iii, p. 2 r.

${ }^{1} 8$ and 9 Wm. III, c. 19; also Anderson, op. cit., p. 26 r 
Queen the privilege of sending annually a ship of five hundred tons burden to trade with Spanish America, but the King reserved one-fourth of the profits, as well as five per cent. on the other three-fourths. ${ }^{\text {I }}$ At a general meeting of the company held on the second of June, I713, the members were informed that the Queen had presented to them the Assiento Contract, and had procured for the company two licenses from the King of Spain for two ships of six hundred tons each, in addition to the annual ship, to trade the first year to the northern ports of the Spanish West Indies. The Queen lent them two of her own ships for the first voyage. These concessions aroused great jealousy between the Spanish and the English traders and were the cause of the strained relations existing until the middle of the century between the two countries.

Two years later the company's first ship was launched, but her first voyage was not made until I717. In 1716, the English minister at Madrid concluded a treaty, by which the annual ship, from I7I7 to 1727 , should be of six hundred and fifty tons burden. In I7I8, war broke out with Spain, and all the company's possessions in the West Indies were seized and detained, contrary to the terms of the Assiento Contract, whereby they ought to have had eighteen months allowed them. ${ }^{3}$ The company lost over $£ 200,000$, and their trade was ruined. ${ }^{4}$ On the thirteenth of June, I72I, peace was concluded with Spain and the Peace of Utrecht was confirmed. The South Sea Company was restored to the exercise of the Assiento Contract and the full value of all that had been seized was refunded to them.

1 Anderson, op. cit., p. 273. ${ }^{2}$ MacPherson, op. cit., p. 45.

${ }^{3}$ Anderson, op. cit., pp. 305 and 306.

'MacPherson, op. cit., p. 63. 
The company, in 1724 , resolved to engage in the Greenland whale fishery. Twelve ships were ordered to be built and made ready for the following year. The ships were sent to Greenland, and returned with twentyfive and a half whales: '- not a very profitable voyage, but the most successful of the eight in which the company engaged. They carried on the fishery at a loss until 1732, when they sold their ships and gave up the enterprise with a net loss of $\varepsilon_{I} 77,782 .{ }^{2}$ They were not able to compete successfully with the thrifty Dutch, who were at this time the great whale fishers of the world.

Parliament in 1727 gave the company, with the license and consent of the East India Company, the right to take negroes from the Island of Madagascar to Buenos Ayres. This same year, a treaty of peace between the Emperor and the King of England was signed, and Spain was left almost alone. The possession of Gibraltar by the English and the English trade to Spanish America had long been a source of grievance to every Spaniard. Without even a declaration of war, Spain laid siege to Gibraltar and seized all the effects of the South Sea Company in America. On the signing of a preliminary convention at Pardo near Madrid, on the sixth of March, 1728, peace was restored. It was agreed that England should withdraw her fleet from the coast of Spain and from the Spanish West Indies, and Spain should raise the blockade of Gibraltar and restore the commerce of the South Sea Company with Spanish America, according to the Assiento Contract. It was further stipulated that contraband trade, and other causes of complaint which

\footnotetext{
${ }^{3}$ When two ships strike the same whale, it is divided equally between them.
}

'Anderson, op. cit., p. 44I. 
the Spanish had, should be considered at a future congress. As a result of the proceedings of the congress, there was signed in November, I729, the famous treaty of Seville, by which England, France and Spain renewed all former treaties of peace and friendship. Two separate articles expressly stipulated that the treaties of peace and commerce signed at Utrecht, between Great Britain and Spain, should remain in full force and vigor.

The Court of Spain, in 1733 , proposed to the South Sea Company to pay them, during the remainder of the company's time, two per cent. on the returns of the flota and galleons as an equivalent for their ship. After a long debate in the general courts of the company, the decision as to the offer was postponed. ${ }^{x}$ The following year, a careful investigation was made of the Assiento trade with America; it was shown that the total profits amounted to $\mathfrak{E}_{32,260} \mathrm{I} 8 \mathrm{~s}$., and many were eager to accept the offer of the Spanish King. The majority claimed, however, that the illicit trade had been exceedingly lucrative, and opposed the acceptance of the Spanish offer. ${ }^{2}$

In November, I737, the Jamaica merchants petitioned the King for protection against the seizures by Spanish ships in American waters. They said that the Spaniards not only stopped and searched, but forcibly seized their ships on the high seas, inhumanly treated their commanders, and condemned their ships and cargoes as prizes. This the merchants claimed was a direct violation of treaties existing between the two countries. The King promised them redress on condition that they made good their charges to the Privy Council, and this they afterwards did. On the other hand, the Spaniards had

'Anderson, op. cit., pp. 458-460.

'Ibid., p. 468 . 
equally serious grievances against the English merchants in America. According to the treaty of I670, English ships were not to trade or resort to the coast of New Spain and its adjoining Spanish provinces, unless driven thither by storm. The Americans, nevertheless, carried on a very profitable illicit trade with Spanish America, and there is not the least doubt that a large majority of the seizures they complained of were justifiable. The inhuman treatment mentioned above was, we venture to say, no harsher than that accorded to the Spaniard caught by an English trader.

Following the petition of the American traders, the House of Commons, in 1738 , asked the King to obtain full satisfaction from the Spanish court, and the House of Lords resolved "that the Spanish searching our ships on the open seas, under pretence of their carrying contraband or prohibited goods, is a violation of the treaties subsisting between the two crowns." Strong remonstrances were made to the Spanish court, and as a result the King concluded a preliminary convention, which stipulated that two plenipotentiaries on each side should meet at Madrid to adjust the differences; that the damages demanded by the Spaniards from the English, due to the confiscations in trade, should be placed against the counter-charges made by the English against the Spaniards, and to settle the matter, the King of Spain should pay to the King of England the sum of ninety-five thousand pounds sterling, as a balance due to the English crown and subjects; that this reciprocal discharge did not extend to differences existing between Spain and the South Sea Company, nor to any private contract between either of the two crowns or their ministers with the subjects of the other. ${ }^{\prime}$ The people, much aroused over ex-

${ }^{1}$ MacPherson, op. cit., pp. 218-220. 
aggerated tales of Spanish cruelties, declared England had been too lenient. Lond murmurings were heard against Spain when it was known that the Spanish King, as a preliminary condition to his ratifying the convention, reserved to himself the right to suspend the Assiento, in case the South Sea Company did not pay within a short time the sum of sixty-eight thousand pounds sterling, which it was claimed the company owed for duty on negroes and the King's share in the profits of the ship "Royal Carolina." " These demands were considered at a meeting of the company held on the first of March, I739, and it was resolved not to pay the same, unless the King of Spain accounted to them for all the seizures and captures of their ships and merchandise, which he had not returned to them, although he had agreed to do so. The King of Spain allowed only four months to elapse, in which time he was to pay the ninety-five thousand pounds, and on pretext of the South Sea Company's failure to pay the sum which he demanded, ordered seizures of all ships and goods of English subjects, wherever they could be found in his dominions or elsewhere. As a result of this action, the English people demanded war, and Walpole, on the nineteenth of October, I739, was forced to declare war against Spain.

The illicit trade carried on by the English merchants with Spanish America was exceedingly profitable, and this is the reason why Walpole paid little heed to the exaggerated reports of Spanish cruelties, and used every possible means to keep on friendly terms with Spain. He knew that a war would affect not only this trade, but the entire foreign trade of England. When war did come, England paid dearly for it in the loss of her trade.

'Anderson, op. cit., pp. 489-49I. 
The average annual value of the English exports for the last three years of peace: 1736, 1737 and 1738 -was

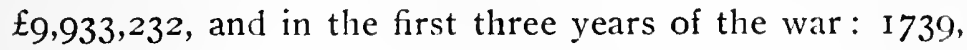
1740 and $174 \mathrm{I}$-it decreased to $£ 8,870,499 .{ }^{3}$ This represents a loss of $\mathfrak{E}_{3}, 188,199$, in return for which nothing was gained. When the effect of the war is thus seen, we are convinced that Walpole's policy of peace was the one best adapted for the welfare of the country.

Throughout the period, the South Sea Company had been the cause of much trouble. It was the chief source of the many misunderstandings with Spain and its trade was not very advantageous to England. Its fishing enterprise, though carried on for eight seasons, was given up as a failure. Many of those most experienced in commercial affairs regarded the company as a chimerical project, and ruinous, rather than beneficial, to the national traffic. Had the company put its original plan into execution, it would have yielded a profit to the kingdom, but the sencing of a single ship, under such limitations, was far from a benefit in point of trade. Cadiz and Seville were, before the company was established, places where the merchants trading to the West Indies got their goods. Many commodities of English manufacture forced their way through these ports to Spanish America. After the Treaty of Utrecht and the sending of the annual ship, the merchants were in such uncertainty that they declined to deal in English goods. The South Sea Company had therefore, by this means, been instrumental in lessening British exports to the West Indies, and had turned the trade, which had previously been very beneficial to many merchants, out of its former channels. If the annual ship lessened British exports to Spanish

${ }^{1}$ Craik, British Commerce, vol. ii, pp. 201-202. 
America, and was thus of no advantage to England, the Company's trade in general must have involved a loss, because the Assiento for negroes was admitted by the Spaniards to be a losing contract, and it was for this reason that the King of Spain allowed the sending of an annual ship to the West Indies. If the commerce of Great Britain to Spanish America had continued for some time to be turned out of its channels, it is hard to estimate the loss that would have resulted. The statesmen of England however, knew that for a series of years the company had greatly irritated the Court of Spain, and as a consequence the trading concessions of the company were annulled by the Treaty of Madrid in 1750. ${ }^{\text {T }}$

No branch of trade showed greater development than that with the American colonies. One of the chief sources to which English commerce owed its steady and gradual expansion throughout this period was the growing importance of her American possessions. From the Navigation Acts, England had with great care followed the policy of the colonial system. In spite of the many legislative acts that aimed to direct the industry of the colonies to the production of raw materials for English industry to manufacture, the colonies grew very rapidly. In the report of the Board of Trade on colonial commerce, made in September, I72I, it was stated that the colonies yielded in favor of Great Britain a yearly balance of $\{200,000$, and on a fair estimate, they gave employment to one-quarter, perhaps one-third, of the whole navigation of Great Britain. As a result of these figures, a colonial agent sarcastically remarked, "London had arisen out of the plantations and not out of England." The policy of Walpole was in strict accordance with 
the colonial system. Many regulations were passed, but they chiefly remained on paper, and but little notice was taken of them. It was to this laxity that the colonies owed their great industrial and commercial growth. The evasion of the laws of trade enabled them to secure the money to pay for the British manufactures and European merchandise annually received from England. None of the colonies north of Maryland ever had balances in their favor. Their obligations to England could be met only by the revenue of the illicit trade carried on with foreigners, whence they derived most of their specie, suitable for payment to the English creditors. The clandestine trade, therefore, benefited England as much as it did the colonies. Lord Sheffield admitted that between $I 700$ and $I 773$ the colonies had by this trade remitted to England upwards of thirty million pounds sterling, in payment for goods taken from her, over and above the direct remittances in produce and fish.

Some valuable information concerning the colonies is contained in a pamphlet entitled The Importance of the British Plantations in Amcrica to this Kingdom considered, published at London, I73I. The author states that Pennsylvania employed in her trade six thousand tons of shipping, and built annually for sale two thousand tons, and that her purchases from England amounted to not less than one hundred and fifty thousand pounds annually. New York was considered of equal importance to the mother land, while Massachusetts employed some forty thousand tons of shipping in the foreign and coasting trade, about half of which traded to Europe. She exported two hundred and thirty thousand quintals of dried fish, and carried on a prosperous whale fishery. The New England states imported from England goods to the value of four hundred thousand pounds annually 
and Virginia and Maryland sent to the mother country fifty thousand hogsheads of tobacco valued at three hundred and seventy-five thousand pounds.

Carolina was the most important of the Southern colonies. According to the Custom House entries, from March, I730, to. March, I73I, there sailed from Charlestown two hundred and seven ships, and during that year .there were exported 4I,757 barrels of rice. ${ }^{1}$ Two years later the rice from this colony supplied the markets of Spain and Portugal and completely excluded the Italian and Egyptian product. By 1739 , the exportation of rice had increased to $7 \mathrm{I}, 484$ barrels, and during the same year the colony exported two hundred thousand feet of lumber. ${ }^{2}$ In 1734 , the Board of Trade made a report on the commerce of the West Indian Islands. They stated that all of the English islands produced, on an average, eighty-five thousand hogsheads or one million two hundred thousand hundredweight of sugar, and that the value of British manufactures annually exported thither was about two hundred and forty thousand pounds. ${ }^{3}$

The total trade of England during this period shows a noteworthy increase. In 1720 , the total exports were

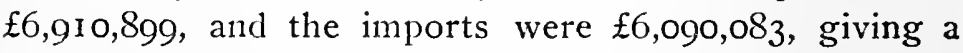
favorable balance of $£ 820,816.4$ By the year 1738 , the

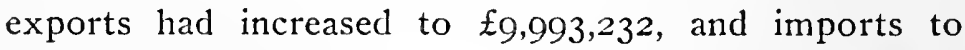
$£ 7,273,5^{1} 3$, giving an excess of exports of $£ 2,719,719 . .^{5}$ Thus during the peaceful years of the administration of Walpole, the annual excess of exports more than trebled,

'Quoted in Postlethwayt, Universal Dictionary of Commerce, vol. i, p. 362 .

${ }^{2}$ Anderson, op. cit., p. 493.

"Quoted by MacPherson, op. cit., p. 200. 'Ibid., p. 116 note.

${ }^{3}$ Chalmers, Comparative Estimete, table, p. 315. 
which, at that time, we must consider remarkable. This increase in trade had a marked effect on shipping. A pamphleteer, in 1739 , said that before I7 I8 the foreign trade was confined chicfly to London, Bristol and Liverpool, but had then become so general that there was not a seaport, and scarce an inland town in England, that was without adventurers who exported quantities of goods, and did business directly with most of the trading companies in Europe and America, and that in London alone the number of adventurers had trebled within the last twenty years.' During I723, a tonnage of 419,683, of which 27,040 tons were foreign, with a value of cargoes of $f 7,395,908$, cleared outwards $;^{2}$ while in 1738 this increased to 503,568 tons, of which 26,627 were foreign, with a value of cargoes of $\$ 9,993,232.3$ In the short period of fifteen years, the tonnage increased 83,885 tons, and cargoes $£ 2,597,324$, while the foreign tonnage decreased $4 \mathrm{I} 3$ tons. Yet in 1738, Lord Lyttleton, in a pamphlet, deplored the state of English manufactures, ${ }^{*}$ and in the same year Richardson wrote his essay on The Causes of Decline of Foreign Trade.

The great trading interests required the protection of a navy. The royal navy in 1720 had one hundred and eighty-two ships of line of battle, carrying 9,940 guns, ${ }^{5}$ and in I739 on the outbreak of the war with Spain the navy had been increased to two hundred and forty-two ships. ${ }^{6}$ According to Mr. Wood, the naval tonnage of

'The late Improvement in Trade, Navigation and Manufactures, London, 1739 .

${ }^{3}$ Chalmers, op. cit., p. 106.

${ }^{3}$ Ibid., p. II4.

'Consideration of the present State of Affairs, 1738.

'Burchet, Naval History, I 720, quoted by MacPherson, op.cit., p. 15.

- Chalmers, op. cit., p. II8. 
1721 amounted to 158,233 tons: ' by 1727 this had increased to 170,862 tons, and in 1741 to 198,387 tons." We notice, therefore, a steady increase in the strength of the navy that was destined in later years to be the mistress of the seas and the pride of the world.

Walpole, from the beginning of his administration, pursued a policy looking toward the expansion of English commerce. Peace was to be retained at any price, and many slights on the part of Spain were overlooked in order to avoid a war that would interfere with trade. The large trading companies were encouraged and protected. At home care was taken to secure raw materials as cheaply as possible, to manufacture at a low cost, and to produce goods of a high standard, so that the English manufacturers could successfully compete in foreign markets. In order to have a fleet of merchant vessels flying here and there in all parts of the world without molestation, it was necessary to have a powerful navy. It was Walpole's policy gradually to increase the royal navy, and we have here the foundation laid for the fleet that later commanded the seas. The policy, in its essence, was mercantilistic to the core. Commerce, industry and agriculture were encouraged in order to secure a favorable balance and increase national wealth. It was, therefore, the age of nationalism. Walpole's efforts to increase national wealth were successful, and won for him praise from statesmen like Pitt, Peel and Gladstone.

\footnotetext{
'Wood, Survey of Trade, p. 55.

"Chalmers, of. cit., p. Ir8.
} 


\section{CHAPTER VIII}

\section{England's Debt to Walpole}

The administration of Robert Walpole, from the economic as well as from the political point of view, is one of the most interesting epochs in English history. Gneist says that since the beginning of parliamentary rule there have been but few periods in which the permanent direction of state policy was clearly and firmly defined. One such case was the consolidation of parliamentary rule under the Hanoverian dynasty during Walpole's ministry, and another was the contest against the French Revolution under the Pitt ministry. ${ }^{x}$ As Walpole had a definite aim in his political measures, so he consistently followed a well-defined economic policy, the underlying principles of which were to put on a sound basis the finances of the kingdom, to stimulate commerce, and to encourage manufacturing.

The one great goal of his political policy was to establish the Hanoverian dynasty securely upon the English throne. He realized that so long as there was a Pretender the country had to be kept in quietness. The quickest way to win over a dissatisfied people is by industrial and commercial prosperity. This secured, the people will not seek change. Hence, so long as the prosperity reigned, he was satisfied, because it was winning over the dissatisfied Tories to the side of the Han-

${ }^{1}$ Gneist, R., History of the English Parliament, p. 353. 207] 
overian King. In this Walpole was successful, as was shown by the fact that when the Pretender did come, in 1 745, very few in England answered the call to arms.

The finances he found in a confused and unsatisfactory state, while public credit was at a low ebb and many doubted whether they would ever receive payment for their loans. Walpole knew that a great step toward gaining confidence in the new government would be taken if a guarantee could be given for the payment of the national debt. In his sinking fund, he was the first English statesman to take measures to reduce the national debt, and by so doing, to restore confidence in the government. Throughout his administration various reforms were effected, and when he resigned, England's finances were on a sound basis and public credit had reached the highest point in the eighteenth century.

Peace, in $\mathrm{r}^{\mathrm{r}} 3$, was dearly bought, but it stopped the drain of wealth and gave to the country an additional supply of labor. If this labor could be industrially used, it would soon produce great wealth. It was Walpole's policy to assist the different branches of industry in order to utilize this great amount of labor and add to the country's wealth. Trade and manufactures were fettered by high duties on the exportation of the finished articles and on the importation of raw material. Competition had become so keen in foreign markets that in order to enable the English trader to compete with his foreign rival, he must not be hampered by a duty. In order to place the English producer on a more equal footing with his foreign competitor, he at one stroke repealed the export duties on nearly all English goods.

Walpole was guided by the mercantilistic maxim that England must sell more goods to foreigners than she consumed of theirs in return. In order to have the 
favorable balance of trade, the English manufacturer had to produce as cheaply as his foreign competitor, if not more so. Every assistance had, therefore, to be given to the producer. The repeal of duties, however, was an innovation, and care had to be taken not to arouse antagonism. The people were much opposed to export duties, so that they were abolished without any criticism; but with import duties it was different, and great caution was necessary. For any reform to succeed, the time must be ripe for its acceptance. A financier may know what ought to be done, but if public opinion does not favor his policy, he will accomplish little. His efforts, however, are not lost, because they may, like those of Walpole, give valuable assistance to the future reformer. Since the reform in the tariff was to the people an innovation, Walpole was cautious in the repeal of import duties. Although the duties on certain dyes and on a few colonial products were abolished, this policy was not pursued energetically and only a few other duties were repealed. He knew what would be best for the people, but he realized that without public opinion strongly in favor of such reforms a serious opposition would be aroused.

Walpole wished to make England a great manufacturing and trading nation. Every encouragement was to be given to stimulate industrial growth and prosperity. The favorable balance of trade depended, as the mercantilists thought, on the excess of exports over imports. Accordingly, free materials and cheap labor became the cry. The people thought cheap food the first essential to cheap labor, and it was Walpole's policy to repeal the duties on all necessaries of life and to tax luxuries. The defeat of the excise scheme, however, put an end to Walpole's reform of the tariff. He regarded the tariff 
not as a source of revenue, but as an instrument to direct industry. Had public opinion been favorable to his plan, we should have had a revolution in the tariff, which would have been reconstructed with the aim of stimulating industrial growth.

f Walpole was a firm believer in the colonial system. The colonies existed to produce the raw materials for the mother country to manufacture. They were discouraged from manufacturing, and were not to compete in foreign markets with English goods, while their own markets were to be secured for the home producer. Certain trading privileges were extended to the colonies in rice and sugar, articles of home growth, that did not compete with English goods in the European markets. The passing of the Molasses Act (I733) must not be overlooked, as it clearly shows that the home government little understood colonial conditions. This and the many other restrictive laws that were enacted would, if enforced, undoubtedly have provoked resistance. The good luck of the colonies lay in the lack of interest taken in them by Newcastle. Acts were passed but not enforced, so that the American plantations were almost left to themselves. It was this laxity that caused the phenomenal increase in colonial wealth.

Many of the restrictive measures were put on paper to please the rich traders and the wealthy manufacturers. In order to arouse little antagonism, it was Walpole's policy not to be strict in the execution of laws and to pay little heed to their infringement. Walpole thus succeeded in satisfying two powerful factions and at the same time did not materially interfere with colonial trade. To some this might appear to be a breaking away from the colonial system. But we must remember that Walpole insisted that the colonies should be a market for English 
goods, should produce raw materials and should not be encouraged in manufacturing. To encourage them in the production of raw materials, many bounties were granted and many duties were repealed. Thus the purpose of the increase in colonial trade and industry was to enable the colonies to secure the means for purchasing English goods. Although Walpole believed that colonial trade and industry should be directed toward stimulating England's industrial growth, he opposed any scheme involving taxation of the colonies by the home government. A project for taxing American colonies was mentioned to him in $\mathbf{1 7 3 9}$, but he said he would leave that for some of his successors who might have more courage than he had and were less friendly to commerce than he was. It had been a maxim with hin during his administration, to encourage the trade of the American colonies to the utmost extent. Accordingly it had been necessary to pass over some irregularities in their trade with Europe, for the more the colonies were encouraged the greater quantities of English products would be wanted. ${ }^{\mathrm{r}}$

Walpole was much opposed to the extensive system of smuggling that annually defrauded the government of large sums of money. After a careful investigation, he decided that the clandestine trade could be checked either by lowering duties or by making their collection more strict. The first, he was afraid, would raise too much opposition, so he adopted the second. Rigid laws were passed against the clandestine landing of dutiable commodities and the sale of smuggled goods. Tea, coffee, chocolate and cocoa were added to the list of excised commodities. Drastic regulations were enacted 
against fraud in the manufacture and sale of excised articles. Walpole was the first minister to begin an active struggle against smuggling, and throughout his administration he carried on the contest with the greatest energy and vigor. Had his policy been followed by his successors, and his laws enforced, smuggling would have been stopped many decades before it was. Walpole laid the foundation for Pitt's great battle against smuggling and fraud, but Pitt was fortunate in living in a period when such reforms met with public favor.

The government lost a large sum annually by the practice of not redeeming exchequer bills until the whole amount of the loan had accumulated. Walpole's plan to number the bills arithmetically, and have them redeemed as the money accumulated, was a change much needed, and a great step toward the system in use at the present day. Another reform also much needed was a new book of rates. Many articles, as we have learned, were imported that were not mentioned in the old book, and the duty on these was paid according to the values sworn by the importer. The merchant not being very particular as to his veracity, the revenue suffered. Walpole made out a new book, including articles not in the old book, and on its adoption a great amount of fraud was checked. The two books were used until Pitt revolutionized the customs, and their use was no longer needed.

Walpole has been severely criticized for his perversion of the sinking fund. Several indirect encroachments had been made prior to 1733 , but in that year a direct appropriation was granted. During the ensuing nine years of his administration several appropriations were made, the fund was even anticipated and given as security for loans. It was, however, necessary to raise money to meet certain extraordinary expenses. The shrewd financier will 
raise extra revenue with the minimum of resistance, and he must also bear in mind that it is unwise to introduce a tax that excites hostility from a large section of the people. To raise the needed revenue, Walpole had to adopt one of three methods: impose new taxes, borrow, or take from the sinking fund. New taxes would meet with disapproval and arouse opposition. Nothing would be gained by borrowing, and later paying the debt from the sinking fund. Accordingly in the appropriation of the sinking fund for current services, he followed the policy that caused the least opposition and was on the whole most economical for England.

The excise scheme, advanced before the ferment over the revivai of the salt tax had subsided, was certain to meet with great opposition. Walpole had been waiting for a favorable time to introduce his scheme for the extension of the warehouse system, but circumstances forced him to bring it forth at a very inopportune moment. The enemy, by the cry that a general excise was contemplated, aroused the people to the point of rebellion. Walpole made a serious error in connecting the name of excise with his plan. The struggle was a political one, and every opportunity was sought to attack Walpole. The dropping of the scheme marked the beginning of the end of Walpole's career. The enemy had gained many adherents and now constituted a formidable opposition. The numerous pamphleteers took the greatest care to paint the great minister's character in the darkest shades. It is to be regretted that the picture found in these pamphlets is, to a great degree, the one accepted by the historians. It is forgotten that the pamphlets were written by Walpole's most bitter enemies and for the purpose of arousing antagonism. They were purely political, and as such should have no weight in estimating 
a man's true character. The historians have overlooked this fact and as a result WValpole's character has received a blot which will be hard to erase.

The extension of the warehouse system, proposed in the excise scheme, was Walpole's greatest reform. He realized the signal advantage to trade and the important check to smuggling that would result from the compulsory warehousing of commodities subject to high duty. The warehouse system was extended in 1724 , and was perfected in the proposed change in 1733 . If he had been successful, the system would have been extended to other articles and would probably have made London the commercial centre of the world, decades before she obtained that position. The merit of the system was not understood, nor did the majority wish to understand it. The struggle was purely political and personal, not economic and national. Although the time was not ripe for the acceptance of such a reform, Walpole's great work in proposing the change must not be overlooked and he must bé given as much credit as is accorded to the man who was so fortunate as to be prime minister when public opinion was favorable to the extension of the warehouse system. Pitt later expressed his regret that he had opposed the scheme. Tucker praised it and proclaimed Walpole the greatest commercial minister England ever produced. The scheme also drew high encomiums from Adam Smith, and all friends of trade and commerce have lauded it.

Many who have spoken favorably of Walpole's reforms have severely criticized him for his opposition to Barnard's scheme to lower the interest on the national debt. The reduction of the interest in I 727 was Walpole's work, and one would naturally think that he would have been the first to endorse Barnard's scheme. He had, how- 


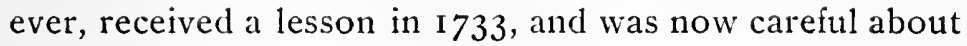
giving his support to any change that would arouse much opposition. At first he was silent, but as soon as he found that public opinion was opposed to the measure, he used all his power to compass its defeat. One must remember that it is the business of the politician carefully to study public opinion and to propose those reforms only that will meet with public approval. If the time is not ripe for the acceptance of any reform, it is folly for a minister to increase the opposition by demanding its adoption. From this point of view, therefore, Walpole was justified in causing the defeat of Barnard's measure.

There is no department of government where ability is more demanded than in that of the finances. It is the financier's duty to find "ways and means" for meeting expenses and maintaining the credit of the government. The unpardonable sin of a finance minister is failure to find money. With every new demand he must devise new expedients, and the new revenue must be raised with the minimum of resistance and the burden placed where it will most easily be borne. The financier must be careful not unduly to disturb political conditions and must avoid arousing any serious opposition. If we judge Walpole by these maxims, we must pronounce him one of England's great financiers. Several times during his administration he had to provide large sums for extraordinary expenses. The ease with which he found the revenue justifies the exclamation of King George I, that Walpole could make gold from nothing. Witl every extra demand for revenue, he was always ready to proyide it, and in a way that did not interfere with the industry or the commerce of the kingdom. In his ability to provide money, Walpole has had few equals in the history of England. 
Walpole, a follower of the mercantilistic school, believed that England had to gain her wealth through commerce and industry. It was his policy to give every possible encouragement to commerce. He fostered and protected the rights of great trading companies, found new markets for English goods, and assisted colonial shipping by granting privileges in cases where the trade did not interfere with English industry. He enlarged the navy so as to protect England's trading interests, and by a system of drawbacks encouraged England's trade in foreign commodities. The climax of his policy was his warehouse system, which if adopted would have quickened England's commercial supremacy. He was a firm believer in the navigation laws and the colonial system, but lenient regarding infringements so long as England gained by the clandestine trade.

Walpole desired to see England the leading nation of Europe. The first essential to power was wealth, and this was to be obtained through industry and trade. Industry was in every way to be encouraged, so that from that source England could obtain a favorable balance of trade. Duties were repealed, new markets were obtained, and bounties were granted to assist English manufactures and farmers. The colonies were assisted and encouraged to produce raw materials, and their markets reserved for the English producer. Drawbacks on exportation of excised articles were paid, and strict regulations guaranteed a high standard of English commodities. Great sailing fleets carried English goods to the markets of the world, and there was scarcely a section of any civilized country in which English goods were not well known and in great demand.

There have rarely been two decades in English history in which the country made such industrial growth and 
enjoyed such prosperity as during the administration of Walpole. Yet this great financier is known to us chiefly in a picture of the darkest hue, painted by the historian who took for his guide the scurrilous attacks of the famous minister's most bitter enemies. When the present writer first became acquainted with the name of Walpole, he too was biased by these unjust criticisms. It is to be hoped that many others also, after a study of his real achievements, will feel ashaned to have believed and accepted the dark pictures of this great man. He was England's earliest able financier, a genius almost without equal in all questions of finance, the first important tax reformer, the first systematizer of dutics and national debts, the first champion against fraud, the father of the sinking fund and one of the most sincere friends English commerce and industry ever had. There is scarcely a branch of England's present financial system which does not owe something to his genius. The more thought a person gives to what he has accomplished the more will he marvel at the consummate ability of the man; and when we realize what a powerful influence his work has exerted in perfecting England's financial system, we feel that England has been fortunate in possessing such a son. To Robert Walpole as minister, financier and diplomat, it is not easy to express England's rebt. 


\section{•}




\section{INDEX}

Aislabie, 45, 52

Amherst, N., 105, 123

Anderson, 39, 42, 187, 190, 192, 193, 195, 196, 197, 198, 200, 204

Anne, Queen, 20, 21, 31, 44, 127, 139, 153, I 95

Annual Register, 2 I I

Atterbury, Bishop, 90

Aylesbury, Bishop, 2 I

Bacon, 189

Barbon, 128

Barnard, 65, 68, 7 I, 72, 74, I I 2, 2 I 4

Bathurst, Lord, 102,105

Boswell, I 22

Brentano, L., 173

British Merchant, I78, I80, I 88

Broderick, 47

Brothers, 178

Brownley, 23, 48

Burchet, 205

Burke, 25, 28

Burnet, Bishop, 40

Cantillon, I 24

Carteret, Lord, 26,66, 102, 103, 104, 105

Caswell, George, 52

Chalmers, 204, 205, 206

Charles I, I 86

Charles II, 187, 193, 194

Charles VI, I9I

Chesterfield, 24

Child, 128, 187, 190

Churchill, 1 I 5

Colbert, 166, 167

Coulthurst, 176

Coxe, 3I, 36, 5 I, 72, 74, 9 I, I I 5, I I 7, I95

Craik, I 88, 201

Craftsman, I 13,123

Cromwell, I 55, 186, I 87

Daily Advertiser, 181

D'Anvers, 123
Davenant, 128, 178

Decker, 92

Defoe, 86,182

De IVitt, 39

Dowell, 95

Drake, 43

Dudley, I 4

Egerton, 158

Elizabeth, Queen, 167, 190, 193

Epsom, I I 4

Ewald, 27

Eyles, 54

Farrar, 35

Gentleman's Magazine, I 76, I81

George I, 31, 62, 87, 2 I 5

George II, 62, 192

Gladstone, 83, 206

Gneist, 207

Godolphin, 21, 22, 41, 42

Gould, 40

Green, 28

Grellier, 43, 62

Hamilton, R., 38, 40, 4I

Hansard, 32, 33, 34, 35, 36, 37, 47, 48 , $50,52,62,63,64,65,66,71,72,73$. $88,89,90,92$, I01, 102, $103,104,105$, IO7, I IO, I I I, I I $2,113,144,115,118$.

I 2O, I $21,123,130$

Harley, 4I, 42, 195

Heathcote, I12

Hervey, 22

Hewins, 173

Historical Register, 32

Hume, 25

Hutchinson, $5^{1}$

Ilay, Lord, IO4

Innocent XI, 40 
James I, 186, 194

James II, 126

Jansen, 49

Jekyl, Joseph, 49

Johnson, 86, 122

Journals of the House of Commons, 35 , $40,45,47,4 \delta, 49,50,51,52,53,62$, $71,73,79,115,116,117,118,130$, $\mathrm{r} 73,175$

Kahm, 164

Keith, $15 \delta$

Keystler, 180

Knight, 5r

Lechmere, 33, 34

Lecky, 36, $3^{8}$

Limerick, Lord, 26

Littleton, 22

Locke, 123, 186

London Magazine, I14

Louis XIV, 167

Lyttleton, Lord, 205

Macaulay, 24, 25

Macliherson, 42, 151, 178, 179, 180, $194,195,196,199,201,204,205$

Mainwaring, 22

Marlborough, 42

Mary, Princess, 82

Mashaw, Mrs., 41

May, 27

McCulloch, 38, 39

Methuen, II 2

Middleton, 47

Mill, rgo, rgI

Montague, 59, 91

Mun, $128,153,155$

Newcastle, 26, 156,165, 210

North, 128, 129

Onslow, 91

Palgrave, 39

Peel, $S_{3}, 206$

Pelham, 26

Perry, I 12 , I 8

Petty, 89,128

Pickering, 91, 141, 143

Pinkerton, 164
Pitt, 41, 49, 83, 119, 120, 135, 206, 21 2, 2 I 4

Plummer, 102, $103,104,123$

Postlethwayt, 186, 188, 204

Price, 41, 62, 68

Prothero, 183,184

Pulteney, 47, 65, 101, 102, II2, II 3 , 118,123

Pym, 93

Raleigh, 43

Rapin, 42, 45, 55

Richardson, 205

Roberts, 190

Rogers, 86

Ross, $5^{\text {I }}$

kushout, 106, 107

Sarheverell, 22

Saxby, 131

Scarborough, II6

Scobell, 89

Seligman, 123

Sheffield, Lord, 203

Shippen, 48, 62

Sinclair, 20, 31, 40

Smith, A., I 20, 2 I4

Smith, J., $176,1_{7} 8$

St. John, 21, 23

Stanhope, 26, 37, 38, 39, 52

Steele, 23

Stevens, 138

Sunderland, $4^{\text {r }}, 53$

Swift, 86

Temple, 86

Thornton, 147,183

Tindal, $35,36,38,39$

Townshend, 24

Tucker, I10, 1 20, 214

Turner, Ir 5

Vanderlint, 123

Walpole, Horatio, 73, 74

Webb, 173

Williams, B., 27, 192

William III, 19, 20, 21, 44, 91, 92, 127. $128,139,153,155,195$

Wirth, 46

Wood, 179, 180, 205, 206

Wyndham, $65,103,112$ 


\section{STATUTES CITED.}

CHARLES II.

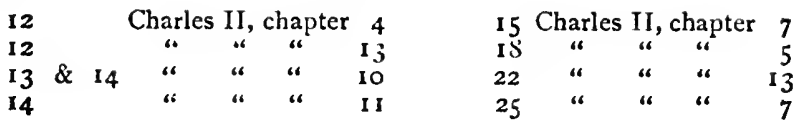

JAMES II.

I James II, chapter 3 I James II, chapter 4

I James I I, chapter I5

WILLIAM ANU MARY.

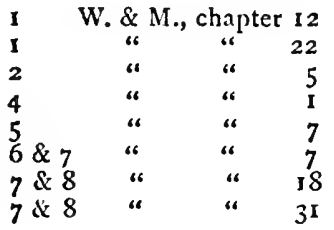

$8 \& 9$ W. \& M., chapter 19

$8 \& 9$

$8 \& 9$ " " 422

9 \& 10 " " 420

9 \& 10 " " 23

$9 \&$ 10 " " 44

$11 \& 12$ " " 3

$\begin{array}{llll}7 \& 8 & & & \\ 788 & & & \end{array}$

II $\&$ I 2 " 40

ANNE.

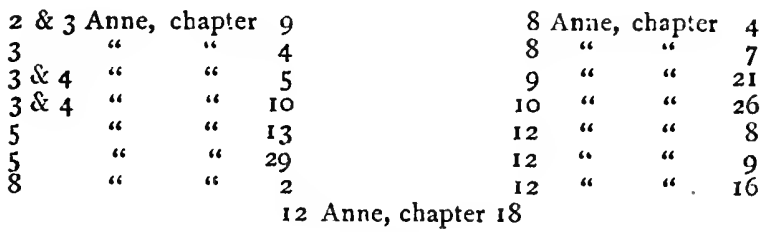

GEORGE $I$.

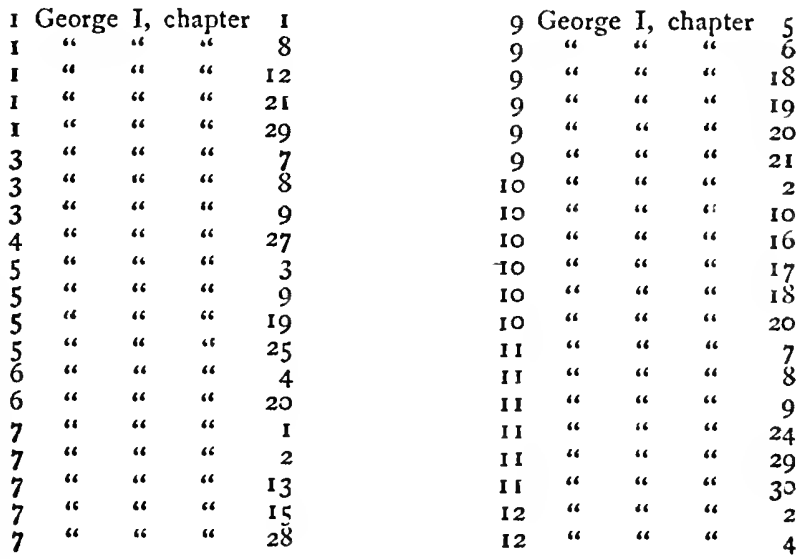


8 George I, chapter I

$\begin{array}{rrrrr}8 & \text { “ } & \text { “ } & \text { “ } & 4 \\ 8 & \text { “ } & \text { “ } & \text { “ } & 7 \\ 8 & \text { “ } & \text { “ } & \text { “ } & 15 \\ 8 & \text { “ } & \text { “ } & \text { “ } & 16 \\ 8 & \text { “ } & \text { “ } & \text { “ } & 18 \\ 8 & \text { “ } & \text { “ } & \text { “ } & 19 \\ 8 & \text { “ } & \text { “ } & \text { “ } & 20 \\ 8 & \text { “ } & \text { “ } & \text { “ } & 21 \\ 8 & \text { “ } & \text { “ } & \text { “ } & 27 \\ 9 & \text { “ } & \text { “ } & \text { “ } & 1 \\ 9 & \text { “ } & \text { “ } & & 3\end{array}$

I George II, chapter I

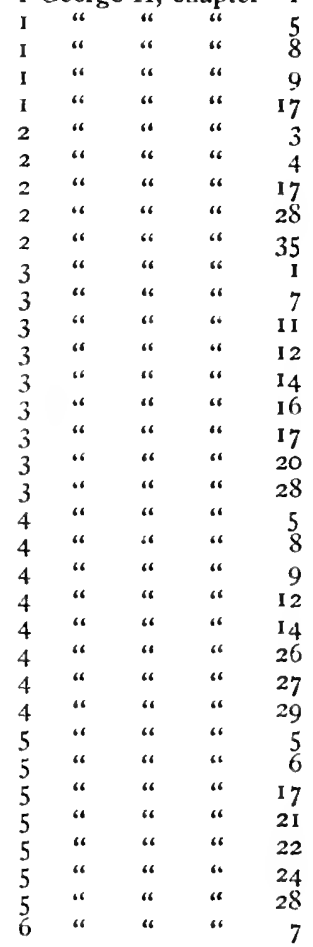

12 George I, chapter 12

$\begin{array}{rrrrr}12 & \text { “ } & \text { “ } & \text { “ } & 26 \\ 12 & \text { “ } & \text { “ } & 28 \\ 12 & \text { “ } & \text { “ } & \text { “ } & 34 \\ 12 & \text { “ } & \text { “ } & \text { “ } & 35 \\ 13 & \text { “ } & \text { “ } & \text { “ } & 5 \\ 13 & \text { “ } & \text { “ } & 21 \\ 13 & \text { “ } & \text { “ } & \text { “ } & 22 \\ 13 & \text { “ } & \text { “ } & \text { " } & 23 \\ 13 & \text { “ } & \text { “ } & \text { “ } & 24 \\ 13 & \text { “ } & \text { “ } & 25 \\ 13 & \text { “ } & \text { “ } & \text { “ } & 26 \\ 13 & \text { “ } & \text { “ } & 27\end{array}$

GEORGE II.

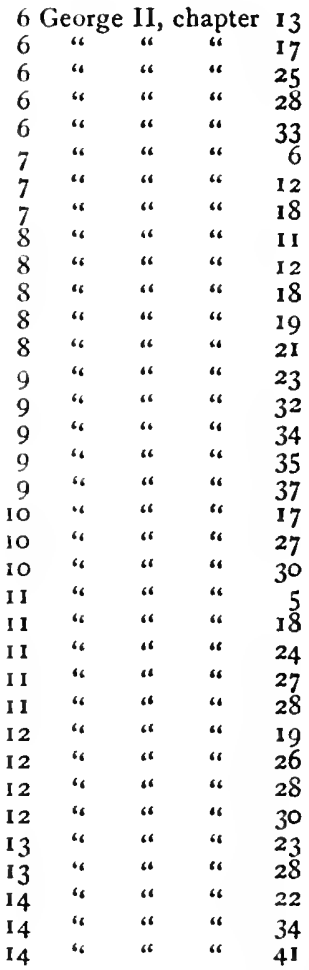

GEORGE II. 


ETURN CIRCULATION DEPARTMENT

$O 202$ Main Library

\begin{tabular}{|l|l}
\hline DAN PERIOD 1 & 2 \\
\hline
\end{tabular}

HOME USE

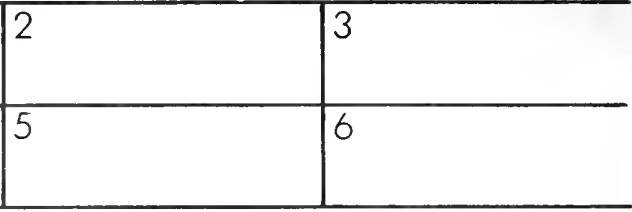

ALL BOOKS MAY BE RECALLED AFTER 7 DAYS

1 - month loans may be renewed by calling 642.3405

0. month loans may be recharged by bringing books to Circulation Desk

Renewals and recharges may be made 4 days prior to due date

\section{DUE AS STAMPED BELOW}

\begin{tabular}{l|l|l}
\hline SFP 27198 & & \\
\hline & & \\
\hline & & \\
\hline & & \\
\hline & & \\
\hline & & \\
\hline & & \\
\hline
\end{tabular}

UNIVERSITY OF CALIFORNIA, BERKELEY JRM NO. DD6, 60m, 12/80 BERKELEY, CA 94720 
I.D. $\operatorname{vin} 4,70(N 5878 \times 4)+18.5$ 
(2)

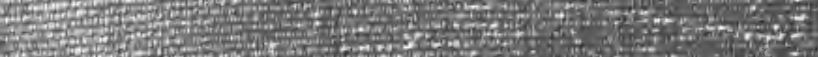

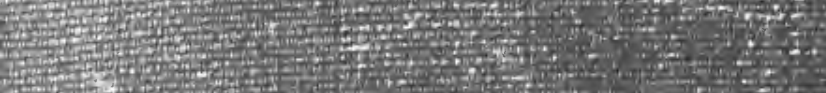
(1) (2)

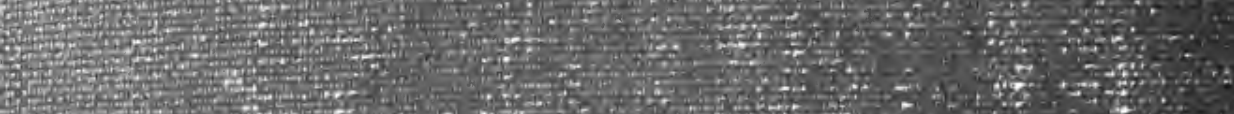

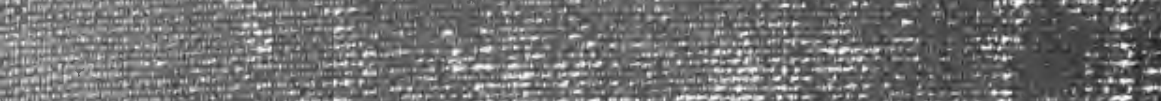

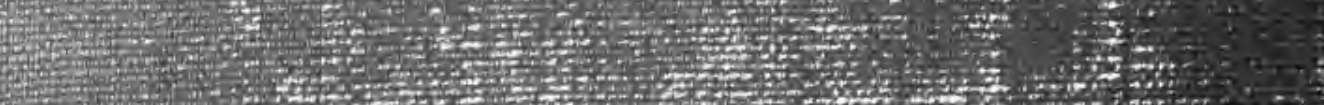
(3)

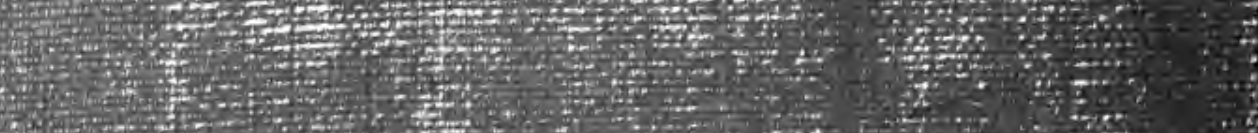

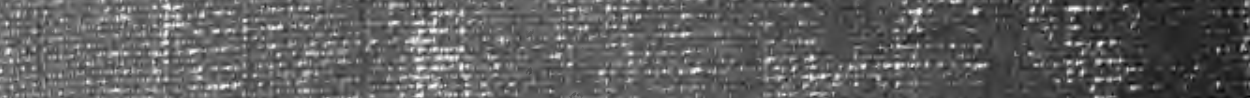

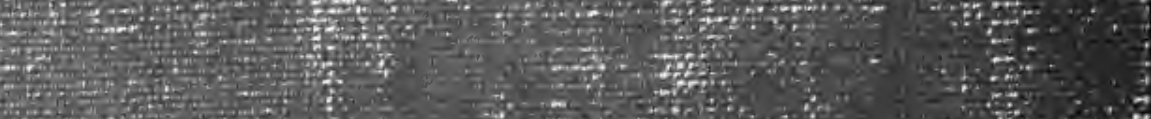

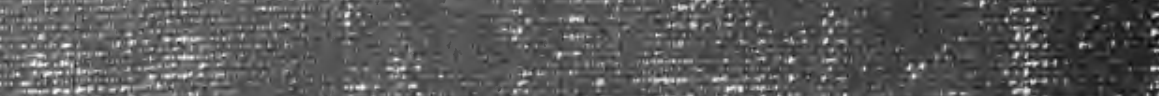
2. (1)

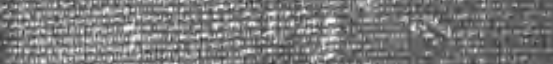
ant

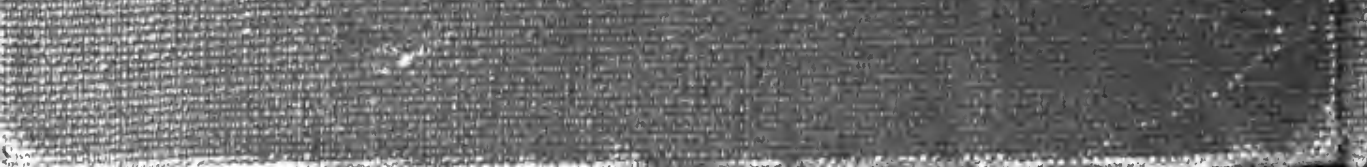

